University of Louisville

ThinkIR: The University of Louisville's Institutional Repository

Electronic Theses and Dissertations

$5-2021$

\title{
A home for friendless women with critical essay "but what was she wearing?"
}

Kelly E. Hill

University of Louisville

Follow this and additional works at: https://ir.library.louisville.edu/etd

Part of the Fiction Commons, and the Nonfiction Commons

\section{Recommended Citation}

Hill, Kelly E., "A home for friendless women with critical essay "but what was she wearing?"'" (2021).

Electronic Theses and Dissertations. Paper 3609.

https://doi.org/10.18297/etd/3609

This Doctoral Dissertation is brought to you for free and open access by ThinkIR: The University of Louisville's Institutional Repository. It has been accepted for inclusion in Electronic Theses and Dissertations by an authorized administrator of ThinkIR: The University of Louisville's Institutional Repository. This title appears here courtesy of the author, who has retained all other copyrights. For more information, please contact thinkir@louisville.edu. 


\title{
A HOME FOR FRIENDLESS WOMEN \\ WITH CRITICAL ESSAY "BUT WHAT WAS SHE WEARING?"
}

\author{
By
}

Kelly E. Hill

B.A., University of Texas at Austin, 2001

MFA, Spalding University, 2013

\begin{abstract}
A Dissertation
Submitted to the Faculty of the

College of Arts and Sciences of the University of Louisville in Partial Fulfillment of the Requirements

for the Degree of
\end{abstract}

\section{Doctor of Philosophy \\ In Humanities}

\author{
Department of Humanities \\ University of Louisville \\ Louisville, Kentucky
}

May 2021 

A HOME FOR FRIENDLESS WOMEN

WITH CRITICAL ESSAY "BUT WHAT WAS SHE WEARING?"

By

Kelly E. Hill

B.A., University of Texas at Austin, 2001

MFA, Spalding University, 2013

A Dissertation Approved on

April 16, 2021

By the following Dissertation Committee:

Professor Deborah Lutz

Professor Susan Ryan

Professor Nancy Theriot

Professor Pamela Beattie 


\section{ABSTRACT \\ A HOME FOR FRIENDLESS WOMEN WITH CRITICAL ESSAY "BUT WHAT WAS SHE WEARING?"}

Kelly E. Hill

April 16, 2021

This dissertation is a historical novel accompanied by a critical lyric essay. Through a combination of scholarly research and creative activity, the novel reimagines the lives of the women who lived as inmates and administrators in the Home for Friendless Women, a charity home that operated in Louisville in the late nineteenth century. The critical essay draws from my interdisciplinary background to combine personal experiences, archival and scholarly research, and literary analysis to connect the U.S. dress reform movement in the 1850s, and its failure to change public perception about what was acceptable attire for middle and upper class women, with the morallyladen vocabulary used after a contemporary woman is raped and she is asked, by law enforcement, by well-meaning friends and family, or by society at large: "But what were you wearing?"

The novel is divided into three sections. Section 1 is set in 1878 and is narrated by Ruth, an Oberlin college student who ends up at the Home after being sexually assaulted by a male classmate. Section 2 takes place in 1889 and is narrated by Belle, a former sex worker. The final section is set in 1901 and is narrated by Minnie, one of the Home's Board members. 
TABLE OF CONTENTS

PAGE

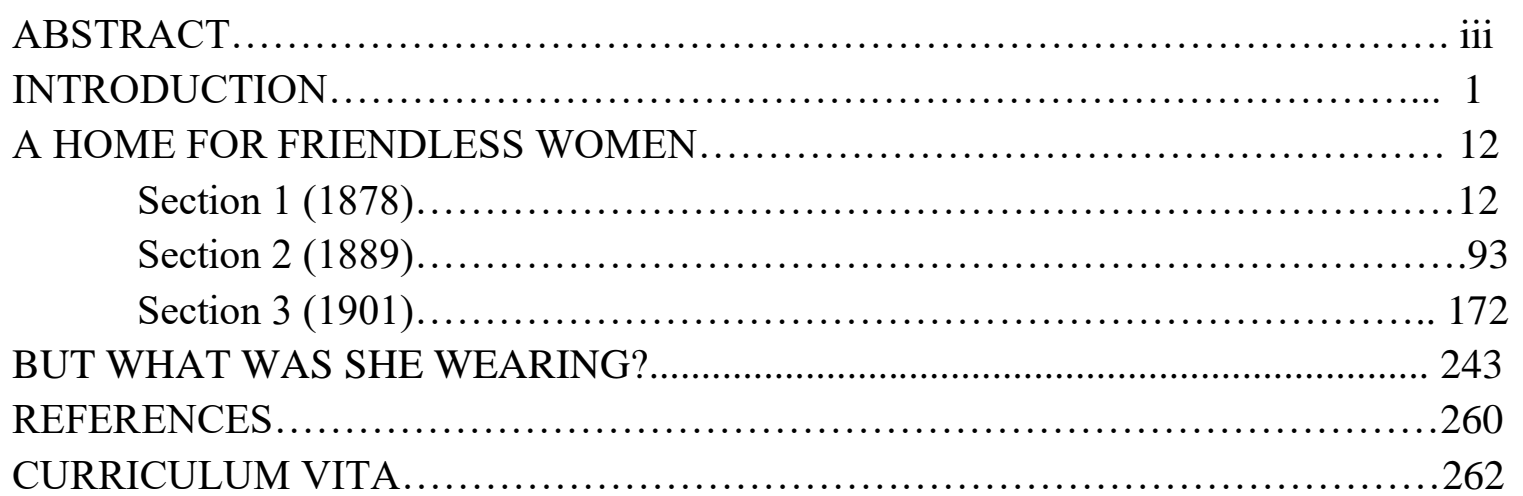




\section{INTRODUCTION}

For my dissertation, the form of the historical novel and the lyric braided essay work in tandem as a feminist project to challenge patriarchal storytelling and situate female-driven and femalecentered storytelling. By utilizing two distinct genres, this work will engage with a wider audience than either alone. My research and utilization of the historical novel and the lyric essay to achieve a more complete feminist restorative justice project to re-center women's experiences will also add to the fields of literary and genre studies.

From the archival research, reading, and coursework I have undertaken since beginning my doctoral work, I have discovered the various ways that American women writers historically challenged, subverted, and re-framed discussions about the lives and bodies of women. There is considerable scholarship on how the historical novel has been activated as a feminist tool to "talk back" to the narrow view of history and canon formation, and one of the most active points of resistance for these writers is the fact that male authorship has dominated the literary canon. In "Distance and Historical Representation," historian Mark Salber Phillips discusses the rise of "micro history" in the late twentieth century. As historians began seeking "closer emotional and ideological identification with the experiences of women... and others whose lives seemed to have been erased from larger-scale narratives," there was a concerted effort to focus on individual stories, especially from marginalized groups. ${ }^{1}$ The desire to better represent marginalized groups has also been reflected in literature. As Cooper and Short note, “[h]istorical fiction has always been a popular genre throughout the history of the novel, one which has often been associated with a female readership, and with traditionally feminine concerns such as love,

${ }^{1}$ Phillips 128 
romance, and domestic intrigue."2 Sir Walter Scott's "reinvention" of the historical novel with Rob Roy and Ivanhoe further cemented the idea in both readers and literary critics that serious historical fiction was the domain of men, and historical fiction by women was historically inaccurate or merely romantic escapism since it was more concerned with the "domestic" sphere of women, rather than the "masculine" sphere of war or politics. ${ }^{3}$ Historical fiction in the past often featured men as active explorers or heroes, with women as passive love interests; this also means that historical female figures were often seen and described through a patriarchal lens. ${ }^{4}$

Historical fiction as a feminist restorative justice project therefore serves several purposes: it reimagines lives for women they never experienced due to oppression or violence; it liberates both the female character and the female writer from patriarchal discourse by allowing a woman writer to create complex female characters; and it alters the discussion around the modern woman and her body by highlighting similarities between representations of women in the past with modern society. A contemporary female writer of historical fiction, writing from a third-wave feminist perspective, can highlight a "shared sense of struggle" with women from earlier generations, while also rewriting "historical and contemporary versions of the female subject." ${ }^{5}$

The historical novel is uniquely situated to rediscover untold stories and is capable of imagining whole lives for groups of people who, due to institutional and social barriers, were denied the privileges and freedom granted the dominant group. The historical novel asks the reader to rethink the past and re-examine events and historical figures, both familiar and

\footnotetext{
${ }^{2}$ Cooper and Short 2

${ }^{3}$ Cooper and Short 2

${ }^{4}$ Cooper and Short 3

${ }^{5}$ Cooper and Short 167
} 
unfamiliar, from the perspective of a marginalized group. ${ }^{6}$ My historical novel blends scholarly research with the compositional tools of fiction, including both linear and non-linear elements of storytelling, in order to tell the story of the women who were inmates and administrators in the Home for Friendless Women. As a feminist writer, I follow the path laid out by previous contemporary women writers who also used the historical novel to re-insert women into the historical record and imagine alternate lives for them.

Similarly, the lyric essay has been utilized in the last several years by feminist writers, specifically Leslie Jamison (author of The Empathy Exams); Eula Biss (author of Notes From No Man's Land); and Aisha Sabatini Sloan (author of The Fluency of Light). In all these lyric essay collections, I was intrigued by the modality of "braiding" as a compositional strategy, how this type of personal essay abandons linear chronology in favor of association through the utilization of images or metaphors. There is nothing inherently natural about an essay that uses time as an organizing structure, although linearity has always been a familiar and reliable storytelling device. By privileging relationships, rather than time, the structure of the lyric essay suggests there are limits to understanding something solely through logic and reason. When writing about gendered notions of power and oppression across generations, for example, there is not a clear beginning, middle, and end to sexist ideology and discourse. Rather, these big ideas are best understood through symbols and comparisons, relying on what Jennifer Sinor calls the "accretion" of meaning through complication, rather than time. ${ }^{7}$

In Breaking the Sequence: Women's Experimental Fiction, Ellen Friedman and Miriam Fuchs examine the work of various women writers, including Virginia Woolf and Joyce Carol

\footnotetext{
${ }^{6}$ Gallagher 20, 24

7 Sinor 194
} 
Oates. The work of both women has been viewed as unconventional, even radical, because of their refusal to follow established conventions, conventions, they argue, set by the male authors who have largely dominated the Western literary cannon. By changing the linearity of a story, an author is not "deny[ing] and dismiss[ing] linear history," but rather adding to it. ${ }^{8}$ Eschewing traditional modes of narrative, which rely on logic and time, aligns a project more closely with a feminine space, and Friedman and Fuchs point out that our ideas about the structure of a story are "surprisingly bound up in our understanding of biological sexual differences," where we associate the logic of chronology with male writing and non-linearity with feminine writing. ${ }^{9}$

Sinor explains in her essay "Deserting the Narrative Line: Teaching the Braided Form" that the strands of a typical braided essay include a present-day storyline which serves as the grounding "through line" of the essay and which often unfolds in a linear fashion; a research strand which offers new ways for both reader and writer to view personal experiences as well as larger institutions via specific images that appear in the other threads; and a past-tense thread that either focuses on childhood memories or specific instances from the past. Much like the research strand, the past-tense storyline is not chronological but rather "archaeological."10

The lyric braided essay asks more of both reader and writer, since it utilizes nonchronological storytelling as well as white space, but it also allows for deeper meanings and connections across time periods to emerge. As Judith Kitchen notes in "Grounding the Lyric Essay":

\footnotetext{
${ }^{8}$ Friedman and Fuchs 261

${ }^{9}$ Friedman and Fuchs 252 . Their arguments linking non-linearity with women writers can also be found in the work of Hélène Cixous and her thoughts about "feminine writing." ${ }^{10}$ Sinor 193
} 
These essays usually focus on a personal experience, so the tenor is known; yet the essay is always also about something else, something to which personal experience merely provides the authority through which the vehicle (often, in this case, an idea) can help reader and writer alike perceive what's at stake. ${ }^{11}$

Similarly, Mark Tredinnick notes in his 2011 online essay "The Lyric Stance: Voice, Place and the Lyric Essay," an essay "trades in facts" and rather than attempting to recreate a moment in time, the lyric mode offers an experience to the reader and asks the reader to make sense of it too, to help shoulder the burden of the past and create meaning not from linear storytelling but from associative images. Here it's the weight of history, rather than the passage of time, that creates meaning. The gaps and spaces and blanks often found in the lyric essay makes the essay an art form, Treddinick argues, "[i]n part by asking the reader to step toward it and piece together a narrative, which becomes the reader's narrative, not merely the writer's."

Virginia Woolf writes in A Room of One's Own that there is a shared language male critics have employed across generations to disparage women seeking intellectual achievement. About this familiar chorus of male criticism, Woolf wryly notes, "So accurately does history repeat itself." 12 Part of the power of the lyric essay, then, is that deliberate repetition, both through word choice as well as the repetition of rhetoric across generations, becomes its own form of resistance and serves to upend historical silencing and dismissal. The lyric essay disrupts the tiresome trope of history repeating itself by reclaiming repetition to create a larger chorus out of an individual story. Through a blending of the personal and historical, the lyric essay works to achieve a kind of healing for both reader and writer. By inserting myself as a minor character

\footnotetext{
${ }^{11}$ Kitchen 119

12 Woolf 65
} 
into a larger story about systemic sexism, both internal and external sources of conflict were revealed and addressed, and my critical essay "But What Was She Wearing?" is a product of my interdisciplinary background. As a PhD student, I have been encouraged to locate and critically assess societal forces of oppression that affect the lives of individuals. This lyric essay allowed me to explore themes that have always gripped and fascinated me, specifically issues of gender. It also gave me space to unite both the personal and the political in storytelling.

The coursework completed during my time in the Humanities program has given me the tools of an interdisciplinary inquiry and a familiarity with literary theory as well as feminist theory, which assisted in the writing of both the lyric braided essay and the novel. In Professor Karen Hadley's class, for example, we read Jane Austen's novels alongside film adaptations of her work, and it became clear that how each film chose to interpret gender norms and social class concerns could not be divorced from the time of their adaptation. This was a very freeing realization and allowed me to stop worrying about how I as a twenty-first century woman and scholar would write convincingly about nineteenth-century women. Instead I saw the benefit of bringing current feminist theory and ideas to bear on the novel since it's frankly impossible to separate myself entirely from my own society.

However, I did want to avoid having my characters behave and speak in a manner that would have been too radical to be believable, and therefore I relied heavily on archival research, specifically old issues of The Courier Journal to better understand the oppression Victorian women experienced. I studied advertisements of patent medicine products marketed to women. ${ }^{13}$

\footnotetext{
${ }^{13}$ Analyzing these ads also led to an incorporation of artifacts into the novel, which helped me develop the world of the characters. It is one thing to read in a book how women in the late $19^{\text {th }}$ century were believed to be weak invalids with delicate constitutions. I understood it in a different way after reading about medicinal cures advertised in the newspaper promising to cure women of their "uniquely female ailments" of derangement, weakness, hysteria, etc.
} 
I read letters to the editor written by women about legalizing prostitution, about the right to vote, about education. I researched how famous female suffragists, artists, and speakers were discussed in the newspaper. These articles gave me a glimpse into the oppression and privilege (white) women at this time experienced. Through a careful reading, I was able to decipher a unique tone in many of the articles written by women, especially those about fashion, a tone that can best be described as "jauntily angry." There was often a barely concealed rage in their words, and once I identified that anger, I felt more confident in my ability to capture nineteenth-century first wave feminist concerns.

Similarly, Professor Hadley's class also introduced me to film theorist Laura Mulvey and her examination of the "male gaze," which I found very helpful while working on this project. Mulvey's theories in "Visual Pleasure and Narrative Cinema" illuminated a problem I was encountering in many historical novels, which was that female characters were often portrayed as little more than beautiful objects to be consumed by powerful men and that even stories that sought to re-center women's experiences were guilty of the "male gaze.” Mulvey discusses the dangerous ripple effects of the male gaze. The obvious problem with objectifying women in film is that men will learn to see women as objects; less obvious is the impact this has on how women view other women, as well as themselves. Creative writers, even those seeking a feminist perspective in a novel, are not immune to the pressures of socialization; reclaiming marginalized historical figures is much more complex than simply making a woman the protagonist of a historical novel. In my own creative work, I had to be mindful to not fall into a male gaze trap as I wrote about the women in the Home for Friendless Women. Historical novels, especially those in set in the Victorian time period, are often preoccupied with how women's bodies were viewed and treated by society. The danger, however, is that over-sexualizing female characters or, 
conversely, creating one-dimensional male characters who are little more than craven and depraved sexual beings who treat women as objects does not provide a feminist perspective; the male gaze, as well as patriarchal discourse, are still present if the medium and the message are not both working as feminist tools, which is why I believe that both the historical novel and the lyric essay are crucial components of the project.

Initially, I thought my lyric essay would address out of wedlock motherhood or the idea of "fallenness." However, much like the lyric essay I wrote in HUM 654 under the guidance of Professor Kristi Maxwell, my ideas evolved organically. For HUM 654, I planned to juxtapose the discourse surrounding today's \#MeToo movement with the harassment Victorian women faced. However, after seeing the Women Artists in Paris 1850-1900 exhibit at the Speed Museum in May of 2018, I was struck by the work of Paula Modersohn-Becker and her paintings of pregnancy and nursing mothers, especially after reading about her long-standing desire to be a mother and early death after childbirth. Once I started researching Modersohn-Becker, I realized the exhibit had excluded notable details of her life, including that she was the first female Western artist to paint herself nude and that she had left her husband for a period of months to focus exclusively on her art. Over the following summer, the threads of my own lyric essay emerged: (1) a meditation on Modersohn-Becker's art and life (2) a discussion of hysteria in the nineteenth century and the ways this long-debunked diagnosis impacts modern women (3) an examination of my own experiences with systemic sexism in medicine, and how these interactions intensified once I became a mother. In my many revisions of the essay, Professor Maxwell pushed me to combine critical theory, personal experience, and research, which also prepared me to write the lyric essay for my dissertation. 
I attempted to write a critical essay that engaged with motherhood, but it became clear after several frustrating weeks that it was too deeply grounded in the personal, or as Sinor said, the essay failed to be about anything else. When I was conducting research for the novel, I kept encountering articles about dress reform. ${ }^{14}$ I started remembering things I hadn't thought about in years surrounding my own complicated relationship with clothing: how my first husband used to dislike when I wore short dresses or short shorts and how I could never find the right words to tell him how much that bothered me; the time when I was a high school teacher and a student came into my classroom crying because an older teacher said her costume was inappropriate and she wanted to know what I thought; the time a stranger slowed down his car to shout out his window, Are you wearing anything under that dress?; the time a woman stopped me on the street to compliment my winter coat; the time my female boss in college pulled aside a group of us to tell us our skirts were too short and how she later complimented me when I was the only one to go out and buy a much longer skirt. In other words, I suddenly couldn't stop thinking about my complicated relationship with my clothes, and I quickly realized that a lyric essay highlighting similarities in conversation about respectable dress for Victorian women and contemporary women would certainly be about something else.

For the critical essay, I drew from my interdisciplinary background to combine personal experiences, archival and scholarly research, and literary analysis to connect the dress reform movement in the 1850 s, and its failure to change public perception about what was acceptable attire for middle and upper class women, with the morally-laden vocabulary used after a

\footnotetext{
${ }^{14}$ Likely, I was already subconsciously writing an essay about clothing and was therefore primed to notice these articles.
} 
contemporary woman is raped and she is asked, by law enforcement, by well-meaning friends and family, or by society at large: "But what were you wearing?"

150 years ago, dress reform advocates challenged the idea that respectable women dressed for male attention or approval, rather than their own physical comfort. While twenty-first century women are not hampered by physically restrictive clothing like petticoats or corsets, they are still told to dress with male attention in mind. When a woman reporting an assault is asked about her clothing, the implication is that she is somehow responsible for her own rape because her clothes (too tight, too short, too revealing, etc.) invited unwanted male attention and violence. It was necessary in this essay to juxtapose nineteenth and early twentieth century sources - Charlotte Perkins Gilman's novella Herland, Edith Wharton's novel The Age of Innocence, and a Victorian etiquette handbook, with more contemporary ones - the scholarly research of Amy Kesselman and Carroll-Smith Rosenberg, as well as blog posts, high school dress codes, and an examination of my own thorny relationship with clothing. These seemingly disparate sources revealed startling similarities between Victorian and contemporary women's fights to control their clothing choices and their bodies. In "The 'Freedom Suit': Feminism and Dress Reform in the United States, 1848-1875” Amy Kesselman notes that in the nineteenth century, a woman's dress both reinforced and communicated gender roles, and that by linking a woman's respectability with her clothing, society was able to restrict her physical body and her freedom since movement was difficult in proper attire. ${ }^{15}$ This strict policing of women's bodes via their clothing revealed male anxiety about gender roles and the perceived breakdown of society should women dress for themselves, rather than men. ${ }^{16}$ As Carroll Smith Rosenberg

\footnotetext{
${ }^{15}$ Kesselman 496

${ }^{16}$ Kesselman 508
} 
notes in Disorderly Conduct: Visions of Gender in Victorian America, the physical body is often a proxy for society itself and this leads to a policing of both dress and social decorum norms, where the practices of the social body, as enacted on the physical body, are seen as the "normal" order of society. ${ }^{17}$ Therefore it becomes "normal" to tell women to prevent their own rapes by avoiding "provocative" clothing, rather than telling men not to rape. Until writing this essay, I had never fully examined my own relationship with clothing, and yet once I started allowing myself to examine this, what might have been abstract, both to me and a reader, became startingly concrete. By weaving in my own experiences alongside scholarly research, a more robust conversation emerged about the historical underpinnings of this policing of women's bodies via their clothing.

${ }^{17}$ Rosenberg 51 


\section{A HOME FOR FRIENDLESS WOMEN - PART I}

The Home for Friendless Women minute books - January 3, 1878

- Two women have been sent to City Hospital, one to Insane Asylum, one expelled 
Women beware. You are on the brink of destruction: You have hitherto been engaged in crushing your waists; now you are attempting to cultivate your mind: You have been merely dancing all night in the foul air of the ball-room; now you are beginning to spend your mornings in study. You have been incessantly stimulating your emotions with concerts and operas, with French plays, and French novels; now you are exerting your understanding to learn Greek and solve propositions in Euclid. Beware!! Science pronounces that the woman who studies is lost. ${ }^{18}$

${ }^{18}$ From R.R. Coleman, M.D. as quoted in For Her Own Good: Two Centuries of Experts Advice to Women 


\section{Never make yourself the hero of your own story}

Some of us arrive at the Home of our own volition; others are brought here. I like to make wagers in my head about which girls will crumble under confinement and which will last the full eighteen months. The girl Cora, who arrived last night in the care of a doctor, I think will stay. A girl's outward appearance is not a good indicator of her inner strength, although wrist size is. I have noticed that those with delicate, bird-like wrists rarely last.

Take Louise, who arrived last month claiming to be a married woman of good standing. In her shimmering blue dress, her pale arms no bigger than a child's, Louise said she needed to stay in the Home during her pregnancy because her husband wouldn't leave her alone. Morning,

night, and all the hours in between, she told Matron. She started crying when she said hours. She feared the constant intercourse would lead to miscarriage, as it had three times already. Matron had her doubts but she brought Louise's case before the Board, and they agreed she could stay.

On Louise's first full day in the Home, she complained morning, night, and all the hours in between. The size of her room (But where will I hang all my hats?), the food (Excuse me, I'm missing a celery dish), the gall of being assigned chores (Sew curtains?!) After twenty-four hours Louise decided to return to her husband.

I suppose he's better than no celery dish, I said to Matron as Louise stormed out.

The new girl Cora does not have small wrists but she did forget to light the fire ahead of today's lecture, and the sitting room is bitterly cold. While bright, the fire is not yet hot enough to reach those of us by the drafty windows. As we shiver, Reverend Davidson sweats. Parallel tracks of sweat begin at the crown of his head and race down his cheeks. He swipes ineffectually at his eyes and cheeks with a handkerchief and surveys us, a motley group of women in hardbacked chairs. A captive audience. Subscribers to the Home are allowed to drop by whenever 
they choose. Most prefer to stay for supper but the reverend always takes the opportunity to deliver a lecture.

Rev. Davidson's wife is the current president of the Board. The sitting room is named after her, and her portrait looms above her husband's sweating body. I think she was aiming for mysterious with her small half smile, but with her old-fashioned hairstyle and wide eyes, she looks more mystified than mysterious.

“Let us pray," Rev. Davidson says.

We bow our heads and recite along with him:

Bless the Lord, O my soul, And forget not all his benefits, Who forgives all your iniquity, Who heals all your diseases, who redeems your life from the Pit

"Amen," Cora says loudly, and Mrs. Davidson frowns at her.

Rev. Davidson begins pacing in front of the fire, hands clasped behind his back. "Would the Egyptians have supported woman suffrage?"

Kate reaches over to give my hand a sympathetic squeeze. I have heard three versions of this lecture in the five months I have been here. Would Galileo have demanded that women have the right to vote? Jane Austen? The esteemed George Washington? And now the Egyptians are eager to chime in.

What an odd interpretation of her work, I said to Kate after the Austen lecture. It made me wonder if he'd ever read Pride and Prejudice. 
"I do not claim to be an expert on ancient Egypt," Rev. Davidson says. "But study and analysis of a culture's artifacts reveals much about their attitudes and beliefs. Which is why I have brought curiosities from the ancient world."

Mrs. Davidson passes him a small wooden box with a brass handle, placing it carefully on the table before him. He makes a show of opening it. Maggie stifles a yawn, Cora shifts in her seat and cranes her neck to see better, and Kate absently rubs a hand across her belly. Behind us, in a row by herself, sits Theresa. She hasn't spoken a word since her twin sister Catherine died last month. I don't know if she avoids us or if we avoid her and her palpable, frightening grief. Sometimes she will look at us with eyes so blank and wide, it's easy to think she is the one who died and we are the earthly voices calling out to her. If Matron did not remind her, I doubt she would remember to comb her hair. Theresa and Catherine shared the same blonde hair and large brown eyes. Catherine was left-handed though, which Maggie said was a sign of bad luck, and she's not surprised that the poor girl died the way she did since she was clearly cursed. It was difficult to tell the sisters apart, when Catherine was alive. I would often think of them as CatherineTheresa, a creature out of mythology with one body and two heads. The sisters arrived together, from Ruby Sherwood's bagnio on $4^{\text {th }}$ Street. The things they have seen, the poor girls, Matron said.

Rev. Davidson plunges his hand into the box and holds up a dingy piece of muslin, which he unfurls with no small amount of drama. "Any idea what this was used for?"

The cloth lying limply at his feet looks suspiciously like one of the bandages we keep in the upstairs hall closet, last wrapped around Catherine's arm after she burned herself in the laundry room.

"This was once wrapped around a dead body." 


\section{Cora gasps.}

Catherine is dead, so he's not wrong.

"I was lucky enough to attend an unwrapping party years ago. Something I will never forget."

It's hard to picture Rev. Davidson at a party, much less an Egyptian unwrapping party. Even less likely that he was such an interesting guest that the host gave him, as a parting gift, the very cloth that had been wrapped around a mummy. Imagine the stench of such a cloth! Even though he's waving it about, I don't smell a thing and these days, my stomach turns at the most innocuous of smells.

He rummages in the box again and this time emerges with a blood red scarab beetle pin, identical to one that Mrs. Davidson often wears on her visits. "The scarab beetle was an important symbol to the Egyptians, representing existence and growth. Sometimes they were wrapped up with a body, where they would be a stand-in for the heart."

He walks around the room and holds out his cupped hand for us to admire the pin. When he holds it in before me, I see Mrs. Davidson's initials carved in tiny script on the beetle's hind legs. How interesting, I murmur.

“Can I touch it?” Cora whispers, extending a hand.

"This is priceless beyond measure, young lady."

Rev. Davidson returns to the front of the room where he brandishes more items. The bronze bust of a pharaoh he doesn't name - Ramses, I suspect - and a smudged pencil sketch of a river he says is the Nile. With each item, we clap politely. 
Sometimes I wonder if his lectures are as rambling as they strike me, or if my brain is scrambled from the baby. Maybe the reason Mrs. Davidson looks so puzzled in her portrait is because she was forced to sit through one of these long-winded suffrage talks.

"Now what does any of this have to do with suffrage you might be wondering?" He hands the box to Mrs. Davidson who retreats to the far side of the room.

Mrs. Davidson sets the box on a nearby chair, but then quickly grabs hold of it again. I overheard her tell Matron she musn't be careless with her jewelry or valuables around girls of our class. "They'll snatch the bonnet off your head if you don't watch them," she warned. This must be why she never removes her hat or gloves.

Who in Rev. Davidson's life has him so concerned about women voting? It must be his daughter Minnie. She visited the Home a few weeks ago, and it was quite a shock to learn the Davidsons had a beautiful daughter. Minnie shared her mother's wide eyes but they gave her face an energetic, rather than surprised look, and her reddish hair, the same color as her father's, was twisted up and away from her high forehead in a swirl of curls, rather than plastered to her face with sweat. She had quite small wrists; doubtful she'd last long as an inmate in this place. During her visit, Minnie peppered us with questions: Did we like living in the Home? Where did we live before? Were we still able to wear corsets in our conditions? Mrs. Davidson was so startled by that last question she dropped and broke her teacup, the one with the tiny rosebuds circling the inside rim. It was Matron's favorite but she didn't say a word as she carefully swept up the pieces. When Minnie learned Kate's name, she recited a poem:

O Lady Kate, my cousin Kate,

You grow more fair than I:

He saw you at your father's gate,

Chose you, and cast me by. 
He watched your steps along the lane,

Your sport among the rye;

He lifted you from mean estate

To sit with him on high.

"Do you know that one?" she asked and Kate shook her head shyly. "It's by a woman poet. A poetess?" she wondered. "If that's not a word, it should be!"

After Minnie left, I found a small leather book, deep purple with an impossibly soft cover, in her chair. It was a diary of sorts, where she listed the parties she attended, and the parties she hosted, along with food served (To ensure I never repeat a dinner's menu!) At the back of the book, there was a list of women's names on a page titled Friends, and a list of men's names under the heading Prospects, although some names were crossed out with MARRIED written across them. I didn't plan on keeping the book, but the cover was so soft and we aren't allowed any books and reading about Minnie's parties and menus was like being given a novel. When I feel guilty about hiding the book inside my pillow, I tell myself she likely hasn't even noticed its absence.

“In practice, woman suffrage works a positive moral injury on society," Rev. Davidson says now. "When we study the Egyptians, do we read the writing of an Egyptian Lucy Stone? Do we admire the artwork of those Egyptian women who wanted more than they had been given, when they had already been granted so much? Do we marvel at the statue of an Egyptian Amelia Bloomer who encouraged immodest dress in impressionable young Egyptian women?” Rev. Davidson looks mournfully at us, as if expecting us at any moment to blurt out the names of such bold women.

I cross and re-cross my ankles, wishing my chair were closer to the fire.

"Women have power, of course," he says. "Isn't that right, Eliza?" 
Mrs. Davidson nods vigorously. "The moral authority a woman holds in her home is considerable."

"Yes!" he cries. "Because women have had power in every society, the kind of power they wanted and could handle. Here in America, men are badly besmirched by active participation in elections, and the women who attempt to purify the current election methods are apt to get mired in it themselves. Ask the poor women of the Wyoming territory. They didn't ask for this doubtful privilege. In fact, most of them don't vote because they don't want any part of the sordidness. They are happy to leave voting - that necessary, but nasty, business - to their husbands and brothers, their fathers and sons. The women of Kentucky are wise and know what they can handle. They understand that the kinds of people they would meet on the streets would only lure them into a frightening and dangerous world. Follow the path laid out by Egyptian women," he urges, "and be content with all you have been given in this life, for even women such as yourselves can be redeemed from the Pit."

He rests his hands on the table, bows his head. After a pointed glance from Matron, we clap.

I imagine the look on Matron's face if I were to point out the very obvious reason we don't study the writings and art of those Egyptian women - what husband or father or brother would record the words of such a quarrelsome woman?

"Reverend Davidson, thank you as always for enlightening us," Matron says. It is nearing Christmas time, when annual subscribers are asked to renew their pledge to support the Home. The reverend has been a faithful subscriber to the Home since it opened two years ago, so he could lecture on the joys of drowning kittens and we would be forced to listen attentively. 
"We certainly won't look at a simple bandage the same way again, will we, girls?" Matron asks, and we dutifully shake our heads and smile, a pack of dumb cows.

Since Catherine's death, Matron has lost weight, her former roundness replaced with a sharp angularity. Her dresses hang loose on her, even her hair seems limp. But it's her eyes that are the most noticeable. They are too big for her face, loose-looking, as if one good squeeze would send them flying out of her face. 


\section{Never seem to notice a scar, deformity, or defect of anyone present}

Last night Theresa cut her hair. The ends are jagged and barely skim her jaw. I have never seen a woman's hair so short; it's mesmerizing in its ugliness. Theresa's hair, and Catherine's when she was alive, changes color depending on the light. At times their hair reminded me of the honey Matron adds to biscuits when it is someone's birthday. Now that it's winter and we are indoors most days, her hair is darker, like maple syrup.

Catherine used to take great pains with her hair but there has always been a carelessness to Theresa's beauty, as if she couldn't be bothered.

Maggie and Matron spot Theresa's hair at the same time.

“Oh my God!" Maggie sets the pitcher of milk down on the table with an audible thunk.

Matron is forced to decide which sin is more grievous: the cutting of hair or taking the Lord's name in vain. "Maggie, please."

Theresa calmly pours milk into her tea and butters her toast.

“Theresa, please.” Matron's voice is pleading rather than scolding. "What did you do? What will the Board members say?"

“Oh, they’ll hate it,” Maggie says. "Especially Mrs. Davidson. It's terrible luck to cut your hair during pregnancy. Her baby will be born with all kinds of defects now. She'll catch a chill too, with her neck exposed like that."

Matron spends the morning curling and coaxing Theresa's hair into some semblance of a feminine style but the combs and pins only draw attention to her long pale neck. Matron finally ties a flowered scarf around Theresa's head and sends her into the sitting room. During sewing time, I sneak looks at Theresa. With the scarf, she looks like a gypsy. Surely this would anger the Board more than the haircut. 
I did not used to spend the hours between seven and nine sewing curtains, but I find it's calming to sit and work mindlessly on things that don't belong to me. There is a comforting drudgery to life in the Home. When I'm sweeping the floors and helping Matron with the laundry and sewing curtains in the evening, I am able to forget, for a time at least, just where it is I am doing these very familiar chores.

It's been threatening rain all afternoon, the sky a bruised plum, but the rain doesn't wrench free of the clouds until after supper. The drops make a satisfying noise on the roof, providing a natural a rhythm as I mend the curtains in my lap.

Maggie and I work on real lace curtains, which bring in an extra 25 cents. Theresa's stitches, neat and tidy, are better suited to lace but since her sister's death, I can't count on her to finish a set in time. Some evenings she simply stares at the curtains in her lap as if the whole idea of sewing is new to her, so now she mends Nottingham lace. Kate also works on Nottingham, not because she is a poor sewer but because she is afraid to work on real lace, in case she ruins it. When she was alive, Catherine was in charge of dividing up the sewing work, but it's my job now. I created a new system for the work closet recently, organizing the packages by date of arrival, rather than last name of the client. It's more efficient this way, although I felt a twinge of guilt when I un-did Catherine's method.

The curtains I'm mending this week are patterned with dragonflies and flowers. Aunt Janna used to say you could tell a lot about a woman from a glance at her curtains. After six months in the Home, and after mending countless curtains, I agree with her. Some curtains are frayed but clean and it's easy to imagine them hanging in bright and cheerful rooms. I've also mended odorous curtains, greasy to the touch. It reminds me of that saying about marriage: if 
your husband smokes, be thankful he doesn't chew tobacco. If he smokes and chews, be thankful he doesn't drink. If he does all three, be thankful he won't be around long.

I hand Cora a pair of scratchy red curtains to mend. New girls always get the worst of the bunch; this particular set smells strongly of tobacco and is covered in brown stains. She'll have to give them a good scrubbing with egg yolk to remove all those spots. "Be sure to use a thread that closely matches as you mend." I point at the basket of sewing supplies over by the fireplace. I hope she doesn't balk at chores the way Louise did.

“Today's lecture was ghoulish,” Maggie says. "I don't want to say it's bad luck in case that brings bad luck but...”

I look over at Kate and shake my head.

"You can’t be too careful, you know," Maggie says to Cora. "I once knew a woman whose husband kissed her, alcohol on his breath, and seven months later, that baby was born with six fingers on his left hand. This same man swore in front of his wife and guess what happened to that baby?" She doesn't wait for Cora to answer. "Deaf," she says triumphantly. "One good ear, and one ear completely missing." She runs a hand down her face and Cora stares. “The skin was perfectly smooth where the ear should have been. He couldn't hear a thing if you talked on that side. And here they let Reverend Davidson lecture on the most morbid topics to women in our condition."

Maggie loves to share stories about bad luck. Her parents and her husband all died the same year. "Died in his sleep," she said about her husband. "I never imagined such a thing would happen to a man who was only twenty-three. The worst part is, I don't think it was all that peaceful a death either. The look on his poor face.” After his death, she discovered he was in debt and she was pregnant. 
Maggie has a thick puckered scar in the middle of her right cheek. When she first arrived at the Home, I had to make a real effort to not gawk at it but now I hardly notice. How she got the scar is a mystery since she tells a different story each time. From a dog, she told me. From an uncle, she told Kate. When it's just us in the Home, she doesn't hide the scar but when someone from the Board visits, she grows terribly self-conscious. Maggie has very thin light-colored hair and no matter how she arranges her hair, the scar always shines through. When there are visitors, she hides in the kitchen or her room, claiming she's ill. She's like a cat that lived in our barn when I was younger, friendly as could be when we were alone, but who fled at the sound of an unfamiliar voice.

Maggie is also convinced that the tree across the street from us, the one covered in misshapen lumps and bumps, is haunted. She claims to have seen women gathering around it at night. Witches, she whispered so Matron wouldn't hear. Matron doesn't like that kind of talk.

From my bedroom, I have a clear view of the tree and on nights I can't sleep, I stand at the window and study the street below. I've never lived in a city as big as Louisville, and I'm always amazed at all the activity on the street. Once I saw a man relieve himself on the tree. Another time I saw a man walk around it, rubbing his hands up and over the bumps, as if measuring it. But nothing with women or witches casting spells; men are the only ones walking around the neighborhood at night.

To be fair, I don't fault Maggie for seeing bad luck everywhere.

"The only bad luck that will come from the Egyptian lecture is if Rev. Davidson forgets to return the bandage to the hall closet," I say.

"Are there lectures every day?" Cora stabs tentatively at the curtains with a needle and no thread. 
"Don't forget the thread," I remind her, and she crosses the room and returns with black thread.

"You'll want red."

"I don't actually know how to sew."

I laugh out loud. "You can’t be serious."

"No one taught me," she says somewhat defensively.

"Every woman knows how to sew," Maggie says.

"Not me."

"I've never heard of such a thing," Maggie says. "Surely you know how to crochet then." “Knit?” I ask

“Embroider?” Maggie asks. "Quilt?"

Cora shakes her head.

"Nothing in this life will surprise me now," Maggie says. "I have seen it all. A woman who doesn't know how to do something in her very nature."

I think of the ledgers in Matron's office, of all the money the Home is losing. "Sewing curtains is the main way we bring in money and we're expected to sew every night in the hours before bedtime."

"You're very lucky to be here," Maggie says to Cora. "There aren't many homes like this. Other cities just leave their girls to die on the streets."

"Dr. Munro said that Matron is a wonderful person and that I would really enjoy my stay here. How is the food?"

Maggie frowns. "This isn't a hotel, Cora. The last girl who complained about chores is no longer here. Louise.” She shakes her head. “A spoiled brat and I'm not afraid to say it, turning up 
her nose at this and that. You must do your fair share. I would offer to teach you, but Ruth and I are working on lace curtains, which bring in 50 cents each." She looks pointedly at Kate.

Kate puts away her curtains with a small sigh. "I'll teach you." She shows Cora how to thread the needle and gives her a piece of muslin to practice stitches. "The smaller the better." "If you want to know about the Egyptians, Cora," Maggie says, "I mean, really learn about them, ask Ruth. She went to college."

Cora laughs. "College! Is that true, Ruth?"

For some reason I think of the time Sadie fainted after a chemistry lesson, how she lay on the ground twitching, her fists clenching and unclenching as she gasped for air. Were these the hysterical fits we'd been warned would strike without warning, the natural result of too much mental stimulation? Miss Voght knelt down and loosened Sadie's corset and immediately she relaxed.

"I went to Oberlin. Lucy Stone graduated from there."

"I'd never heard of Lucy Stone before today," Kate whispers.

I try to hide the surprise on my face. "She was an abolitionist before the war. A famous suffragist too."

"I heard Dr. Munro say Lucy Stone has a very displeasing face," Cora says. "What happened to your face?" she asks Maggie.

"A rusty nail," Maggie says in a voice that discourages further questions. "I don’t know why the suffragists are so angry all the time. All that shouting about unfair treatment and demanding the right to vote will age them. I personally don't feel the need to go around begging for things I don't need. What does someone like me know about voting? What right do I have to thrust my nose into matters that have nothing to do with me? I saw Lucy Stone's picture in the 
paper once," Maggie says. She jabs at the curtains before her, as if it's Lucy Stone's face there in her lap. "She looks terribly old. Hideous, really."

"She is old," I say. "She's nearly sixty by now."

"Of course she looks older because of all that anger she carries," Maggie says. "Frowning and shouting are not good for the complexion."

"I would be too frightened to vote," Kate says. "What if I did it wrong?"

"You wouldn't be wrong if you voted with your conscience," I say.

"What if I cancelled out my father or husband's vote?"

"If you had a good reason to do so, maybe that would make them re-consider their own position."

"Of course she's angry," Theresa says suddenly. "And old-looking." This is the first time we've heard her voice in over a month. The words sound as if they are scraping her throat. Maybe all she needed to do to find her voice was cut off her hair. She keeps her head bent over the curtains in her lap as her left hand moves the needle in and out of the fabric. "She's tired of being told she doesn't know what she's talking about."

I wonder if she is talking about herself or Lucy Stone.

"Look!" Cora triumphantly holds up the fabric in her lap to reveal a trail of uneven red stitches. "Dr. Munro always said I was a quick learner." 


\section{The Courier Journal ${ }^{19}$}

\section{Joy to the World! Woman is Free!}

Among the many modern discoveries looking to the happiness and amelioration of the human race, none is entitled to higher consideration than the renowned remedy Dr. J. Bradfield's Female Irregulator, Woman's Best Friend. By it woman is emancipated from numberless ills peculiar to her sex. Before its magic power all irregularities of the womb vanish. It cures suppression on the menses. It removes uterine obstructions. It cures constipation and strengthens the system. It lances the nerves and purifies the blood. It never fails, as thousands of women will testify. This valuable medicine is prepared and sold by L.H. Bradfield, druggist. Price $\$ 1.50$ per bottle. All respectable drug men keep it.

${ }^{19}$ August 1876 


\section{A lady should have the escort of a gentleman in the evening}

The Home is the oldest on the street, built in 1870, and it's set further back than the other houses.

On the day I arrived, I noticed the gray stone and red door, the flat roof, the tall pointed windows flanking the front door. That day, I did not notice the fountain in the backyard, filled not with water but with a creeping plant. I did not notice the witches' tree across the street.

I don't know how far we are from the river, but I can smell it somedays. A deep, dark smell that manages to sneak inside the Home and get into our clothes. Maggie says that's not the river, but the stench of stockyards, where the Irish live. How strange to live by water and yet never see it.

I was here for a whole month before I discovered the gargoyle perched above the porch, watching the street with narrowed eyes and crossed arms. Maggie says we're lucky he's there to keep bad spirits at bay because who knows what kind of bad luck would befall us otherwise.

In our rooms we are permitted a rug, a washstand, a mirror, and a rocking chair. We are not permitted books, writing materials, pets, plants, letter openers, or knitting needles. Mrs. Davidson recently complained to Matron about the mirrors but Matron assured her that should she observe a sudden onset of vanity or immodesty, she would personally remove all mirrors from the Home.

I have a new nighttime ritual that Mrs. Davidson would surely see as confirmation of this immodesty. When the house is finally quiet, I shed my nightdress and stand before the mirror to study my naked body.

In seven months my breasts have nearly doubled in size and spill out of my palms. My stomach, which has also doubled in size, does not ache in the same way, but I do feel the need to cup my hands underneath it, as if it's a too ripe apple about to fall from a tree. 
It isn't vanity that draws me to the mirror each night. The woman who stares back at me every night is a poor imitation of the woman I once was. The mirror woman is a fallen woman, a sinful woman, a Magdalen. My first week at the Home, I woke to find my naturally straight hair had a natural wave to it. Even my hair is unfamiliar.

If I were to leave the Home, walk out the door right now, maybe all these things would fall away one by one and by the time I reached the end of the street, my hair would be straight and my stomach flat and if this happened, I would give up mirrors for the rest of my life.

Was I vain, before? Maybe it is vanity to say no too quickly, to disavow that there was ever a time I took excessive pleasure in my appearance. It's true that in the past I spent very little time contemplating my looks, and now I spend quite a bit. But I am certain that my only vanity back then was the mistaken belief that my body was mine alone to control.

Last spring, my dresses grew uncomfortably tight across my chest. I knew then but I couldn't make myself tell Miss Voght until the summer. When I finally told her, I was crying so hard she didn't understand. Once she finally did, she made me pennyroyal tea which smelled of mint but tasted like burnt bark. I drank every last drop. It didn't cause any bleeding, only made my legs cramp painfully that night.

There are other ways to remove an obstruction, Miss Voght said, which made me start crying again.

On my bed is the quilt Miss Voght gave me the day I left Oberlin. If you look closely, you can see the blocks are different sizes and the lines are uneven. She never was very good at the domestic part of our lessons.

I hope it keeps you warm, Miss Voght said when she gave it to me. It was the last thing I packed at Oberlin and the first thing I unpacked in my room at the Home. I have slept under this 
quilt every night for five months and I will tell Miss Voght, if I ever see her again, that it has kept me warm and is the nicest gift I've ever received and that I will leave it behind when I leave the Home. A different girl will sleep under its simple block pattern, and I hope it keeps her warm, when her tears fall and mix with mine.

I've had such peculiar dreams since arriving at the Home. Last night I dreamed I was a man taking a walk through the park. A cane announced my arrival. It was nighttime but I was not scared of the shadows or the other men because they greeted me warmly, tipping their hats at me. They wanted to know where I was going, and what I thought about the news of the world. In the dream I talked and talked until my mouth ached. It was nice to have a mouth hurt from talking.

Something is inside me, something I did not ask for, and it grows a little every day without any effort from me. In the mirror, my stomach hardens and ripples as the obstruction moves. Just because you don't want something doesn't mean you aren't occasionally amazed by it. 


\section{Never will a gentleman allude to conquests which he may have made with ladies}

Cora is struggling with her knitting lessons. Tonight she holds the needles as if they are small animals trying to bite her. Kate is patient as she explains how to cast on, and she is patient when Cora asks for help every few minutes.

“Oh, I'll never learn!" Cora is on the verge of tears.

"Of course you will," Kate says. "You have to practice, that's all."

I am impatient simply watching this knitting lesson, but there is a seemingly unending reservoir of patience in Kate.

Kate is nearing confinement and her stomach is so large she needs help getting out of her chair. She's taken to sleeping upright in the rocking chair in her room because she said she can feel her supper sitting in her stomach. Like a stone shooting up flames into my throat, she said. She's embarrassed at how often she needs to use the bathroom.

"Theresa, you could show Cora how to knit," Maggie says. "She knits the most beautiful things. Such intricate patterns. You should see her scarves."

Theresa does not look up at the sound of her name and does not offer to show Cora her knitting prowess.

"If you practice every night, you might be skilled enough to make something for your baby before you reach confinement," Kate says.

"My baby?" Cora asks. "I don’t have a baby, you silly girl."

Maggie once told us about a woman she knew whose stomach grew hard and round but instead of a baby, it was cancer. When she said she wasn't pregnant, no one believed her. Only in death was she finally credible. There's something almost obscene about the health radiating off 
Cora, everything about her is plump: her cheeks, her arms, even her lips are full and pink. Her stomach is nearly as large as mine. I feel something tighten in my own stomach.

"I'm not here to have a baby like you girls," Cora says. "My stomach got a little fat but that happens, if a girl eats too much pie. Dr. Munro brought me here to stay for a few months because he and Mrs. Munro are going to visit her sister in New York for a few months and she Mrs. Munro's sister, that is - doesn't have room in her house for me. Besides New York is so cold! Better to stay here in Kentucky and rest while they are away. They'll come back for me, when the visit is over. They're so good to me."

It's been raining for two days now. An insistent rain. Are the people who live by the river fearful of the water swelling its banks, the inevitable breach onto land? I have not seen any men walking at night in this weather.

Maggie and Kate are still, their sewing forgotten. Even Theresa has paused in her sewing.

"Your stomach isn't fat from too much pie," I finally say. "We're all here for the same reason.” I am suddenly angry with her. Furious. It's all I can do to stop from kicking her fat pink ankles.

"Not me!" Cora shakes a knitting needle in my direction. "What wickedness to suggest such a thing. I'm only fourteen years old."

As a child, whenever I did something that displeased Aunt Janna, she would say, That's your mother in you. According to Aunt Janna, her sister was a selfish woman obsessed with her own beauty and intelligence. Aunt Janna was a thick woman who saw little need for ornamentation, for reading, for anything that might be classified as the devil's work. 
Aunt Janna came to live with us when my mother was pregnant. My father was a farmer and an artist. He liked to paint quaint country scenes: thatched cottages with colorful gardens, burbling brooks running behind a pretty farmhouse. I don't know where the idea for these paintings came from. Outside my window I saw only fields, yellowed in the fall, green in the spring.

Rather than sell his work, my father preferred to give it away, something which, according to Aunt Janna, drove my mother crazy. This much is true because I found my mother's diary in the attic. On the first page she wrote, I look outside the window of our house, at the changing light and the changing trees, and I compare this to the rivers and cottages he paints and gives away, and it makes me want to scream. She pressed so hard with her pen on the word scream the ink is darker there.

Later she tried her hand at painting with paper and brush stolen from her husband. All the colors he was ignoring in his own work! She would use them all. Such a shock I received, as my brush slid across the paper that first time.

I paint like a God, she wrote.

I found a stack of her paintings in the attic, lovingly wrapped in an old blanket. The paintings were self-portraits mostly. In some she is nude and in others she is smiling. In my favorite, her hair is a swirl of pink and green, her eyes two flat sapphires. Her body is a shadowy absence, a series of brushstrokes, there but not there.

What were you on about, Mother?

She finally showed her work to her husband. He doesn't understand what I am trying to express. This is partly my fault, as the artist. But I refuse to take all the blame. 
I wish I had one of these paintings now, to hang above my bed in the Home. The Board doesn't think that art in the home would serve girls of our class. I wonder if Mrs. Davidson would find the painting or the mirror a more corrupting influence.

Before I was born, my mother moved to New York for a year to focus on her art. The months she was away, she wrote her husband a letter a week. Why he saved these letters I don't know but I found them in the trunk as well, bound with a piece of twine. At times she adopted a chatty, conversational tone, asking advice about how to keep her brushes clean, how to remove paint from the skin. Sometimes she teased him for being so conventional. Tell me, my dear-are you still in love with the past? You never could resist those Italian artists so enamored with their own image.

Other times, she was critical, cruel even. When she learned he sold a painting, she wrote, I feel no pride in reading this news, for I know the painting you speak of and I pity the person drawn to purchase such blandness. In that same letter, she asked him to send money.

Eventually she ran out of money. When my father refused to send more, she came back, walking inside their home as if she'd never left.

Just pranced her fancy self right back in, Aunt Janna said. No apology, no plea for forgiveness.

I was born nine months later. My mother complained about pain in her legs after delivery, and the doctor applied blistering poultices to her legs. He told her to rest in bed for a month. When she was given permission to get up, she pinned a flower in her hair and walked into the dining room where my father was eating supper and I was napping in my cradle. Oh, what a pity, she said before collapsing. She was twenty-six, six years older than my current age. 
A week after her death, my father went into the woods with his shotgun to hunt for turkeys and did not return.

She killed him, Aunt Janna said. As surely as if she fired that shotgun herself. Her face was unexpectedly tender when she spoke of my father.

As a young girl, when I would see girls with their mothers or their fathers, I would think that having parents seemed nice. But it also seemed incompatible with my life, like waking up one day to discover I lived in a castle and spoke fluent Portuguese. I've imagined telling my mother about this baby, and she always looks up from a painting of herself to say, $\mathrm{Oh}$, what a pity before collapsing. 


\section{Never read letters which you find addressed to others}

Most days I spend the hours between breakfast and lunch in Matron's office. Her eyesight is failing, and she desperately needs an assistant, but Mrs. Davidson says there's no money for one. Her desk is a mess and she's constantly losing things. We spend the first part of the morning searching for her green-handled letter opener and her eyeglasses and her teacup. I can't find the former, but I locate the cup beneath a stack of papers by the window, and I point out that her eyeglasses are tucked into the sleeve of her dress.

Sometimes I imagine this is my office, and instead of porcelain angels and lace doilies lining the bookshelves, there are hundreds of books and on Saturdays I curl up on the sofa with one and don't emerge until suppertime. Instead, I sit at the desk Matron has set up in the corner by the window and I look through the newspaper for mentions of the Home. Matron has saved every article, even the early ones before the Home officially opened and neighbors were concerned about sinful women moving in next door to good Christians. Those were trying times, Matron once said.

It's cold and drafty by the windows but I have a clear view of the street, and I would read through the newspaper and look out the window all day if I could. Based on the way people walk with heads bent low, hands thrust into mufflers or pockets, it must be cold out there. Today is coal delivery day, and I watch for the wagon. Even though the coal is stored in the basement, delivery day means extra sweeping. That dust manages to travel upstairs and dance about the floors.

We are allowed outside once a week to attend church services. There has been talk of building a chapel in the Home so we don't have to leave the house at all. I hope the chapel is built after I leave because I will take the staring and the whispering at church if it means we are 
allowed to breathe the outside air. The closer I get to confinement, the less I enjoy our Sunday outings. It's like being given a single bite of bread when you are starving to death; it only makes your hunger more acute.

I find two mentions of the Home in today's paper. The first is an annual report detailing expenses. Seeing the budget in print, it is clear that even if we sewed curtains day and night, the Home would still be in serious financial trouble. Without more subscribers, it's doubtful the Home can keep going another year. The last sentence of the report reads, In October, one woman died in childbirth. Catherine left a clear testimony that the Home had blessed her and changed her for the better.

The last thing Catherine said was, Don't let him do that to me! I was haunted by the unnamed him. Was she talking about the doctor who couldn't stop the bleeding? The son who was the reason for the bleeding? Or the man responsible for the labor that lasted an entire day and a night? I cut out this article, along with one about the package reception scheduled for Christmas Eve, and paste them into the book. I think about the girl who will help Matron find articles after I leave. Will she run her hands along the cracked black leather covering? Will she drag out this task, painstakingly pasting the articles into the yellowed pages with a precision and patience she did not know she possessed?

Matron also keeps letters from people asking if the Home has room for someone they know. These are not in an official book but hidden inside one of the many Bibles in her study. Maybe this is not a hiding place, although I think it is because Matron has never asked me to file and catalog these letters and she is very big on organization. I always tell myself I won't snoop and read letters that have nothing to do with me but I always lose my resolve after a few weeks. 
"Coal's here," I announce when the wagon arrives. Once Matron is downstairs, I find the Bible, third from the left on the second shelf. I spot the new letter immediately, cream-colored stationery with a pleasing thickness, the penmanship practiced and unhurried:

\section{Dear Madam,}

I would like to express my admiration for the work you have been doing with the fallen women of Louisville. The good and restraining influences you model to girls of this class, combined with a solid Christian education, will surely yield women our country will be proud to claim.

A young woman under my care is in need of shelter and concealment. Unfortunately, I have been unable to secure lodging for her at our home for fallen women here in Nashville. I can assure you that Cora is a good Christian girl and will gladly embrace all opportunities for self-improvement. That she should have fallen into sin is sadly a common occurrence with young women these days, as I'm sure you have had reason to discover. Unless I hear from you otherwise, I will bring the girl next month and leave her in your capable hands. As a small token of my appreciation for your charitable Home, I will send a small sum of money which might offset the burden of one more sinful woman and aid in future endeavors of your esteemed Home.

Yours sincerely,

Dr. William Munro

I think of Cora shaking her knitting needles at me: I'm not here to have a baby! When Matron isn't looking, I slip the letter into my pocket. I did not used to be the kind of woman who took letters and engagement books. It's amazing how quickly you can become someone you don't recognize.

Matron is worried the dreary cold of January and February will turn even the most generous of subscribers into misers. She wants to send a letter in advance of Christmas, when 
generosity and good will are still abundant. I am very good at writing these letters. Since I started helping with letters, we have had three additional subscribers. I read aloud a paragraph to Matron:

I have had countless pitiable Magdalens enter the Home with heart-rending sobs and streaming eyes to ask, "Will not those who profess to be Christians help us to leave the dens of sin, shame and misery into which we have been driven by men who by false promises accomplished our ruin?" Any money sent to us would be thankfully received and acknowledged by these respectable friends.

Matron listens with closed eyes. "We can send that to male subscribers," she says. "For the women's groups, add more about repentance." As she talks, her glasses slip down her nose. They do little to counteract the cloudiness that skims across her eyes. I wonder if she will ever gain back the weight she lost after Catherine's death.

"Tell me, how do you think Cora is doing? She has a very cheerful disposition although she needs quite a bit of instruction with her chores."

A sinful woman, Dr. Munro wrote about the 14-year-old girl in his care.

"Most girls her age are cheerful," I say.

"I suppose she was quite spoiled before."

“I'm worried Cora doesn't understand why she's here."

Matron takes off her glasses, rubs her face. "She understands."

"She claims she is fat from eating too much pie."

“Girls aren't sent here for eating too much pie. She simply doesn't want to own up to her part in this."

"When I was her age, I too might have thought I was simply fat. No one explained these things to me." 
I think of my old barn cat, how one day she ran into the woods behind our house and when she returned a few weeks later, her belly was swollen and she crawled under our porch to deliver six kittens. For a long time after that, I thought that if I ventured too far into the woods, I too would end up with a bellyful of babies.

"According to Mrs. Munro, Cora was acutely aware of the part she played in her downfall."

"Cora is barely aware of how to hold knitting needles."

"Ruth.” Matron's voice is a warning I don't heed.

"Surely Cora is not the first girl Dr. Munro has sent to a Home like ours."

“That's enough, Ruth."

"Why is it that we are the ones sent away, and nothing happens to them? They are allowed to stay and go about their lives. Tell me, where is the fairness or justice in that?"

My heart is pounding as if I stepped too close to a cliff and find myself free falling. Rage sloshes inside me, liquid hot. It threatens to leak out as tears.

There is a long silence. When Matron finally speaks, her expression is unreadable. "Are you truly repentant, Ruth?"

I swallow hard, clench and unclench my hands behind me.

"No one is too far gone for salvation. This is a lesson I learned myself many years ago. But you must ask for forgiveness," she says, "and you must acknowledge your sins."

I wonder, not for the first time, why Matron spends her days worrying about the finances of a Home for pitiable Magdalens. It's hard to imagine her as a friendless woman but of course she has not always been Matron. Maybe she is surprised when she looks in the mirror at night 
and sees a woman whose hair is more gray than black, whose skin is loose, especially under her chin and around her stomach. Whose eyes are those? she thinks.

"The world will not bend to your will, Ruth. Your stubborn attitude will not serve you." "I don't know how to be someone I am not."

From the window I watch two men walk down the street. They walk in unison in a way that makes my throat ache. What I would give to be outside, to exercise, to walk. The smell of freedom would bring me to my knees.

Matron follows my gaze. "We had a problem with the first group," she says, in answer to my silent question. "Girls leaving without permission, trying to go home or, worse, back to their sinful ways."

"I would not return to my sinful ways if I were allowed outside. I was not a sinful woman before," I say to the window.

"You are here for the same reason as the other girls. Pride will hinder your effort at true repentance."

I am smart enough to hear the dismissal in her words. Even Matron has a limit when it comes to girls of our class.

When I am alone, I pull out Minnie's book and transcribe all the words used to describe us in the paper today: we are respectable friends, victims of misfortune, pitiable Magdalens. How strange to be all these things at once. After a moment, I add one more of my own.

Liars. 


\section{Ladies should not allow courtship to be conducted at unseasonable hours}

Kate told me a riddle when she first arrived at the Home: Her mother had eight children but was only pregnant four times. I guessed four sets of twins, but the correct answer was two sets of twins, one set of triplets, and Kate. Kate keeps a drawing of her family in the top drawer of her dresser. In the picture, Kate and her mother have the same curly dark hair and her brothers and father all share dark eyes and darker hair.

Since Catherine's death, Kate often comes to my room on the nights she can't sleep. Her room overlooks the back garden, and she said the only shape she can make out in the dark is the diseased ash tree. Maggie would claim it's bad luck to stare at a diseased tree in our current condition. "It's impossible to hear someone constantly mention bad luck and not believe the occasional story," Kate said.

Kate climbs into bed with me. We lie back to back, our stomachs jutting out on either side, like the wings of a strange animal. I used to sleep on my back but now my stomach looms above me and I can't breathe, as if my own body wants to crush me. I adjust the quilt so it covers us both.

"Do you ever think about Catherine's baby?" she asks.

I sometimes picture his stillness, the cord wrapped around his neck like a noose. I can still see Matron struggling to cut the cord, how she had to bear down with the scissors. "No."

“He wasn’t baptized,” Kate says. "I pray for him every day but I don't know where he went." I can tell she is crying from the way her shoulders shake.

The nearer Kate gets to confinement, the more she worries about this baby, specifically his soul. During labor Catherine screamed until she was hoarse, her eyes wild. Even at the end Theresa could not calm her sister. Am I being ripped apart? Or in half? she kept asking. 
Bear down one more time, Beatrice, the doctor said.

Her name's not Beatrice, Theresa said, but her words were swallowed up by Catherine's screams and the rush of blood and I sometimes worry, the way Kate worries about her son, that Catherine left this world as Beatrice, and what happens to a person if they leave as someone else?

The baby shifts inside me, and I rest my hands on my stomach. We find ourselves in purgatory, the constant threat of death hanging over us, the constant reminder of life moving within us.

"Do you ever worry about dying, Ruth?"

"Yes."

"I wish I were more like you. You hide your fear well."

"Matron says I am prideful and my aunt used to say I was too stubborn for my own good," I say. "Best not to copy me."

I imagine I can hear Kate smiling in the dark. "Did you have a friendship album when you were a young girl?"

"Of course."

"I was very good at drawing pictures. Dogs, boats, castles. I bet you wrote limericks."

"Poems mostly."

“About marriage?"

"About death," I say. For some reason this strikes us both as funny, and the bed shakes with our silent laughter.

“Tell me one," Kate says when she catches her breath.

I'm only half joking when I say, "Don't tell Maggie."

When I am dead, my dearest, 
Sing no sad songs for me;

Plant thou no roses at my head,

Nor shady cypress tree. ${ }^{20}$

"How morbid!" she cries.

“Aren't all young girls?"

"Oh not me," Kate says.

I believe her. As a young girl, Kate was exactly like she is now: patient, kind, forgiving.

"What would you write in my friendship album?" I ask.

"I would draw you a picture."

"Not a picture of Reverend Davidson lecturing about suffrage, I hope. How difficult to capture all the sweat."

We collapse into giggles again.

"Silly girl, I would draw a picture of the house you'll live in when you leave here. The house for you and your baby."

Kate believes that as soon as the baby is born, I will change my mind, that my love for this baby will pierce me like a thorn. She says there are lots of men who will marry me, that I can assure people I was once a sinful woman but am now a penitent Christian woman. She sounds exactly like Matron when she says these things.

"Will you let me visit you?" she asks. "You and the baby?"

I nod even though she can't see me in the dark. I don't trust myself to say yes or no.

${ }^{20}$ Christina Rossetti, "When I am dead, my dearest" 
"It will be hard to return to the farm after this," Kate says with a sigh. "After living in a house with a parlor and a dining room table that seats twelve and a mirror in every room. William might think I'm too fancy for him."

Kate said that on the drive to the Home, her fiancé William cried and cried, while she sat beside him, dry-eyed. She said if I had seen his face and looked into his eyes, I would know how sorry he was for her condition and this is how she knows that he is back home saving money so he can marry her and provide a home for their family. She said that she hoped that someday her family, and especially William, would forgive her.

When I asked why she was the one who needed forgiveness, she said it was her fault they sinned.

"I have a request," Kate whispers now. "If I die."

"You won't die."

"Catherine did."

I think of the daily retching I heard from her room, even after the point of quickening. "Catherine was sick every day of her pregnancy, and her baby came too early."

"But if I die, will you make sure the baby is baptized?"

"You aren't going to die."

She rolls over so we are facing each other. Her hands find mine. "Promise me, Ruth." I squeeze her hands. "I promise."

She relaxes onto her back. "What would you write in my friendship album?" "A poem."

"A happy one?" 
I think of the poem Minnie recited on her visit, how she left off the part where poor Kate is put in her place by her cousin, the fallen woman.

Yet I've a gift you have not got,

And seem not like to get:

For all your clothes and wedding-ring. I've little doubt you fret.

My fair-haired son, my shame, my pride, Cling closer, closer yet:

Your father would give lands for one

To wear his coronet.

I do not want a son, fair-haired or otherwise. I do not want him to be my shame or my pride.

Wanted or not, a baby should not be asked to carry such a burden.

The last time I did laundry at Oberlin, I laid out my dresses to dry with the arms thrust upwards. From a distance, they resembled Christ on the cross and when I returned for the windwarmed clothes, I was as tender as Mary, gathering her son one last time into her arms.

I am 223 days removed from the incident at Oberlin, and I have not changed my mind about this baby. There is a world where the baby and I live in a nice home and Kate and her family visit us, but that is the make-believe world of friendship albums. 


\section{A true lady will go quietly and unobtrusively about her business when on the street}

Sunday morning we walk the short distance to the Second Presbyterian Church. We waddle behind Matron, two by two. Like fattened ducks. The cold air burns, and I gulp greedily at all the smells: trees, smoke, leaves, horses. It is the smell of an active and busy world, not the smell of women and endless piles of curtains and laundry. If Matron would allow it, I would sleep outside. I imagine her face if I were to ask such a thing, and I laugh aloud as I walk. Even with my stomach jutting before me, there is a lightness to my body.

We pass by the tree Maggie claims is haunted, and the statue of the man on horseback at the entrance to the park. He gazes past us at a spot in the distance. My first week in the Home I dreamed that I walked over and laid my hand on the statue and the horse became alive under my hands and when I looked up, the man was gone and I knew, in the way of dreams, that this was my horse now and he would take me wherever I wanted. When I woke in my bed at the Home, I cried like I was back in Oberlin telling Miss Voght about the baby.

Matron likes us to read from our Bibles as we wait for the service to begin. I suspect this rule is as much for us as it is for the other churchgoers, so they will see us as pious and humbled. The girl who had the Bible before me was fond of The Psalms because my book naturally opens to 25 . I have read these words enough times that they feel like a message specifically for me.

Be mindful of thy mercy, O Lord, and of they steadfast love, for they have been from of old.

Remember not the sins of my youth, or my transgressions;

according to thy steadfast love remember me, for thy goodness's sake, O Lord! 


\section{Good and upright is the Lord;}

therefore he instructs sinners in the way.

He leads the humble in what is right,

and teaches the humble his way.

Today's sermon is about the demon of worry. "We are not orphans as long as God is our Father," Rev. Davidson begins. It's cold enough in the church that even he is bundled up and not sweating. Sitting next to Kate and Maggie, the heat from their bodies, I am comfortably, drowsily warm.

Worry, Rev. Davidson reminds us, is the work of the devil and will not help us in this life, or in the one that follows. Surely it's not possible to go through this life without worry. But I listen, thankful to be spared a message about the evils of suffrage. I see Mrs. Davidson and Minnie in the front row. Minnie stifles a yawn and looks around the church but Mrs. Davidson listens intently. After one of his interminable lectures about suffrage, I saw the Reverend place his hand on the small of Mrs. Davidson's back. "You are a great comfort to me, Eliza," he said quietly. "I hope you know that." And the smile she gave him was so open and trusting, she was briefly as beautiful as her daughter.

This is my body, given up for you we sing, and then services are over. 


\section{A true lady will always be cool, collected, and self-possessed}

The sun darts in and out of the clouds on the walk home, and the air smells of snow. "We should all be careful today," Maggie says. "Abrupt changes in weather are bad luck for women in our condition."

Kate is walking slowly today, even though she's not one to normally dawdle and draw out our final moments of freedom. She doesn't answer when I ask if she feels alright and shakes her head no when I ask if I should get Matron. When we reach our street, she suddenly grabs my hand, squeezing so hard I gasp. Her normally small eyes are wide and frightened.

As we climb the three small steps to the Home, Kate stops. "Oh." She holds her hands beneath her stomach and looks down at the puddle forming beneath her skirts.

It takes us a long time to climb the stairs to her room. On every step she pauses and pants.

"Please no doctor," Kate begs once we're in her room. I help her strip off her wet garments and change into one of the nightgowns reserved for birth days. I braid her long hair to prevent tangles while Matron piles blankets and sheets atop the bed so it's easy to strip afterwards. "My mother never had a doctor present and she delivered healthy babies every time."

There is a tally in the kitchen of how many babies have been born in the Home. The specter of Catherine's son, baby thirteen, hangs over us now.

"You have until sewing time," Matron says. "After that I will call a doctor whether you wish it or not."

I kneel beside Kate and give her fingers a reassuring squeeze. I hope she doesn't notice how mine shake. 
A slushy rain begins falling around lunchtime. At one point Kate climbs out of bed to rock back and forth on her hands and knees. Her moaning and the sound of the sleet on the roof blend together into a terrifyingly beautiful sound.

Maggie relieves me in the afternoon, and I sit at the dining room table and eat bread with cheese and fruit even though I'm not hungry. Even from downstairs I can hear Kate's cries.

Most days I can forget what lies in wait for me, but on birth days I am reminded that my own body will crack open to release what's inside. It might take hours or days, but there will be no escaping the pain. I have experienced many painful things in my life, yet I have seen that childbirth is different.

After Catherine's death, Matron asked the Board for chloroform to help with prolonged labors. Mrs. Davidson refused. "How will these girls earn humility and self-improvement if you make even the curse of Eve manageable?"

I wonder what happened to Mrs. Davidson, to make her so hard, that when given the chance to alleviate pain in a fellow woman, she chooses pain.

With the approach of evening, the sleet becomes snow and falls silently. I am not one to normally pray but I say a prayer that Kate will deliver her baby without a doctor.

When I return to Kate's room, the room smells of iron. Matron is kneeling between Kate's legs. Catherine's doctor was so old that we had to help into the chair we had placed at the foot of the bed. He refused to look between her legs and instead blindly groped under the sheet while staring at a spot on her forehead. His fingernails were ragged and dirty. As I helped Theresa wash Catherine's body to prepare her for burial, I thought that I would not want that doctor's filthy nails scratching at me. 
"You're doing just fine," Matron says to Kate, and she lowers the sheet back over her legs. A white ring of dried sweat circles Kate's forehead like a halo. Kate stares at a spot past us on the wall; she is here and not here. I wonder if during labor, I too will find a way to be present in body only.

Kate suddenly sits up in bed and rests her weight on her elbows. The bearing down pains are much closer together and last longer. She claws at the sheet until she rips a small hole. When I try to wipe her forehead with a cool cloth, she violently shakes her head and moves out of reach. She takes a deep breath, as if about to plunge underwater, and this time when she bears down, there is a sound of something breaking loose, or breaking free. Blood too, the right amount, and the baby's head briefly appears.

"Two good pushes," I tell her, and amazingly the baby slides out after her second push. Matron snips the cord and wraps it in a piece of linen before securing it to the baby's belly. I wipe his eyes with a cheesecloth and hold him up for Kate to see. In my arms, he is warm and smells like the inside of a barn.

“Ten fingers, ten toes?" she asks wearily.

"Ten of everything."

I wash the boy as Matron delivers the placenta. During his bath, he opens his eyes and then quickly closes them, as if he unsure of this new place he finds himself.

"You would make a fine nurse, Ruth," Matron says as I swaddle him. Kate is fine and her baby is fine, and tears of relief fill my eyes.

Kate suddenly cries out again. She looks at me with terrified eyes, and I am afraid she will start convulsing like Catherine did. "There's another one," and then she half screams, half groans and grabs for the sheet again. 
The second baby does not come out with two pushes because the baby's left shoulder gets stuck. Matrons slowly maneuvers and turns the baby until finally the left shoulder is out too. This turning and twisting is not painless for Kate; at one point she faints. Likely it is not painless for the baby either because she emerges screaming. She screams as Matron cuts the cord, screams as I wipe her eyes, and screams during bath time, as if the water is scalding instead of cleaning her. Only when she is swaddled and lying beside her brother does she grow quiet. The two babies curl against each other and offer shuddering yawns. The girl is nearly bald, only a few blonde wisps, but the boy has dark hair that sticks straight up in the air.

"Twins," Kate says. "I should have known."

"Your mother had twins," Matron tells her with a smile. "This is not uncharted territory for you."

While Matron strips the soiled linens from the bed, I help Kate with her bath. The water flashes red then murky brown. Afterwards, I help her into a clean gown and pile blankets onto her legs to keep her warm. She falls into an exhausted sleep almost immediately.

Before bedtime, Maggie and Theresa visit. "Look at that hair," Maggie says about the boy. Theresa is silent, her expression unreadable, as she stands over the twins. Whatever she is thinking, she does not feel the need to share.

Even though I have scrubbed the floors and the soiled sheets are downstairs in the laundry room, Cora refuses to come inside Kate's room. "It smells funny," she whispers, wrinkling her nose. "Are you in pain?" She is standing in the hallway but her stomach is so large it is in the room with us.

“Oh yes," Kate says. 


\section{Do not be afraid of being an "old maid" for the term has lost its disgrace}

In the spring and summer at Oberlin, we girls were required to be in our rooms by eight, half past seven in fall and winter months. The boys did not have a curfew. We were permitted to visit the library between six and ten on Saturday mornings, while the boys did their outdoor chores. Interactions with male students were discouraged.

Never speak to a man through an open window.

Never walk to class with a male student.

Never under any circumstances visit a man in his room.

As evidenced by the number of engagements published in the Oberlin Review each spring, a number of students broke the rules.

Most of the girls at Oberlin wanted to find a husband before graduation. Contrary to what Aunt Janna said, I was not opposed to the idea of a husband. My first year I simply found it easier to avoid all the romantic entanglements that everyone else found so intoxicating. This seemed especially prescient on my part after my roommate Sally was expelled our first year for what the Oberlin Review called "moonlight wanderings" with two unnamed male students. I had the room to myself after that, which I didn't mind at all.

All Oberlin girls were on the literary track. We jokingly called ourselves The Ladies Department. Instead of Latin and Greek, we studied French, poetry, modern literature, and religion. Every semester we took a class called Household Economy with Miss Voght. No one knew how old she was. Thirty? Forty? She did not wear a wedding ring but rumors swirled around her: that her husband had left her for someone else, that her fiancé had died in the war, that her husband was royalty and lived abroad. Most of the girls thought her strange. They didn't 
understand her plain dresses and her simple hairstyle or how she could be content teaching us, instead of raising her own family.

"You are here for a useful education," Miss Voght said on our first day. "You are also here to be a restraining influence on the male students, to model superior manners for those young men who will go on to become ministers." Nine girls anxiously stared back at her. "That is a tall order. You can be sure the male students are not being lectured about the need to control your unbridled passions." We blanched in surprise; a few of us blushed.

"How many of you know how to sew?"

All hands rose.

“Cook? Garden?”

"What about physics? Chemistry?” Our hands swiftly returned to our laps.

"There's a way to study both the domestic and the sciences," she said. "But if anyone back home asks about your classes, be sure to focus on the former."

Our studies were interrupted on Mondays so we could wash and repair the men's clothing, on Tuesdays so we could attend the men's debate meetings, and on Wednesdays so we could clean the dining hall and other buildings on campus. My favorite room to clean was the Museum in the science hall. It wasn't technically a museum but it was well-stocked with botanical specimens and ten microscopes. For use by male students only! read the sign above the microscopes. I often wondered, as I cleaned and organized that room, what ideas they feared would fester within us girls if we were to look through the eyepiece of a microscope, what else we might ask to see for ourselves.

On cleaning days, I always requested the Museum. Most girls disliked the smell of the drying skins in the taxidermy room next door but I dragged out this chore so I could say aloud 
the names of the plants as I cleaned their glass cases. The poisonous ones sounded especially beautiful. Mandragora officinarum. Conium maculatum. Before coming to Oberlin, I had known to avoid these poisonous plants by their shape alone, and I was seeing now that there was a whole world hidden beneath the one I had known. It was like being handed the keys to a secret kingdom. What if I graduated before I looked at all the plants in the glass cases, before I read all the books in the library, before I crammed myself full of knowledge? While in school, we girls were indulged, we were allowed to simply be. But after graduation, we were expected to leave it all behind, so our real lives as wives and mothers could begin.

I worried I would be Lot's wife, unable to avoid the temptation to look back for one final glimpse. So many ways a woman can turn to salt. 


\section{The Courier Journal ${ }^{21}$}

\section{Frankfort Gossip: Woman as Office-Holder}

Before and since the election of State Librarian, the subject of woman as office-holder has been exhaustively discussed. Mrs. Cornelia Bush is the first and only lady who has held an elective office in the State, a special set having been passed in the Legislature two years ago, opening that office to the admittance of women. It is admitted by all that Mrs. Bush has fulfilled every duty of the office efficiently and to entire satisfaction. I have heard more than one gentleman testify to the agreeable changes that have transpired since she has taken charge of the Library rooms. The neatness and entire order prevailing where was wont to be confusion and dust - every book in its place, the added grace and cosiness which her taste and untiring care confers upon a room. Therefore the question is not now as to woman's ability to fill the office but merely one of taste and feeling. "I do not like to see a woman mixed up in politics," said one of the most intelligent members, "electioneering among all sorts of men, as she must do to obtain the office."

21 January 1878 


\section{Do not indulge in satire - no doubt you are witty but it matters little}

My third year at Oberlin, I became friends with a boy Daniel whom I met after a debate meeting. He had been terrible in the debate, short on facts, shorter on quick rebuttals, but he had a friendly face and was gracious in defeat, and I surprised myself afterwards by telling him he had done well.

"All these silly classes they make us take," he complained as we left the library. "What use will I have for solid geometry and Cicero when I am a minister?" Sigh-cero, he said.

"Cicero." I instantly regretted my words. No one liked to be corrected, much less by a woman.

He surprised me by laughing. "Maybe I should pay more attention in class."

Sometimes Daniel joined me in the Museum as I cleaned. Even with the door open, we were breaking the rules and for this reason, our talks had a tinge of excitement. Daniel hadn't wanted to attend college but his mother had insisted. He, like some of the more adventurous male students, planned to move to Wyoming territory after graduation. He had a romantic idea of the West, all the people out there he could save with his eloquent sermons. I knew he would need a wife to write these eloquent sermons since he often struggled with his schoolwork. Occasionally I would imagine I could be that wife for him, but mostly it was because I knew I would write excellent sermons.

"Women can vote in Wyoming," I said. "And not just in school board elections. The teachers, men and women, are all paid the same."

"So there's a lot to recommend it," Daniel said. "Maybe you will decide to teach there someday." When he smiled, his eyes creased at the corners in a way I liked very much. Sometimes I would feel him watching me as I cleaned, and I wondered if he was thinking there 
were worse people he could ask to write his sermons. This was not the love I had read about in books, the kind that made a woman swoon and flitter about like a bird drunk on berries, but there was an easy companionship between us. Most days, that seemed like a good enough reason to marry. If he asks, I sometimes thought, I will consider it.

"Don't you think it odd, that we can be trusted to clean the microscopes but not use them?" I asked him once.

"Using the microscopes doesn't strike me as a grand privilege," Daniel said. "I see no reason why you should be denied the boredom of Linnean taxonomy."

"I would love botany!" I cried. "You don’t know how lucky you are."

“Botany seems like a science women would excel at," Daniel said. "There's no killing, no dissecting, nothing that would overwhelm the sensibilities. In fact, it's not so different from flower arranging and flower painting."

I made a mental note to discuss with Miss Voght the possibility of a botany lesson snuck into Household Economy.

Once when I was running behind in my chores, I held out a rag to Daniel. "Help me clean the cases?" The boys had outdoor chores only once a week, to avoid disruption to their studies.

I suppose I was testing him. He looked surprised, but he did not take the rag from me. A friendly reminder that Oberlin was not Wyoming. 


\section{Never should a lady accept gifts from a gentleman not related or engaged to her}

At the end of my third year, I was returning slides to their proper drawers since someone (For use by male students only!) had failed to do so, when I looked up to find a male student standing in the doorway, watching me. I was so startled I nearly dropped the slides in my hands. Earlier, I had flagrantly broken the rules by peering into the microscopes.

He looked around at gleaming glass cases. "I've never been in here. All my chores are outside. With the animals." He did not look like he spent a lot of time outdoors with those shiny black boots on his feet. Later I tried to remember other things about him: his hair or his eyes. I can’t. Or maybe my mind won’t let me. But I do remember those shiny black boots.

He rested his hands directly on one of the cases and peered down at the plants inside. "What's so special about them?"

"Some are poisonous," I said. When he lifted his hand, I could clearly see the outline of his fingers on the glass.

His eyes took in my dress and face. "They wouldn't let girls clean the cases if there were poisonous plants inside."

Something in his voice made me instantly wary. "I must have been mistaken."

“I’ve seen you before," he said. "With that boy Daniel. Is he your beau?" He said beau in a teasing voice, but his smile did not extend to his eyes. "You were friends with that girl Sally who was expelled a few years ago. Expelled for -" here he tapped his fingers against the case as if thinking hard "moonlight wanderings, correct?"

I suddenly knew, as clearly as if he had said the words aloud, that he was one of the unnamed male students who had been with her that night. I'd often wondered what happened to the boys. 
"Girls of her class don't know better," he said. "It's a shame."

A silly and vain girl, Sally spent more time fussing over her appearance than her studies. "You could be pretty if you just tried a little, Ruth," she once said as we dressed for chapel. We might have become friends, or we might have merely been friendly with one another, but in November someone saw her out past curfew walking with two male students and I came back from class one day to find her half of the room empty. On our dresser she'd left me a locket of hers I often admired. Wear this and think of me read her note. The locket was in the shape of a fan and covered in delicate reeds and butterflies. I instinctively touched it now, hanging around my neck.

I was not finished cleaning the Museum, but I did not want to be in the room with him one minute longer. When I went to walk past him, his hand shot out and gripped my wrist.

Aunt Janna used to lament my big bones: How will we ever find dresses to flatter those thick arms? In his hand, my wrist looked like any woman's wrist, delicate and breakable. I had not noticed, as he was slouched against the glass cases, how very tall he was. "Let go. Please." I was embarrassed at the tears in my voice. "I want to leave."

"I won't tell anyone."

He pushed me against the table and several slides fell to the floor. One hand clamped over my mouth and the other fumbled under my skirts. This is what it feels like to drown, I thought, and then there was a sharp, searing pain, like I was being ripped apart, or in half, and the broken slides on the floor swam in and out of focus, the way objects do in dreams.

When he was finished, he threw his handkerchief at me. His shiny black boots avoided the broken glass on the floor as he walked out. I waited until I couldn't hear his footsteps 
anymore and then I closed the door. My hands shook as I wiped down the cases but I did not stop until his fingerprints were gone and the pain between my legs was a dull ache.

It was a nice spring day, cool but sunny, when I finally emerged from the Museum. I felt as if I were seeing the grounds for the first time. There were the tulips recently planted by the first-year girls. Garish flowers of red, yellow, and pink. I walked past the library, which I visited every Saturday when the boys were busy with their chores. Daniel often teased me that he rarely saw me without a book.

I had been told to want a husband and a family, and I did. I didn't want to live alone like Miss Voght. I also wanted to make my own way in the world. I was as helpless as an animal caught in a trap. Better to gnaw off my own limb and escape? Or quietly succumb to the inevitable?

Behind the library was the farm where the boys worked. Whatever they had to do there only took up four hours, one day a week. The more you act like a lady, the more he'll act like a gentleman read a sign in the dining room. All the things I would be and do if I were not held responsible for the behavior of others.

Aunt Janna had not understood my desire to attend college. She said it would lead to ruin, but it was my life to ruin. I saw, as if a piece of muslin had been suddenly lifted from my eyes, that she had wanted something different for me. She had not understood me, and she had not particularly liked me. But she had stayed after my mother and father died and had found the money for my schooling. What would she say if she knew what had just happened?

She would blame me, of course, as would the other students and teachers. They would say it was my fault, that I had encouraged him, tempted him. If he had not behaved like a gentleman, it was because I had failed to act like a proper lady. 
I passed a group of boys on their way to class. They were dressed similarly, same haircuts even, one indistinguishable from the next. It wasn't their fault they saw us Oberlin girls as interchangeable; no one had ever told them we weren't.

Back in my room, I climbed into bed with my shoes on. I was still bleeding, but I did not get a rag. I had already decided I would never wear this dress again.

The next morning I could still see the faint outline of his fingers on my hips. I did not remember doing so but I had carried home his handkerchief. I stared at it for a long long time. I would not be surprised if someone told me I stared at that handkerchief on the floor of my room for a full hour. Sally's locket was warm against my bare skin. Wear this and think of me. The look on his face as he threw the handkerchief at me, as if I were a speck of dirt on his boots, something to be stepped over and forgotten.

I snatched the handkerchief from the floor and hid it in my trunk. 


\section{The Courier Journal 22}

\section{CORSETS!}

100 dozen Double Bone Werley Corsets at $\$ 1.75$, worth $\$ 2.25$

50 dozen C.P. Corsets at $\$ 1.25$, worth $\$ 1.75$

50 dozen 100 Bone Corsets at 50 cents, worth 75

50 dozen Whalebone Corsets at 50 cents, worth 65

50 dozen Whalebone Corsets at 25 cents, worth 50

Having a large stock of Corsets on hand of almost every make, I am determined to SELL THEM

REGARDLESS OF COST. Ladies are invited to examine these goods, as they will be sold at the above prices for the next Thirty Days.

${ }^{22}$ May 1877 


\section{Never make noises with the mouth or throat while eating}

The morning of the Christmas Eve package reception, we wake to find the dining room overrun with flies. "Don't tell me this isn't bad luck." Maggie says. These flies are larger than any I've ever seen, and even I feel uneasy as I watch them traverse the room in lazy circles.

Matron instructs us to hang elder-bush in the doorway and leave vinegar-soaked cloths of cucumber peelings into the corners. Cora and Theresa stand in the middle of the room and swat at the flies with brooms. The sight of them, their bellies swaying as they chase the flies, sends me into a fit of laughter. Cora and I chase each other with the brooms and when we breathlessly collapse into the dining room chairs, we could be mistaken for any two women indulging in silliness before a party.

The afternoon is spent transforming the house for Christmas. The reverend delivers a tree to the Home, and we decorate it with strings of popcorn and cranberries. Matron sends us into the back garden for ivy to hang on the bannister and mantle. I hum a Christmas carol as I gather greenery in my arms, the pure pleasure of being outside and feeling the sun on my face. The cold air smells of evergreen and fire smoke.

Cora and Theresa bake cookies, and Maggie and I glaze the angels and gingerbread men with colored sugar. When Matron isn't looking, we all sneak a cookie. "I love Christmas," Cora says, biting off the wings of an angel.

Maggie taps Cora's stomach. "As do babies."

I laugh aloud at the surprised look on Cora's face, although later I wonder why I found that so funny. 
An hour before the party is set to start, the flies begin dying in earnest. Their bodies accumulate on the dining room table until it looks as if it's covered in black ink. We take down the elder bush, throw out the cucumber peelings. We sweep and sweep and sweep. "These flies will be the end of me," Matron says grimly. Out the dining room window, I watch a vulture swoop in and out of the trees across the street. I look behind me, but luckily Maggie doesn't see.

Kate has one more week of confinement before she will go work for Mrs. Kesselman, the secretary of the Board. After a few months of honest work, she will be given money to travel home with her babies. I find Kate sitting in bed feeding Sophia, who snuffles and flails her arms about as she sucks with loud smacking noises. William lies patiently in the cradle awaiting his turn.

I help her change the babies into clean gowns and I surprise myself when I run a hand across Sophia's head. Such softness. I prefer her feistiness to William's docility. It's easy for him to be placid since the world is designed to meet his needs. It's Sophia who will be forced to bend her will to others.

Matron has said Kate can attend the party for an hour, as long as she doesn't exert herself. We find a pink dress with green flowers that another girl left behind, and I tie a green velvet ribbon around her neck to make it more festive. She shows me the corset she has modified so she can feed the twins, the slits she added above and below the bust, which can be raised and lowered as needed. "Brilliant," I tell her.

"My mother taught me," she says. "I'll help you make one when it's your time." In her flowered dress, with her hair braided atop her head, Kate looks like the mother in a children's book. I turn her to face the babies. "Doesn't your mother look beautiful?" From the 
bed, Sophia squawks and caws while William lies there, silently gazing at the ceiling. She a songbird, he a hawk.

With the impending prospect of guests in the house, Maggie becomes agitated. She fusses with her hair, fretfully smoothing it down across her cheek. I think of my old barn cat, the one who didn't like visitors.

"I should lie down. I feel very unwell."

"Did you eat too many cookies?" Cora asks.

"Maybe the baby is coming." She is pale, sweating.

"You have another month, silly girl,” Matron says. Mrs. Davidson would not approve of the way she indulges Maggie's nervousness. "Go lie down, and I'll check on you later."

Maggie scurries away.

"Ruth, you greet the guests at the door. Cora and Theresa, you'll help me in the kitchen. Kate, go sit down with the babies so you don't get overtired. And girls? Don't speak unless you are spoken to."

Mrs. Kesselman is the first to arrive. A large widow with a loud voice, she has a series of moles running amok on her face. There's a large one beneath her nose, an even larger one stuck to her chin, a thick cluster on her cheeks. The one on her chin sometimes has a long white hair growing from it. Tonight the chin mole is hairless, thank goodness.

"Good evening, girl," she booms when I open the door. She hands me her coat and a pile of presents adorned with colorful ribbons made of yarn and gives my stomach a friendly pat as she walks into the sitting room. 
Mrs. Davidson and Minnie arrive next. Minnie is splendid in a purple velvet dress. In her bile green dress, Mrs. Davidson looks ill by comparison. The red beetle pin by her throat resembles a blob of blood. Minnie carries a large package which she insists on lugging into the house herself. Based on the way she staggers as she carries it inside, it's rather heavy. Mrs. Davidson hands me a thin package wrapped in brown paper and tied with twine. "For Matron's eyes only."

I am relieved when Mrs. Norris the Board treasurer arrives alone. Her husband has called me Roseanne, Rosie, and Rachel and his inability to learn my name has never prevented him from finding a way to squeeze my behind.

Mrs. Norris has a daughter named Ruth. Because of this, she once told me she says an extra prayer every night for me. "But don't tell the others," she added quickly. "I don't want to encourage rivalries." This other Ruth can't seem to stay pregnant - all of her pregnancies this year have ended in miscarriage. I shouldn't be, but I am envious of this other Ruth.

Tonight Mrs. Norris squeezes my hands between her small cold ones. Her wrists are the size of a child's. It's a wonder she was able to have a child herself with those slim hips. "Merry Christmas, Ruth dear.” 


\section{Do not intersperse your language with foreign words and high-sounding terms}

We sing carols by the piano and eat cookies. Cora plays "The First Noel" and "God Rest Ye Merry Gentleman." Her voice is high and sweet. All day I have seesawed between extreme emotions: joyful one minute, sorrowful the next.

“Is it time for presents yet?" Minnie asks when there is a lull. She doesn't wait for an answer but retrieves the rectangular package she carried in earlier.

"I made it myself." She leans the present against the end of the couch and stands with her hands on her hips. She looks as pleased as a child waiting for praise. "I thought it might brighten up the sitting room."

"How thoughtful of you, Miss Davidson," Matron says.

"I have no idea what she painted," Mrs. Davidson says to Mrs. Kesselman and Mrs. Norris. "She wouldn't let me see it."

"She wanted it to be a surprise for you too. Isn't that lovely," Mrs. Norris says.

“That's one way to see it," Mrs. Davidson says.

"Mrs. Whitehead, would you do the honors?" Minnie asks Matron, who nods and begins carefully removing the paper. "Go on," Minnie urges. "Rip it right off."

"Oh my," Matron says. She squints at the painting and tilts her head. "I've never seen anything quite like this." She turns it around so we can see it.

Kate coughs politely into her hands.

"What is it?" Cora asks.

"Impressionism. It's all the rage in Paris." Minnie beams at us. "I was inspired by a painting Monet did of a poppy field." 
It's as if someone taught Minnie to paint trees and people, but she forgot the specifics and instead decided to paint the idea of them. Yellow and green dots signify leaves and two blurry figures in hats stroll on a path. A red lamppost stands among the trees, and behind that is a gray building that I immediately know is the Home.

"It's incredible." It's the most honest thing I have said in months.

"I thought we could hang it over here." Minnie points to the spot beside Mrs. Davidson's portrait, which makes her mother's frown deepen.

"We've spent close to a small fortune on art lessons over the years," Mrs. Davidson says. "She used to paint the most beautiful landscapes."

"What did she call it?" Mrs. Kesselman asks. "Infantilism?"

“Impressionism. The artists paint outdoors. En plein air," Minnie says with a perfect French accent. "It helps them capture sunlight. I thought Mother would object if I tried to paint outside."

"She's going to Paris next in March to study art," Mrs. Davidson says. "She'll be studying under the Director-General of the Louvre."

Minnie tries to look modest but excitement practically radiates off her. How different my life would be, if I were Minnie Davidson. Expensive art lessons and trips to Paris, doting parents. I wonder, not for the first time, why it is that some are handed their dreams, with a bow on top, and others are forced to fight for every crumb of dignity.

We open the remaining packages to less fanfare. Mrs. Norris gives us lavender soap and new hair combs and Mrs. Kesselman gifts us white and yellow striped booties. "Nothing worse than a baby with cold feet," she shouts. When Kate slips them onto William, he wiggles his feet in a way that makes us all laugh. 
Mrs. Davidson presents Matron with a new prayer book for the Home, as well as a check. "That should tide you over for a few weeks at least."

Since Matron doesn't have her glasses on, I suspect she doesn't know the actual amount, but she exclaims over her generosity and says we will use the prayer book daily.

"Of course these girls still need to help with expenses," Mrs. Davidson says. "Sewing curtains is not enough. They should be mending garments and quilts as well. Especially now that there are twins."

"No harm in having a second," Mrs. Kesselman says taking her fifth cookie. She licks at the green glazed sugar coating her bottom lip. "I've always found twins to be rather frightening. Although admittedly these two appear rather even-tempered.”

"She can't take care of both babies, of course," Mrs. Davidson says.

Kate blushes. "My mother had twins. Three sets actually."

“Three sets!” Minnie exclaims.

"One baby would be difficult enough for a girl in her position," Mrs. Davidson says.

"They remind me of the puppies Father found in the church last spring," Minnie says as Sophia whines in her sleep. 'Look how the boy sleeps with his hands out like that. Isn't it charming, Mother?"

“Where's Maggie?” Mrs. Davidson asks Matron.

"Which one is Maggie?" asks Mrs. Kesselman. "I can’t keep all the girls straight."

“The girl with the unfortunate face," Mrs. Davidson says. "That terrifying scar that runs from here to here." She gestures from the top of her head to her neck.

“Maggie isn’t feeling well," Matron says.

“I hope she doesn't plan on having twins as well," Mrs. Davidson says. 
"Mother never eats sweets," Minnie says when Mrs. Kesselman offers the tray of cookies to her mother. She takes one for herself. "What beautiful hair the boy has. His sister will covet those curls someday."

"New girl," Mrs. Kesselman says loudly to Cora, "How are you adjusting?"

“The girls have taught me to sew," Cora says. "And I'm learning how to knit although it's terribly difficult."

"She's a quick learner," Matron adds.

“Taught her?” Mrs. Davidson asks. "She never learned?"

"Cora had an-" Matron pauses as if scanning through a list of words in her head, "unusual upbringing. As we discussed before her arrival."

"Do the babies cry a lot?" Minnie asks Kate.

"They're both sweet-tempered," Kate says at the same time Cora says, "Oh yes. Especially the girl. I'm surprised she's not screaming now." Matron gives her a look and Cora covers her mouth with her hand.

"I'm rather terrified of babies," Minnie says.

“Terrified? Surely not," Mrs. Norris says.

"Not the babies themselves. But childbirth. My friend Jane had a baby recently and she nearly died," says Minnie. "I visited her and the baby cried the entire visit, screamed and screamed until she was red in the face. My friend can't walk more than a few steps because she's in so much pain and I thought, Why the rush to get married?"

Mrs. Davidson shakes her head. "Minnie enjoys being provocative these days. It always works on her father, but I've found it best to ignore these outbursts. Women who speak as boldly 
and frankly as men generally find themselves alone and unmarried, but not by choice. Poor Mrs. George won’t even talk to me now, after the way Minnie treated her son.”

"I spared you then - you always say Mrs. George is a tiresome woman."

“But you mean to never marry?” Mrs. Norris asks Minnie.

"She lost her notebook and took it as a sign she shouldn't marry," Mrs. Davidson says.

How perfect that my theft of her notebook has been interpreted as a providential warning. I bite down, hard, on my lower lip to keep from laughing.

"This is why they caution girls against reading novels," Mrs. Davidson says. "It gives them strange, fretful ideas."

"I don't read novels, Mother. I read poetry."

"It clearly breeds the same overexcitement and peevishness."

"I will marry some day," Minnie says. "I have no intention of being a surplus woman. I simply haven't met anyone interesting enough to die for."

"What on earth is a surplus woman?"

"An old maid, Mrs. Kesselman."

"You see why my nerves are so frayed, listening to this kind of talk all day," Mrs. Davidson says.

"I've always thought it normal to fear death," Mrs. Kesselman says. "Not a day passes that I don't think of my sister Betsy and she died nearly forty years ago in childbirth. I still have the letters we exchanged when she was expecting. She was so worried something terrible would happen to her. And then her worst fears came true. Terrible!" she shouts in Cora's face who blanches.

Her loud voice wakes Sophia. Kate picks her up and paces in front of the fire. 
"What would she do if the boy were to start crying?" Mrs. Davidson asks. She has a way of asking questions to everyone and no one. It's a surprising trait in a woman.

"William rarely cries," Matron says. "But the girls are always eager to help each other. I'm sure you've noticed a great improvement in their manners and general bearing."

“They won't be under your watchful eye forever.” Mrs. Davidson fingers the beetle by her throat and studies William with a critical eye. "Boy babies are easier to care for. They sleep more and don't have any of the digestive issues that plague girls. Better dispositions as well."

"Ruth and her husband were hoping for a son, this last time," Mrs. Norris says. "The doctor fears she isn't strong enough to carry a child to term."

Mrs. Davidson makes a noise of sympathy. "It's dreadful to think of women like Ruth who pray every day for a child, while some girls have two at a time."

Before hearing about this other Ruth, I didn't know a woman might be unable to have children. It was like learning there were birds born without wings or cats without claws. All the things I tried to rid myself of this one: drinking tea laced with pennyroyal, tightening my corset until I couldn't breathe, exercising until my head spun.

Mrs. Kesselman leans over to Matron. Up close she smells slightly musty, like a shawl that needs a good airing. Rather than being unpleasant, it's a comforting, motherly smell. "How is she?" Her eyes dart over to Theresa who sits alone by the Christmas tree.

"She's still grieving," Matron says. "But I see an improvement."

“I'm glad you warned us about her hair. Atrocious." Mrs. Davidson pats her own hair, surprisingly dark for a woman her age. I've heard of women dyeing their hair with a steeped mixture of raspberries and wine, although it's hard to imagine Mrs. Davidson slathering such a mixture on her scalp. "You have been too indulgent with the girl. It's not as if someone cut out 
her tongue and she is unable to speak. She's making a choice to be obstinate. You must force her to join in conversations."

"She does all her chores and is a great help with the sewing," Matron says. "My mother used to say there was no wrong way to grieve."

Mrs. Davidson's expression makes clear she strongly disagrees with this sentiment.

“It's a terrible thing to lose a sister,” Mrs. Kesselman says. "After Betsy died, I blamed her husband. He moved to Ohio a few weeks after the funeral and by the end of the year he had married a girl there. A girl half his age," she says, and Mrs. Davidson tuts in disapproval. "They had six children. But that girl raised my nephew as if he were her own, I'll say that."

"You know, Ruth is from Ohio," Matron says.

"Which one is Ruth?" When Matron gestures to me, Mrs. Kesselman shouts in my direction: "Is your family still there?"

"Yes, I have an aunt in Cleveland."

"She must be sorry to see you in this state."

You are not welcome in my house in that condition was the beginning of her last letter to me. "Yes, very sorry."

"We've had quite a few ingrates pass through here." Mrs. Davidson looks over at Theresa. "A fair number of impostors and liars."

"In contrast, these current girls embrace all the opportunities they have been provided."

"You see the good in everyone, Mrs. Whitehead." Mrs. Davidson clearly does not see this as one of Matron's admirable qualities.

“Minnie dear, pass me another cookie, please," Mrs. Kesselman says. "No harm in having a third I always say.” 
"I hope you are referring to cookies and not children," Mrs. Davidson says. She looks down at William whose small chest rises and falls as he sleeps soundly. "Surely you weren't expecting her to bring two babies to your house when she comes to work. I don't see how she will get anything done."

Mrs. Kesselman swallows the bite of cookie in her mouth. "I hadn't considered twins when I offered her the job. The last girl - oh, what was her name? Agatha? Clara? She brought her baby with her."

"The last girl to work for you was Harriet," Matron says. "You were very pleased with her work as I recall. She recently wrote a letter saying she had married and was living in Lexington. Isn't that encouraging news?”

"Harriet, yes. I'm surprised to hear she married. She had that eye that wandered about, I never was sure if she was looking at me or something else. She had an appalling habit of sucking on the collar of her dress - what an odd girl she was. Of course you can't account for what men find attractive. But she was a hard worker. She brought the boy to work with her and whenever he cried, she would strap an old sheet to her back and carry the boy around that way. I never saw such a thing before although it did free up her hands to clean and cook."

"The girl won't be able to strap two babies onto her back," Mrs. Davidson says. "She's not a pack mule. I fear you'll be paying her to lounge about your house with two squalling babies."

"I was thinking that Kate would leave the babies here when she is working at your house, Mrs. Kesselman," Matron says. "Certainly we were surprised by the twins as much as you. But they are good-tempered and the girls can easily care for them while she is at work."

"Some babies cry endlessly when separated from their mothers." 
"Don’t be so gloomy, Mother," Minnie says.

"It occurs to me," Mrs. Davidson says slowly, "that we find ourselves in a fortuitous position. The girl has two babies and Ruth," she turns to Mrs. Norris, "has been wanting a child. There is an easy remedy sitting right under our noses."

Minnie laughs. “Oh Mother, be serious! You aren't suggesting that Ruthie take one of these babies?"

"That's exactly what I'm suggesting."

The room grows silent, as if sound could be extinguished as easily as a candle.

"She has two while another in this city has none. A girl in her position shouldn't be selfish."

“The babies are not puppies in a church, Mother. You can't divide them up as you please."

"As president of the Board, I am forced to make all sorts of uncomfortable decisions and it's clear to me the girl can't care for two."

By the fireplace Kate has gone still and white, Sophia clutched in her arms.

"There are lots of places in this city where Ruth and her husband can adopt a child," Matron says. "The Home of the Innocents, for example, is full of babies who need a loving home."

"One doesn't know anything about those children, what diseases they might carry," Mrs. Davidson says. "Most of them are cripples."

"I can take care of them. Both of them." Kate's voice trembles along with her body. "They're no trouble to me." 
"She's a friendless woman but the babies don't appear to be harmed by her." Mrs. Davidson lightly touches William on the foot and turns to Mrs. Norris. "Especially the boy. Wouldn't Ruth be a wonderful mother to him?"

"It's true Ruth would provide a good Christian home for a baby. I told her that if she places her trust in the Lord, she will find comfort and strength."

"I have a fiancé back home." Kate looks at Matron with drowning eyes.

Mrs. Davidson flaps her hand, as if Kate were a fly buzzing about the room. "He would have married her already. In fact, it seems very likely she will fall into the same life of sin she led before, especially if she leaves the Home saddled with not one but two children. How long before she ends up back in a house of ill fame?"

"Kate did not come to us from a house of ill fame," Matron says. "Now, why don't we go back in the other room and sing carols? Have a few more cookies?"

"The real problem," Mrs. Davidson says in a voice much louder than her normal one, "is that we never established a firm policy about the babies. It's been a bit haphazard, every girl choosing for herself whether to take her child or give it up for adoption. And now that we find ourselves with twins, we are truly in uncharted territory.”

I wait for Matron to say that twins are not uncharted territory for Kate, but she is silent. Kate makes a loud keening cry, more animal than human.

"Ruth could buy the boy and all this worry about how the girl will care for two babies, or how she'll work, will be settled." Mrs. Davidson smiles and pats Mrs. Norris's hand. "How relieved Ruth will be to finally have a child of her own. You told her to place her trust in the Lord and look what He has provided." 
"We are not in the practice of selling babies out of this Home," Matron says quietly. There is a firmness to her jaw that makes me realize I have never seen Matron truly angry before.

"Ruth and her husband can make a donation to the Home then," Mrs. Davidson says. "I will not allow such a transaction, Eliza."

Mrs. Davidson stiffens at the use of her Christian name. "A generous donation would alleviate costs, Mrs. Whitehead. And it bears repeating that you work for the Board. Reverend Davidson is one of your most loyal and faithful subscribers. Without our financial support, this Home would not survive another month."

"Ruth can take my baby.” Am I whispering or shouting? I don't know why it has taken me so long to speak.

"Ruth, no!" Kate is openly crying now.

“I don't want this child." I turn to Matron. "And Kate wants both of hers. It would be a help to me if someone took this baby and gave it a nice home."

“A help to you?” Mrs. Davidson asks. “All we do is help you girls! And how bold you are to decide that Mrs. Norris's daughter should take your child, instead of one of the twins. I'm not a mathematician but I can deduce that the girl can't care for two. Adoption is an easy solution to a complicated problem."

"Her name is Kate, not the girl. And she wants both her children, while I don't want this one."

“Are you planning on delivering two babies as well?” Mrs. Davidson asks. "As I recall, you came to us from college. I can't imagine that Ruth would want a child from a woman who wasted her time on such things." Mrs. Davidson turns to Cora with a fearsome smile. "What 
about you, dear? Will you be having twins as well? Do you also want us to take a child off your hands so you can return to a sinful life?"

"I'm not here to have a baby."

"Oh, my mistake. I thought all the women here were whores of Babylon."

I flinch, as if Mrs. Davidson slapped my cheek with that word.

“That's enough," Matron says. "I will not allow you to speak this way to the girls, even if you are president of the Board."

Mrs. Davidson's cheeks are the same mottled red as the beetle clinging to her throat. "I might as well light my money on fire and toss it out the carriage for all the good it's doing here. Our efforts have been in vain since girls of this class are unable to abandon their vulgar upbringing." She looks at Matron. "Especially if they are under the guidance of a fallen woman." Theresa moves soundlessly across the room and scoops up William from his cradle. She walks to the other side of the room and positions her body in front of the Christmas tree. Her short hair, aglow from the candles, is a fiery halo.

"Leave," she says to Mrs. Davidson. She switches William from her left to right arm. "Now."

Mrs. Davidson is momentarily speechless.

"You will not shop for babies as if this is a department store and you are in need of a new hat," Theresa says. "Go home."

Mrs. Davidson's neck is now a painful pink blotch. "The lack of restraining influences on display tonight. One girl ordering me to leave, one claiming she's not pregnant, one eschewing her maternal duties, and one refusing help. All that's missing is the scarred girl, and I shudder to 
think what insanity she might spout. There will be severe changes once the Reverend knows the true state of things over here.” Mrs. Davidson snatches up the prayer book and check.

"If you want to lecture about restraining influences, you should seek out Mr. Norris first." Theresa's eyes are dark as night as she looks directly at Mrs. Norris. "Ask him about the house on 4th Street he liked to frequent. He always requested Catherine and me together, the two blondies, he called us, never did bother to learn our names although it was obvious my sister was his favorite. He'll be sorry to hear she's dead."

Judging by her face, this is not the first time Mrs. Norris has heard such rumors about her husband.

Mrs. Davidson stands from the couch and gives Minnie a loud look. The girl meekly rises to her feet. "When I return tomorrow, I expect the girl to be expelled or I will close this Home myself. And if that one wishes to remain here," she turns to Kate, "she will give up the boy." Theresa gently cups William's head, runs a thumb across his forehead. 'I'll kill him myself before I let anyone separate him from his sister."

Kate is the first to spot the knife in Theresa's hand. With her left arm cradling William, Theresa's right makes the first gash, long and red. The second cut is deeper. I try to shout but something is wrong with my throat. Same with my feet, which refuse to leave the ground.

"They can't take this one now." Theresa makes the third and final slice before collapsing. 


\section{Never exhibit anger, impatience, or excitement when an accident happens}

Matron rips off the bottom of her own dress and presses it to Theresa's abdomen, where it promptly blooms red. I kneel helplessly beside Matron. "Ruth, I need rags. Go quickly."

I run upstairs and fling open the linen closet, blindly grabbing at the bandages. When I enter the sitting room again, I freeze at the sight of all the blood. It's in the branches of the Christmas tree, on Minnie's painting, on the fireplace screen. It's on William's clothing and his face. Kate has stripped off his clothes and wrapped him in a blanket. His cries appear to be of someone frightened, not hurt. Cora and Minnie sit side by side on the couch, both with stunned, blank faces. Cora reaches out and grabs Minnie's hand. Minnie looks down at their entwined hands in surprise but doesn't pull hers away.

The puddle beneath Theresa has grown larger. On the floor beside her is not a knife but Matron's letter opener, its handle no longer green.

I hand Matron one of the bandages and she presses down with both hands. I briefly wonder if she's using the bandage Rev. Davidson waved about during his Egyptian lecture. "We just need to get you stitched up, Theresa. And you'll be good as new." Matron motions for a clean rag and shows me how to apply pressure.

I press down on Theresa's stomach with both hands and hope I am not hurting her. She moans and blood slides from her mouth into her hair.

"You'll be fine, Theresa, you wait and see," Matron says. She presses a clean bandage against Theresa's stomach and ties it tightly. "Mrs. Kesselman, may we take your carriage?"

Mrs. Kesselman looks up at her name. Beside her, Mrs. Norris cries silently. "Yes, that's fine," Mrs. Kesselman says. "Mine is the largest." Her voice is no louder than a whisper. 
Matron looks at me. "On three," she says. It's hard to get a firm grip on Theresa, whose arms are slick with blood but we manage to lift her up and carry her outside. The cold air makes my eyes water, but Theresa doesn't react. She's gone slack in our arms, her head lolling off to the side in a way that I know is not natural.

"Wait," Mrs. Davidson calls. She rushes past with blankets in her arms. We wait in the cold, arms shaking with effort, as she carefully arranges the blankets over the seats of Mrs. Kesselman's carriage. She helps us maneuver Theresa inside and then Matron climbs in, cradling Theresa's head in her lap. "You foolish girl," she says, not bothering to wipe the tears streaming down her face. Mrs. Kesselman climbs in and they disappear into the night.

I am suddenly aware that I am covered in blood. My arms and dress are slick with it. Blood smells the same, no matter the reason it is leaving the body. I don't know why this should surprise me but it does.

When I finally told her about the baby, Miss Voght arranged a meeting with the president of Oberlin.

“There's no point," I said. "Mr. Bullough won't let me stay in my condition." "Mr. Bullough is progressive, surprisingly so," she said. "He recently formed a committee to look into opening more science classes to women." She patted my arm encouragingly. "Just because something has never been done before doesn't mean it's impossible, Ruth."

On the morning of our meeting, I scrubbed my face until it was pink and brushed my hair until my scalp tingled. I ransacked my closet for a dress that fit my new breasts. It was clear that 
Mr. Bullough had not dressed with the same care for our meeting - his wrinkled shirt had a yellowish stain on his collar, revealing a breakfast of eggs.

He ushered Miss Voght and me into his office. The surface of his desk was immaculate, and something about its extreme tidiness, not a stray paper or pen, no sign of dust, made my heart sink as I sat across from him. This was a man who clearly believed, at least when it came to his college if not his appearance, in the ordering power of rules.

I had never spoken to Mr. Bullough directly, but he was well-liked by both teachers and students. He was often on campus, sitting in on lectures and debates. He had fought in the war and there was something wrong with his hand as a result. His good hand now rested on top of the desk, while the other stayed in his lap.

"You don't believe you deserve expulsion, Ruth."

"It's not her fault, Richard," Miss Voght said.

He held up a hand in her direction. "I'd like to hear from Ruth, please. You are with child," he said to me.

"Yes. But not by choice."

He pressed together his thumb and index finger. The fingers on his good hand were unnaturally long and thin. Surely his wife had to make special gloves to fit those fingers. The hand in his lap was shriveled and scarred, more claw than hand. Did his wife make a special glove for that hand as well? "You're saying he forced you."

"Yes."

"That's a very serious accusation."

"I find myself in a rather serious situation." At a look from Miss Voght, I added, "Sir." 
Miss Voght's earrings, small blue stones, glittered in the light as she leaned forward in her chair. "Ruth is a smart girl and she's a good student. She's doing better in her studies than most of the boys in her year."

"I know," he said. "I looked over your grades this morning, and they are impressive."

In spite of myself, I fought to hide a smile. Instead I took out his handkerchief and carefully laid it on the desk. "He threw his handkerchief at me. Afterwards."

He looked at the initials sewn onto the cloth. The work of a mother or sister, someone proud he was heading off to college. "He'll say he gave it you," Mr. Bullough said. "Or that he has no idea how you ended up with it. Unfortunately a handkerchief proves nothing." Staring at it now, I saw how foolish it was as a piece of evidence.

"Ruth has not had any discipline problems, but I suspect that's not true of the boy," Miss Voght said.

"I can't ask him to prove that she resisted."

"Why not?" she challenged.

"Would you really drag Ruth through such a degrading process? Pit her word against his, allow her character to be examined and smeared, while his remains intact? I would be an unfeeling man if I allowed such a thing." He looked first at Miss Voght and then at me. "I wouldn't be able to look my wife or daughter in the eye afterwards," he said quietly.

"As long as you don't expel her, she can return after the baby is born."

"No."

"But Richard-"

"We must take the world as it is. Not as we wish it to be, Miss Voght." With his good hand flat on the desk, he pushed himself to standing. I focused on his claw-hand instead of his 
face. "I wish you luck, Ruth," he said. "There's a home in Louisville that I can inquire about, if you have nowhere else to go." 


\section{Never lend an article you have borrowed unless you have permission to do so}

In my dreams, I hear women crying but I can't find them. I fling open doors and the sound of the crying gets louder as I search room after room, all of them unfamiliar and vast. I move as if under water or walking through fog; how will I reach them in time? In time before what? my mother's painting asks me. I don't know, I don't know, I tell her.

When I wake on Christmas Day, it's from the sound of a crying baby, not a woman. The door to Kate's room is open, her bed empty. Sophia is alone in the cradle. I call for Kate and when she doesn't appear, I change Sophia into dry clothes. The door to Maggie's room is empty as well, the quilt from her bed crumpled on the floor. Maggie always took pride in keeping a clean room, and I swallow hard as I head downstairs.

A woman I don't recognize is on her hands and knees in the sitting room, scrubbing furiously at the rust-colored stains on the floor. She dips a wire brush into a bucket of strongsmelling water that makes my eyes and throat burn and moves the brush in small tight circles.

"Where's Matron?"

The girl doesn't look up from her work. "Kitchen."

I find Mrs. Davidson in the kitchen, Matron's apron tied snugly around her small waist. She walks past with a sack of sugar and places it next to a growing pile of food: leftover Christmas cookies, bacon, honey, pears, jellies. "Part of the problem," she says, as if we were in the middle of a conversation, "is the diet here. All these fatty foods."

Instinctively I pull Sophia closer to me. "Where's Matron?"

Mrs. Davidson opens and closes cabinets, peering inside. "There will be some changes around here. Dietary changes. Changes in chores. Which hopefully," she stands on her toes to pull down a tin of black tea, "will lead to significant changes in temperament and decorum." 
"Is she at the hospital with Theresa?" I ask this even though I don't think Theresa is at the hospital.

Mrs. Davidson returns to the cabinets without looking at me. "I know you were fond of Mrs. Whitehead but last night showed me what happens when there is a laxity of rules."

I shift Sophia to the other arm. She snuffles against my shoulder as if searching for food. She makes a whining noise that I know will escalate into screaming in mere seconds. "I can't find Kate, and her daughter is hungry."

"The girl is at the asylum. She refused to see the wisdom of giving her son a better life. Those who have made their beds must lie in them."

What I know of asylums comes from novels. They are not a place for someone like Kate. "You can't send a person to the asylum simply for disagreeing with you."

She stands up and wipes her hands on Matron's apron. "There is a devil-may-care tone in your voice that I don't appreciate."

I step away from her. "And Maggie?"

"The scarred girl is at the hospital. She went into labor early this morning and after what happened last night, I thought it best she stay there."

Mrs. Davidson bends down to look through the cabinets by the stove. I imagine shoving her inside, like she is the witch from Hansel and Gretel. I imagine snatching a knife and slashing at her the way Theresa did her own body. Then I imagine a different girl cutting out an article from the paper before pasting it in the black book: Two women sent to insane asylum, one to hospital, one to the city morgue.

Sophia begins crying, loud hiccupping sobs. Mrs. Davidson hands me a tin of powdered milk and a bottle. "I have a terrible headache. Please take her out of here." 
After breakfast, Mrs. Davidson's girl searches our rooms. In Theresa's, she finds an empty brown bottle and shears from the kitchen. When the girl brings down Minnie's book and lays it on the table beside the other contraband, Mrs. Davidson closes her eyes, pressing her fingers to her temple. "Where did you find that?"

"The room at the end of the hall, ma'am."

"My room," I say.

"Would you like to explain how my daughter's notebook ended up in your room?" "I took it."

"This means expulsion."

The moment is eerily familiar. Inevitable too. Third year girl expelled for curfew violation, reported the Oberlin Review. I suppose I should be thankful I'm not being sent to the asylum, but I'm too tired to feel much of anything.

Mrs. Davidson's girl packs my bag. She doesn't look at me as she hands it to me, and I don't look inside. When I hug Cora good-bye, I slip Dr. Munro's letter into her dress pocket. "This is yours," I whisper in her ear.

Mrs. Davidson walks me to the door. "I take no pleasure in your expulsion, Ruth. Especially not on Christmas Day." The door clicks shut behind her.

The coin doesn't land on tails every time, Ruth, Miss Voght said after our meeting with Mr. Bullough. I find comfort in the words today, even though I didn't all those months ago. It's statistically impossible for a coin to land on tails every time. 
It's cold outside but my body is warm, from my coat partly but mostly from the baby. No one told me that about being pregnant - the continuous warmth. How can I be a friendless woman when inside me is a constant companion?

I wonder if I will discover I am a cat who always lands on her feet, or if I am a bird who, once banished from the nest, falls to her death.

We must take the world as it is, Mr. Bullough said.

The world is ever-changing, sir, I would have told him, had I been a male student. My feet carry me towards the park.

Freedom smells the same, no matter the circumstances it is granted. This is not a surprise to me at all. 


\section{The Courier Journal ${ }^{23}$}

\section{An Interview with Venerable Worker Lucy Stone - What Women Want}

Though sixty winters have passed over the head of Mrs. Stone, she is still a hale and hearty woman, and expects to live to see the object of her labors, partially at least, accomplished.

$\mathrm{Q}$ - Is the cause of women suffrage gaining the interest of women?

Mrs. S. - Most assuredly, but they are slow to come out and acknowledge it in public.

Q - Do you expect it to be sustained in Wyoming, when she forms a State Constitution?

Mrs. S. - Certainly.

Q - What about in other Territory or States?

Mrs. S. - We don't expect anything, but we hope everything.

$\mathrm{Q}$ - Do you think that wives would be free voters?

Mrs. S. - Men who are tyrants now would be tyrants over the voting of their wives. And the sooner women get to respecting their own rights, the sooner their husbands respect them.

$\mathrm{Q}$ - If the wife is merely to duplicate the man's vote, would that be any gain?

Mrs. S - She will not duplicate it always. It would be a gain to have two votes for a good measure. $\mathrm{Q}$ - There is a general conviction that suffrage has been debased by too great extension into the ignorant and improvident classes; do you not think that woman suffrage, in its practical working, in which the worst would be sure to vote, and the better sort might neglect, would cause still further debasement? Mrs. S. - I am reminded of the man coming home late at night drunk. He says, "If my wife is up, I'll lick her. What right has to sit up so late at night? And if she's abed, I'll lick her. What right does she have to go to bed before I get home?" The opponents of women's suffrage are like this drunkard. They are equally dissatisfied whether the best or worst class of women vote.

${ }^{23}$ November 1879 


\section{A HOME FOR FRIENDLESS WOMEN - PART II}

The Home for Friendless Women minute books - September 9, 1889

Belle expelled 


\section{Admission}

This is not an inn on the highway of vice - you must be committed to leading a better life. The Drink Curse and the Social Evil are twin monsters and we cannot separate them. Do you promise to abstain from all intoxicants?

Yes ma’am.

Will you promise to stay in the Home for a full year? We have learned from experience that we cannot depend upon the stability of a reformation that cannot endure that long a test.

Yes or no? A head nod is not sufficient.

Yes.

Religion will not be thrust upon you. But we have found that all women, from their first day in the Home, intuitively turn to the worship of God. Do you promise to attend Sunday school twice a week and read from the Bible nightly?

I do.

Finally, you must agree to keep your child. This will hold you to a better life and act as a safeguard.

I agree.

While all the world might see you as incorrigible, we believe in your potential salvation. Now that you have heard about the drudgery and hard work, do you still desire admission? ${ }^{24}$ I'm no stranger to hard work, ma'am.

\footnotetext{
${ }^{24}$ Adapted from The Courier Journal - "Friends of the Fallen: A Charity the Fruit of Whose Good Work Will Ripen in Eternity," Feb. 26, 1887
} 


\section{How to make money: part 1}

Piano teacher

\section{Seamstress}

Laundress

Cleaning girl

Nanny

Note: Seduction and/or abandonment may occur. Apply at your own risk. 


\section{7 prostitutes killed}

Hattie gave birth the same day Mr. Goss was run over by his carriage in front of the Home.

Every Friday he left caramels for us in a white paper bag on the porch. He claimed they were the ones he didn't sell in his sweet shop that week, but the candies were too buttery and fresh-tasting to be a week old. When we saw him on our Sunday walk to church, he would wave: Did you enjoy the caramels, girls?

That particular Friday as he climbed out of his carriage, something spooked his horse and he was tossed to the ground. Mrs. Goss put down the horse that trampled him that same night; she said she couldn't bear to see it ever again.

When we retired to the front room after dinner for needlework, no one chose the chair by the window overlooking the street. Mr. Goss's body had been taken away hours ago but there was still blood and caramels in the street.

“Aged Man Thrown From His Carriage, Sustaining Probably Fatal Injuries," 25 Annie read aloud from the evening paper. She carefully snipped out the article with her sewing scissors. "Poor Mr. Goss.” Annie's favorite column in the newspaper was the Devil's Diary, an annual compilation of all the murders from the year: 57 persons killed by thieves, 253 men killed in common quarrels, 4 killings on account of dogs, 64 on account of wives, etc.

"He had a nice long life," Caroline said. She looked over at her son Phillip, lying placidly on a blanket beside her chair. "We can take comfort in that. I'd like to pray for him before we begin sewing." Caroline was new to religion and her prayers had an embarrassing earnestness to them.

${ }^{25}$ Adapted from The Courier Journal - Aug. 6, 1899 
"What could be worse than being trampled to death by your own horse?" Mary Ann asked after.

“It wouldn't be better if the trampling was done by someone else's horse, if the final outcome was still death," Annie said. At forty-eight, Annie was the oldest woman in the Home. Unlike the rest of us, she was not pregnant. Her daughter Tabitha lived in Tennessee and sent her a Christmas card every year. In her letters she called her Aunt Annie.

"Would you rather be trampled by horses or die in childbirth?” I asked.

“Oh Belle, really,” Mary Ann said. "Don’t be so gruesome."

"Horses,” said Annie. "A quicker death."

“Speaking of death, I received a letter from my cousin Constance today,” said Mary Ann. "It's been one year since that man in London killed all those women, and they still haven't caught him. Constance thinks they never will."

“And I'm the gruesome one?” I asked Mary Ann. It was a real struggle to be patient with Mary Ann. She claimed to be a widow although she clearly came from a house of ill fame, and I was good at spotting former fame girls, since I used to help Fay with the screening at her place. Girls like Mary Ann, whose figures were on the thick side or whose manners were a little too uppity, we sent to Hannah Daily's on Lafayette St. Fay said I was the best at sniffing out the girls who thought they were too good for the job.

The last time Mary Ann said she was a widow, I called her a liar and she cried until her face grew splotchy and she gave herself the hiccups. To be fair, I didn't call her a liar. What I said was "I don't care where you came from, but you're no widow." Miss MacCorkle and Mrs. Clarke grew worried Mary Ann's baby would come early because of all the hiccupping and 
carrying on, and after she calmed down, they were angry with me; the most infuriating part was they weren't angry with Mary Ann for lying. I apologized but I never forgot what she was.

“Of course Constance isn’t worried because this man in London only killed a very particular kind of woman. What some might call a doubtful woman.” Mary Ann squinted over at me. She desperately needed glasses but was too vain to wear them. "Isn't that terrifying, Belle?"

“Terrifying," I agreed. "It's doubly worse for those thick-skulled women who didn't realize they were a target for this man. Women who pretended they weren't ever a doubtful woman, as you say."

"Men murder women all the time," Annie said. "They murder each other and their own sons as well. You don't have to live in London to know that."

The last newspaper article about the Home included a paragraph about Annie: An interesting character occupies the room furnished by the Trinity Methodist women. Her former life of dissipation has bleached her black hair and given her a prematurely old expression. She is called 'Annie' and has been in the Home for over eight years, never having been beyond its doors during that time. ${ }^{26}$ Annie attended Sunday services with the rest of us, and her hair did not look any worse than most women her age, but I guess it made for a better story to make her a recluse with bad hair.

"The things this man did to those girls," Mary Ann said about the London murderer. "I'm still haunted by what Constance told me. How he cut them up, the parts he took and the parts he left behind." She smoothed the curtains in her lap. "I'll spare you the details. Don't bother asking. Bodies left in the street like garbage. Insides on the outside of the body. You don't want to know. I share a name with one of the murdered women. It's too shocking to dwell on."

${ }^{26}$ Adapted from The Courier Journal - May 29, 1894 
Hattie's screams drifted downstairs, and we fell silent. I had learned, from my time in the Home that labor changed a woman into an animal. I sometimes pictured my hands becoming claws, heat and pain coursing through me. What did a woman do on the other side of such a transformation? How did she ever walk around in the world the same way?

"Did he take their eyes?" Annie asked. Instead of sewing curtains, she was mending the quilt on her bed. Last month, the women of the Trinity Methodist Church donated new quilts to the Home, and Miss MacCorkle wanted Annie to trade in her quilt, with its strange colors and uneven squares, for one of the nice new ones. This quilt has been on my bed since I first arrived, and it will remain on my bed until I die, Annie told her.

Mary Ann nodded. "You also share a name with one of the women, Annie."

Annie didn't look up from her quilt. "I bet he took their wombs. Men like that always do."

Mary Ann made a slicing movement across her abdomen. "That's the last thing I'll confirm."

"My womb fell out years ago," Annie said.

I suddenly thought of the farmer from Carroll County. All those months later, I sometimes still woke in the night gasping for air, his fingers a vise on my neck. It took a week for the bruises to fade, and two weeks for my voice to return.

"If this man in London is ever caught," I said, "it will be because he tried to mess with the wrong woman."

Oh God come to my assistance! Hattie screamed. 
Women's Christian Work:

\section{The Treasurer's Annual Report on the Home for Friendless Women}

$\begin{array}{lrc}\text { General expenses } & 760 & 00 \\ \text { Matron's salary } & 220 & 00 \\ \text { Rent } & 339 & 00 \\ \text { Coal } & 50 & 00 \\ \text { Gas } & 8 & 40 \\ \text { Plumbing } & 5 & 00 \\ \text { Curtain stretchers } & 2 & 60 \\ \text { Cash on hand } & \$ 116.76\end{array}$

The health of the Home is thought to be good considering the broken-down condition in which so many of the girls enter our Home. The managers are at present occupied with the effort to raise money for the completion of a new building, which is to cost $\$ 24,000$ when completed. The report of the treasurer was read by Mrs. Edward Shippen. 


\section{Impressionism}

When I arrived at the Home in March, I spent my mornings working outside in the garden with the other women. The lady managers believed in the saving power of hard work. That and learning to make tasteful bouquets. Keep our bodies busy with work, so our minds became tractable and pliant. I was no stranger to hard work; I was open to the benefits of arranging bouquets. We must have resembled strange flowers ourselves, as we knelt in the dirt, our bellies as round as the bulbs we planted. And there was something pleasurable about watching the seeds we had buried in the spring grow and soar once summer arrived. Sometimes I would slip off my gloves and plunge my hands far beneath the sun-warmed top layer, to grasp something cold and solid.

For years I had been forced to unnaturally groom my body - no hair down below, abundant hair on top. A small waist. But not too small! A good-sized behind. But not too big! The trick was to appeal to the majority of men. An impossible task, really. And now my waist was not small and my bottom was too big and my hair was a riotous mess, and there was a dizzying freedom in this complete surrender of my body.

The marigolds that we planted beside the tomatoes failed to thrive, but the lilies burst open in an explosion of orange. When the rose bush finally bloomed, I wanted to cry. All that red was hard to look at straight on. The eggplant and carrots and lettuce did very well. One morning I came upon a squirrel holding a tomato; red flecks coated his fur as he bit into it like an apple. Snatches of a song ran through my mind that spring and summer: Enjoy the fragrance of thy prime, For oh, it is not always May!

That first month, the smells and sounds of the Home were too new to sleep through the night. Sometimes the nights were too chilly; other times I tossed my quilt to the floor because I 
was burning up. A person can learn to sleep anywhere, if there is a warm bed. The body needs what it needs but will take what is offered.

If I woke before dawn, I would thumb through the book on Kentucky birds Rose left behind at Fay's. I learned a lot about birds those first months in the Home. I had one of Rose's dresses with me and when I couldn't sleep, I would drape it across my stomach, and I talked to that dress as if it were Rose herself. How my gums bled when I brushed my teeth, that sweat collected under my breasts and behind my knees, that my swollen feet no longer fit into my boots. Her dress was a comforting presence there on my stomach, which rolled like the waves of the ocean we never did visit.

You cannot conjure a person's smell from their clothing, I learned. You cannot force yourself to remember all the forgotten details about them. If you're not careful, you can overhandle their memory, turning them into a person who never existed. Still, I clung to what I remembered.

Maybe the baby will have dark hair, like you, I said to Rose's dress on those sleepless nights. Your hazel eyes.

The real Rose would have said, It doesn't work that way, Belle.

But maybe that was exactly how it worked.

This home and Fay's place on $4^{\text {th }}$ Street were only three blocks apart. Fay used to tell us girls what to do with our hair and our bodies, and now Mrs. Clarke made the rules. I learned the sounds in the Home and at Fay's were not so different after all - moans and screams and cries. Oh God. Oh no. Sometimes I imagined telling Mrs. Clarke that, minus the religion lessons, her home wasn't so different from Fay's. 
My first week, I found a painting stashed behind the drying racks in the basement. The frame was old, rusted red in places. It was of two blurry figures on a path. I decided the figures were girls. These girls were not out for a leisurely stroll; their walking was purposeful and deliberate. But they were happy. Above their heads were yellow smudges. Hats or halos? Halos I decided. Ahead of them loomed a gray house. I studied that painting for a long long time before carrying it upstairs to my room.

"I don't think that's rust on the frame," Annie said. 


\section{The Courier Journal 27}

\section{Houses of Ill Fame: A letter to the editor}

I am writing, as the wife of a physician, to express my support for the amendment to the city charter which would grant licenses to houses of ill fame. While some have expressed doubt that this would curb the social evil in our midst, I believe a law could be framed to very much restrict it. All attempts at the extinction of prostitution - of which there have been many - present one unbroken record of failure. There are a class of impractical clergymen and a number of enthusiastic and well-meaning women who believe such an amendment, rather than suppressing the vice, would be seen as a protection and endorsement of this social evil. Two and a half million syphilis cases in the United States is of itself an argument cogent enough to overcome all opposition to the enactment of a law with an eye to public welfare. We can suppress the vice or we can continue as we have, and lament the increase of seductions,

illegitimacy, criminal abortion and infanticide. Much more can be said on this subject but I will close with the idea that the legislature could not pass a more beneficial law than one having, for its object, the regulation of houses of prostitution.

Sincerely,

Mrs. Edward Shippen

${ }^{27}$ Adapted from a letter to the editor in The Courier Journal - "Houses of III Fame," Feb. 8, 1888 


\section{The day of my birth, my death began its walk}

I passed Dr. Shippen the next morning as he was leaving Hattie's room. His sleeves were rolled to his elbows, his wrinkled shirt dark with sweat. The older girls speculated that his wife didn't iron his clothes. Most thought Dr. Shippen very handsome. He was tall, not fat, with kind blue eyes. According to Miss MacCorkle, he offered his services to the Home free of charge because his first wife died in childbirth. His current wife Regina was the treasurer for the Home. She was nearly thirty and still childless. Some of the older girls claimed to have seen her in town wearing men's boots.

“The baby's name is Joseph,” Dr. Shippen said. He briefly rubbed at his neck. "It was not an easy labor."

"Is it ever?" I did not know what I was seeking when I asked that. Not reassurance. I wanted more than comforting words; I wanted him to tell me that at age twenty-five, I would have an easier time than the girl whose screams had kept us both awake most of the night. What was the word for that kind of promise?

His eyes always struck me as more sad than kind. "For girls her age, no."

I pictured him walking home in the rain, his shirt darkening with each step. Once home, Mrs. Shippen would help him out of his dirty shirt and draw him a bath. Make his breakfast. Even if she didn't iron his shirts, she would want to care for him after such a long night. I'd known plenty of women who couldn't resist wanting to fix sad-eyed men. But this was a oneway road; in my experience, men didn’t feel a burning need to fix sad-eyed women. 


\section{But joyous?}

In the laundry room: Wash yourselves; make yourselves clean; remove the evil of your deeds from before my eyes and cease to do evil.

In the kitchen: But all things should be done decently and in order.

In the nursery: For God has not called us for impurity, but in holiness.

On an embroidered pillow in the sitting room, featuring a mother cradling her baby: He gives the barren woman a Home, making her the joyous mother of children.

The woman didn't look unhappy, exactly. 


\section{Some illness in the Home owing to defective sewage}

"Caroline, I believe you have some news to share," Miss MacCorkle said during dinner.

Miss MacCorkle had recovered from the stress of Mr. Goss's death although she had been too distressed to attend his funeral, and Mrs. Clarke said we could not go without a chaperone. A flock of friendless women descending would frighten his poor family, she said, and they have suffered enough. Did Mrs. Clarke picture us as a flock of yellow-rumped warblers? Ruby-crowned kinglets? Honking geese, more likely.

Earlier, Annie and I watched from the nursery window as Mr. Goss's friends filed in to pay their respects; I laughed in surprise when a group of geese alighted in the Goss yard and walked in clumsy circles amongst the guests.

"Girls used to say that tree in front of their house is haunted," Annie said.

"Did you know a white crow is the most unlucky bird you can encounter?" I asked Annie. I held Christie's daughter Augusta up to the window and she banged her small fist against the glass. "Bye bye," she said.

Caroline pressed her hands to her freckled face and blushed. "I received a marriage proposal today," she said.

“From a man who frequented Mollie's?" Annie asked.

Caroline came to the Home from Mollie Burns's, which used to be on Grayson St. Last year after an argument with a male companion, Mollie swallowed a two-ounce vial of laudanum and declared, "Death awaits me." According to Caroline, this was not unusual behavior for Mollie. An hour later, though, the unmistakable purplish color of poison stained Mollie's face and she grew insensible, which is how Caroline and the other girls came to be pallbearers at her funeral. That day Reverend Perkins shared with them the story of the fallen Magdalen. Though 
outcast from society and exiled from the better class of people, Magdalen was redeemed by Christ's love. After the service, Caroline asked Reverend Perkins if she too might be redeemed. We knew this story because Reverend Perkins shared it every time he came by the house. He even called Caroline "my Magdalen," which I found queer, to say the least. But not Caroline she said it was sweet.

"Oh no," Caroline said. "Fred lives in Jacksonville."

“Jacksonville? In Florida?” Mary Ann asked. "How does a man in another state go about asking for your hand in marriage?"

"We haven’t officially met," Caroline said. "But Reverend Perkins knows Fred's family and says Fred is a good Christian. We've been exchanging letters for a few weeks now. His wife died last winter. Childbirth.” She lightly touched her own stomach. "He has a daughter Phillip's age and a woman from town has been staying with him, but this woman's daughter is about to give birth in Kansas. He needs a wife and his baby needs a mother. Her name is Isabella. The baby, that is. Isn't that a lovely name?"

Caroline and her son Phillip were a strange combination. She was tall with a round freckled face and pale green eyes, while Phillip was squat with dark eyes and black hair. Even when she was days away from giving birth, her stomach remained small and high, as if she were smuggling a sack of flour under her dress.

“Shouldn't Caroline be seeking work here in Louisville instead of hunting down husbands in Florida?” Mary Ann asked with a frown. "Caroline won't have stayed the full eighteen months if she marries this man this year. Mrs. Clarke was very clear about the rules of the Home." 
Technically Miss MacCorkle was the Mistress of the Home, but it was Mrs. Clarke, her future mother-in-law, who was truly in charge. Mrs. Clarke clearly derived great pleasure from undermining her future daughter-in-law's decisions, disagreeing with her on everything from nursery wallpaper patterns - The babies will never sleep with such a busy pattern surrounding them, to how to decorate the sitting room - Didn't you know that fruit has taken the place of flowers in basket decorations? As for Miss MacCorkle's gardening attire - The less said about those bloomers, the better. Miss MacCorkle was unnaturally gracious when accepting Mrs. Clarke's advice; I couldn't tell if this made her wise beyond her years or quite stupid.

"Mrs. Clarke says it will be a real success story for the Home," Miss MacCorkle said. "A husband is always better than a job."

I laughed aloud. "I disagree," I said.

"But the rules." Mary Ann followed this with a loud hiccup.

"I sent him a sketch of Phillip and he said he was a handsome boy," Caroline said. "He said it was a great comfort to know I was a healthy woman who had not been weakened by childbirth."

Mary Ann stabbed one of the beans on her plate with such force the table shook. "What a glowing recommendation - you didn't die giving birth. I hope the older girls aren't offended by this blatant show of favoritism."

The girls nearing the end of their time in the Home, the ones who had given birth already and who had jobs in town, were known as the older girls. Their rooms were bigger than ours, their quilts nicer. They were allowed to spend their evenings making baby clothes instead of mending curtains. The three currently living upstairs - Rachel, Helen, and Christie - generally 
avoided us, as if our condition were contagious and we might re-infect them. Annie's room was also on the top floor but no one considered her an older girl.

"Rachel will be moving back home to Paducah to care for her mother, and Helen will return to Frankfort, where she will work as a laundress at the new Haly Buhr Hotel."

“And Christie?" Mary Ann asked. "Her time at the Home is drawing to an end and wouldn't it be better for her to have a nice Christian husband?"

Caroline looked anxiously from Miss MacCorkle to Mary Ann.

"Christie has been working with Mrs. Clarke to find a suitable place of employment."

"I heard Christie tell the older girls she wants to be a dentist," Annie said. "In New York."

“A lady dentist!" Miss MacCorkle exclaimed. "I can’t picture such a thing."

Mary Ann squinted across the table at Caroline. "Did you tell this man in Florida about your freckles?"

"No."

Well." Mary Ann took a sip of water, dabbed at her lips and hiccupped into her napkin. "Some men find freckled women very displeasing."

Caroline had tried various remedies to remove her freckles: sugar and honey, powdered borax, Friar's balsam and rose water. The sugar and honey mask didn't take off the freckles but, unlike the powdered borax, she said it did make her skin smell nice.

"Most men find malicious gossipmongers more displeasing than a few freckles on an otherwise pretty face," I said. A terrible thought suddenly occurred to me. "He's not a farmer, is he? I would not trust a farmer to take care of you and Philip."

"Fred works for the post office," Caroline said. 
Mary Ann viciously stabbed another green bean. Her hiccups were gaining speed. "Yellow fever is sweeping across Florida. And the things I could tell you about yellow fever would raise the hairs on your head, Caroline."

"We should avoid sharing medical stories at the dinner table," Miss MacCorkle said. "Now, Mary Ann, don’t get worked up."

"Maybe yellow fever isn't a problem where he lives," Caroline said.

"It's a problem everywhere in Florida," Mary Ann said. "But far be it from me to dissuade you." Hiccup. “Just because I personally wouldn't marry a man who wants to lure a poor hapless woman to Florida to bear him children doesn't mean that you should base your decision off anything I relay."

"Caroline might not get another proposal," Miss MacCorkle said. "It would be foolish foolish and foolhardy," she said earnestly to Caroline, "to throw away such an opportunity. Think how disappointed Reverend Perkins would be if you led on this poor man without any notion of marrying him. You told me yourself how despondent Fred has been since his wife died. Men are so helpless with children. I can't bear to think of little - what's her name again?"

"Isabella," Caroline said.

"What kind of woman might little Isabella become without a strong maternal influence?" "I'm glad you didn’t recommend me to this Florida man, Miss MacCorkle," Mary Ann said. "My cousin Ida has a friend Amelia who lives in Florida and Amelia told Ida that yellow fever is all anybody down there can talk about. She said that every night they burn tar fires outside the city limits to disrupt the miasma and that the smell of these fires is enough to make a person sick. Doctors are telling people that fear is more contagious than the fever and that worrying about death will only hasten it. If that's true, then poor Amelia will be the next to go. 
Ida said she frets about yellow fever in every letter. You don't want to hear how it ravages the body, Caroline." Mary Ann shook her head and a double hiccup slipped out. "First, chills. When I say chills, I mean a shaking so fierce your bones break. Then, vomit. Black and thick as tar." Caroline pushed away her dinner plate.

"We'd never be able to visit you and Phillip. Yellow fever is not something I will risk, even for a dear friend like you. I hope no girls from Florida seek shelter here. Imagine yellow fever sweeping through the house!" Hiccup. "Remember the diarrhea we all had last month? We'd long for that compared to yellow fever."

"To be honest," Miss MacCorkle said, "Mrs. Clarke is more worried about gossip running rampant in this house. She fears that's an incurable disease." 


\section{The Courier Journal ${ }^{28}$}

\section{A Protest Against Prostitution: A letter to the editor}

Will you allow us to add our hearty disapproval to the editorial you ran last week, on the subject of granting licenses to houses of ill fame? It is safe to say that every utterance in the aforementioned article will meet with the unqualified disapproval of religious and moral people everywhere. It seems shocking, in this enlightened age, to every lover of morality and pure life, that the city council of Louisville should even propose such a measure. The idea that the evil will exist and that we must, therefore, legalize it, is simply monstrous. Why not legalize and grant men the right to commit murder? As men will gamble in defiance even of law, why not grant them, under cover and protection of law, the right to gamble? Why bother passing laws to regulate disgraceful and degrading business at all? The proposition by the city council should be met by our own lawmakers with a stinging rebuke. They can afford to do nothing less. The Bible is full of denunciations of this evil and body-destroying sin that leads hapless men and lewd women to these places of destruction. Many strong men have been slain in these houses of cruelty and vice. Such establishments are, to speak plainly, the fastest way to hell.

Faithfully signed, Women of the Trinity Methodist Church

${ }^{28}$ Adapted from a letter to the editor in The Courier Journal - "A Protest Against Prostitution," Feb. 17, 1888 


\section{Surely there's more than one reason}

"You want to tell me already?" Fay asked in early February.

She was referring to the incident with Mr. Dreck, who refused to pay after I slapped his face when he went to touch my breasts.

"I would have understood if he had tried to touch your neck," she said. "But in my experience, there's only one reason a woman won't let a man touch her nipples."

"I don't know how this happened."

Fay made a dismissive noise.

I was lying on my back, focusing on the dimpled pattern in the ceiling to calm my stomach. "You should get that water stain looked at before the roof caves in," I said. I rolled over to face Fay and swallowed, hard, in order to keep my supper from coming back up.

"You'll have to leave when you start to show," she said.

"I'm not going to that religious Home you banished Ruby and Phoebe to last year."

"If you have a better idea, please share it."

"Abortion."

"You want to die like Evelyn?"

"I'll take those Spanish pills Charlotte has."

"Sugar-coated poison."

“They might work for me," I said stubbornly.

"So might motherhood," she said. 


\section{Happy birthday, dear Genevieve}

Miss MacCorkle studied the thermometer in her hands. "65 on the nose!" she crowed. "Mrs. Clarke said Leo is very sensitive to changes in temperature and that I should get in the habit of ensuring the bedroom remains a constant temperature. The last few mornings it's been closer to 69, which, according to Mrs. Clarke, is not an ideal temperature for men.”

Everything in Miss MacCorkle's bedroom was pink: the curtains framing the dressing table, the wool rug at the foot of the bed, even her quilt was a medley of dark and light pink squares. Her dressing table was covered with pink bottles holding hairpins, creams, and scent. Was the color scheme her decision or Mrs. Clarke's?

Stop asking the wrong questions, Belle, Fay would say.

Miss MacCorkle handed me a thick-handled silver hairbrush and sat down at her dressing table. 'It's from France. Horse hair. At the shop they said it's what the best hairdressers in Paris use."

Miss MacCorkle's hair used to be in dreadful condition - dandruff, greasy scalp, dry ends. All that was under control now but the bald spot right smack in the middle of her head had recently grown from nickel to half-dollar sized. Soon, no amount of combing and twisting would mask it. Last month I convinced her to try false hair, but she claimed it made her feel overheated and faint. "And what if it's the hair of someone in prison?" she fretted. "Or the hair of a youknow-what? I've read about such things, you know."

"A prostitute would never donate her hair," I said.

Miss MacCorkle's future husband Leo was ten years her senior, completely bald, and several inches shorter than her - and still she worried he would find her unappealing. 
The brush handle was cool in my hands. It had a pleasing heft to it; she had clearly spared no expense.

"Why is horse hair the best?" she asked as I started brushing her hair.

“Prevents breakage.” Everything I learned about hair, I learned at Fay’s. On Sundays we slathered egg whites onto our scalps to keep our hair shiny and strong. A girl once rinsed out the egg with hot water - lord what a mess she cooked up in her own hair.

"We have exactly one month until the wedding to get rid of that spot," Miss MacCorkle said anxiously to her reflection.

I massaged her scalp, applying light pressure around the thinning hair to stimulate blood flow. "At least Leo is shorter than you are. No chance of him looking down at the top of your head during the ceremony."

“Oh Belle, don't tease. The problem is all that time I spent attempting to curl my hair when I was younger. Sometimes my hair would smoke. What a terrible smell, burning hair. When Mary Ann was talking about the fires in Florida, that was the exact smell I thought of." She relaxed in her chair, closing her eyes as I brushed and brushed. "I used to have the most beautiful hair as a child. That's what Mother always told me."

For Miss MacCorkle's tenth birthday, the last birthday her mother was alive, her mother gave her a doll with a real silk dress. Miss MacCorkle said that doll's dress - pale blue, shimmery - was nicer than any dress she owned. She wasn't allowed to play with this doll, in case she ruined that silk dress. And you never once played with that doll? I asked her in astonishment. You never even took her out of the cabinet when no one was looking?

Never, she said proudly. 
It was hard to believe Miss MacCorkle and I were members of the same sex. I made a promise to my baby, there in Miss MacCorkle's pink explosion of a room, that I would never give him a present he couldn't enjoy.

She picked up a hairpin from the dressing table and ran her fingers across its amber colored surface. "Mrs. Clarke gave me this yesterday. It's tortoiseshell. She said the belly of the tortoise yields the highest quality jewelry. You'll never guess how much it cost. 4 whole dollars. She thought I might want to wear it at the wedding." She rubbed the gold top of the hairpin between her fingers. "I've never worn a tortoiseshell hairpin."

All the things I would do with $\$ 4$. And to spend it on a hair pin made from a turtle's shell. Mrs. Clarke was clearly as fool-headed as her bald son.

"But I wonder - is it the right accessory for such a special day? How can a girl be sure, on her wedding day, that she is ready to have such a pin inserted in her hair?" Miss MacCorkle said this in a rush, as if the words had been hiding beneath her tongue all morning.

"No woman likes having a pin inserted in her hair," I said. "Not the first time anyhow." "I'm very tender-headed. More so than most."

“Then you shouldn't be shy telling a man how you like to have your hair styled. If you would want him to brush your hair before he jabs in a hair pin, then speak up. Men aren't mind readers."

Try to be on your stomach the first time, a girl at Fay's told me. That way when you cry, he won't see.

"If a man doesn't like how his wife styles her hair, he might be tempted to visit an establishment where the women allow any old hair pin to be inserted into their hair. As long as the man is willing to pay." 
I'd always wondered what Miss MacCorkle knew about her fiancé's past. When I knew him, Leo was the piano player at Fay's every Thursday and Friday night. He'd probably still be there if he hadn't gotten it in his bald head that he was in love with Genevieve. He even proposed marriage to her. Once Fay heard that, she fired him on the spot. She said any man reckless enough to propose marriage to a prostitute was nothing but trouble, and her daddy used to say trouble rode a fast horse. And I won't be inviting trouble into my house so it can stampede around and destroy shit, she said.

If you were drunk and in a dark room, you might be able to convince yourself that Miss MacCorkle, with her pale, thinning hair and nervous blue eyes, resembled Genevieve. I thought of the song Leo performed for Genevieve's birthday:

Leo gave me apples, Leo gave me pears. Leo gave me fifty cents To kiss him on the stairs.

I gave him back his apples, I gave him back his pears. I gave him back his fifty cents And kicked him down the stairs.

“Have you ever been in love, Belle?” Miss MacCorkle asked now.

"No," I lied.

"I hope you're not jealous of Caroline. Maybe we can find you a husband too." "I'd prefer a job."

"You say the strangest things sometimes." She picked up her hairbrush and started plucking at the pale hairs caught in the bristles. "Leo told me about that nasty girl. The one at Fay Sewell's. How she led him on and teased him mercilessly. What a vulgar name. Genevieve." "She's married now. She's no threat to you." 
She suddenly swept all the hair pins off her dressing table onto the floor and met my eyes in the mirror. Her eyes were dangerously wet. "Pick those up."

“Careful, girl.” I didn’t know which one of us I was talking to.

But I was careful when I left, all those pearls and sharp gems at my feet. 


\section{Purify me with hyssop, and I will be clean}

The shelf above the washer held boxes of James Pyle Pearline soap. Forty-seven boxes to be exact. A former inmate married a relative of Mr. Pearline and now Mrs. Cora Pearline sent the Home a crate of laundry soap every year. It is my sincere desire that future girls will see these boxes of soap and be reminded that they too can be washed clean in the blood of the lamb.

The soap promised to remove stains with no rubbing whatsoever. I never tried this no rubbing method, although based on the numerous stains on the shared baby clothes, quite a few girls before me did. The piles of laundry in the Home never diminished; wash one load, and three more appeared, a predictable incoming tide of dirty linens, diapers, a sea of threadbare dresses. There were some chores I balked at but never laundry. It was the only place in the Home where I could be alone. Think in peace.

To remove blood stains: Submerge the clothing or bed sheets in boiling water with an ounce of cream of tartar and an ounce oxalic acid. Wait two minutes and then rinse with cool water. If the stain is stubborn, make a paste of soap and starch, spread it thinly on the blood and scrape off when dry. The day after Mr. Goss died, Annie spent the morning attacking the spots in the street with a scrub brush and a bucket of watered down Pearline soap.

A memory: age 10, helping Mother with laundry. I was the only girl in the family, a surprise baby, conceived after the war. Your father wasn't always like this, my mother would say, which didn't mean anything to me. Who was he, if not a man who startled easily, ate mostly white foods, and drank amber-colored liquids? I learned to never, ever enter a room without announcing myself.

There are women who think the world owes them something, my mother said that day as she scraped shavings of soft black soap into our washtub. The water steamed and shimmered 
blue, then gray. My mother and I shared the same thick hair, the same strong arms. And others who don't think they deserve the scraps they are given.

My mother said another baby would surely kill her and not long after my eleventh birthday, it did.

I thought a lot about what my mother told me that day. Someone like Miss MacCorkle might have heard the message, Remember your place. Don't expect too much and you won't be disappointed.

But I heard something different and over the years, it proved to be a better gift than a fancy doll: The world will only treat you as good as you treat yourself.

After my mother died, I answered a help wanted ad at a laundry in town, and when I turned sixteen, I rented a room above the laundry. I didn't know how to sleep, that first night, in the too quiet room. I opened the windows so I might feel surrounded by others, and my lullaby on those nights was the sounds of a busy street. When I thought about those years, it was like hearing a story about a stranger who shared my name. That Belle was very brave. She quickly learned that lonely and being alone are not the same thing at all.

It's not always possible to view your life from afar, to see how small decisions add up to something larger. This must be why we whisper our lives in the dark, why we ask someone else to receive what we once fiercely guarded in the silence of our hearts. If this is my life, how did it end up so different than I imagined?

When I was nineteen, a woman brought in a silk handkerchief dress. She wanted to know if I could remove the grease stain on the right sleeve. It was the nicest dress I had ever seen, much less touched, but I said yes with a moment's hesitation. When Fay Sewell returned the following day, she examined the sleeve from every angle before giving me $\$ 4$ and a job offer. 
That day, I traded my cramped room above the laundry for a room in a mansion on $4^{\text {th }}$ Street, and that night I let a man enter me for the first time, and after he left, I tucked the crumpled bills inside a pair of flannel stockings. It was more than a week's wages at the laundry. I filled up one pair of stockings and then two more.

If you didn’t think the world owed you something, good luck surviving. 


\section{Dear Sir:}

Can you please deliver this letter to the person who wrote the article on December 21 "May Lead a Better Life: Wealthy Farmer from Carroll County Marries A Fallen Woman"? I'm looking for the woman who married that man because she's in danger. Do you know their address in Carroll County? Do you know how I can find her? Send a response to Fay Sewell's, 624 Tenth Street.

Thank you,

Belle Queeney 


\section{WANTED: A girl about sixteen years of age to look after children}

From somewhere in the house, a baby was crying. Hattie looked with dismay at the food on her tray: mushy oatmeal, boiled potatoes, a glass of milk. It looked like a meal my father would enjoy. Mrs. Clarke believed new mothers should eat a bland diet to regain their strength and calm their nerves.

Hattie's room was stuffy and sour-smelling, a stew of sweat and old milk. I breathed through my mouth as I went to open the window. It had started raining again. Ten days since we had seen the sun.

“How do you feel?”' I asked.

Hattie's face was creased from the pillow. When she looked at me, the whites of her eyes were threaded with red.

The crying grew louder, more shrill. I peered into the cradle beside her bed.

"Where's Joseph?"

“They thought I wouldn't notice what they did to him. But I'm not stupid.” Her eyes flickered over to the closed closet door.

A naked and red-faced Joseph lay on the hardwood floor of the closet, the blanket underneath him wet.

“Come here you, it's okay,” I murmured. His cold and damp body writhed and wriggled. "Hattie, why is he in the closet?"

"He hates his cradle. He cries and cries when he's in there."

"Babies can't sleep on the floor. He needs clothes and a blanket."

"He doesn't like clothes. He cries when he has them on." 
"Babies cry," I said, wrapping him in a clean dry blanket. He scrunched up his face and cried louder as if to prove my point. "They also cry when they're hungry. When did you last feed him?"

Jagged wet spots bloomed on the front of her nightgown in response. She wordlessly lifted her nightgown. Dried blood crusted her nipples. Joseph made a noise that was part sigh, part squeal as he clamped down on her nipple. She grimaced as he began sucking in earnest.

Hattie had only been in the Home a month before giving birth. A quiet girl, with heavy eyebrows and a solemn mouth. I overheard Mrs. Clarke tell the doctor who brought her, that this was it, the absolute last time. Keep your money, she said. Because if you attempt to bring another young girl to this Home, I will make sure your reputation does not emerge unscathed.

"I think there's something wrong with my milk. He spits it up after he eats."

"Are you patting him on the back afterwards, the way Caroline showed you?"

"Maybe it's poisoned."

"Your milk isn't poisoned."

"I'm so tired. I'm so tired I forgot how to cry." Tears dripped down her face and fell onto Joseph's head. He stopped nursing in surprise, and a thin stream of milk dribbled out of his mouth. 


\section{The Courier Journal ${ }^{29}$}

\section{Women and politics}

It is difficult to speak with calmness and courtesy on the subject of woman's suffrage because the insults offered to the vast majority of women by its advocates have worn out their patience. Women are told they oppose suffrage because they are ignorant, because they are slaves. All the arguments in favor of woman's voting are puerile and silly; we would indeed be ignorant to be influenced by them. Suffrage as a natural right? No. It is a duty which society imposes upon such citizens as she sees best. The expression which arouses the greatest ire in the hearts of women generally is when the advocates of woman's suffrage claim to be 'fighting for our homes.' It is uncharitable, perhaps, but other women can't help wondering, as they see said advocates continually wandering to and fro upon the earth, whether they have any homes worth saving, and if they have, why they do not stay in them occasionally.

-Emma Walton Clarke

${ }^{29}$ Adapted from The Courier Journal - "Women and Politics," May 13, 1888 


\section{How to make money: part 2}

"My cousin Irene sent a letter today," Mary Ann said.

"I don’t want to hear more news about murdered women," I said. "And when you talk about your cousins, you stop sewing. Mrs. Clarke is coming on Friday to pick up the curtains and without Hattie to help, we're falling behind." Earlier that evening I had tried to coax Hattie downstairs. You don't have to sew, I told her. Just come sit with us downstairs - a change of scenery would do you and Joseph a world of good. And you know Annie loves snuggling new babies.

Not tonight, she said. But for once she wasn't crying, and neither was Joseph, which I took to be a good sign.

"We can't possibly be behind," said Mary Ann. "I've never seen a woman sew as quickly as you do."

"Compared to you, everyone is a fast sewer."

"In the time I have been here, we have repaired 853 garments, mended 2,617 pairs of lace curtains and made 65 quilts," said Annie.

"I don’t know how you know that, Annie, but I believe you," Caroline said.

Mary Ann held up the needle in her hand and made a show of sewing the striped curtains in her lap. "Constance lives in London. This letter is from Irene, who lives in Washington. In her letter, she told me all about a delightful new game she's been playing with her friends."

When I was inclined to feel sorry for Mary Ann, which was not often, I would wonder why she hadn't been invited to live with one of these many cousins during her pregnancy. Why did her family send her here, where she was forced to sew curtains with us every night? 
Mary Ann pulled the letter from her dress pocket and held it underneath the lamp's flame to better read the cramped writing.

"You're going to end up with wrinkles squinting like that," I said.

She ignored me, moving the paper dangerously close to the flame: "My dearest Mary Ann, I wanted to let you know about a new kind of game that's all the rage in Washington. Bean bag parties! Society belles are becoming very expert at this new game. At one end of the parlor is placed an inclined board with a square hole in it. Standing at the other end-and the further away from the board the more fun there is in the game - the players pitch ten bean bags toward the hole. A regular score is kept, and if the ten bags fall in the hole, it counts 100 or ten for each bag. Another bag, double the usual size, is also provided, and if this is also thrown into the square opening it adds twenty, making 120 the highest possible score. Should any of the bags remain on the board they count five points apiece, but for every bag that is thrown upon or falls to the floor, five points are subtracted. The big bag, or Jumbo, counts double or ten in each case. I have become quite expert at pitching these little bags. You would be astonished at my excellent skill in accurately gauging the distances and the strength necessary to be exerted! The sport is full of interest and bean bag boards are now found in every fashionable household which expects to be considered up to the times. ${ }^{30}$ I wish you could see how handsomely embroidered my Jumbo bag is."

Mary Ann dropped the letter into her lap with a sigh. "It sounds like enormous fun." "What kind of beans go in the bag?" Annie asked. "Kidney? Navy? We have a surplus of black-eyed peas in the Home, but those might not be considered a bean."

Mary Ann waved her hand impatiently. "The type of bean isn't important." "Of course the type of bean is important," Annie said.

\footnotetext{
${ }^{30}$ Adapted from The Courier Journal - "Woman's World and Work: A New Game for Young Ladies," Feb. 12, 1888
} 
When Annie was a child, her mother would give her a jar of beans in the morning and tell her to sort them by color before bedtime, and then at bedtime, she would watch as her mother dumped the beans back in the jar for the next day. Once I came across a half-black, half-red bean and I knew it was there as a test, Annie said.

A test of what? I asked.

A test, she repeated with conviction, and I didn't ask again.

"What I wouldn't give to have a bean bag party here," Mary Ann said with another sigh. "I would embroider my initials in red thread on my jumbo bag. To prevent cheating."

"I would never cheat at bean bags," Annie said.

"Maybe Mrs. Clarke would allow us to have a bean bag party here," Caroline said.

"We could have one to celebrate your wedding," Annie said.

Mary Ann pressed her lips together and rapidly moved her finger up and down between her nose and mouth.

"What on earth are you doing?" I asked.

"Pretending to sew a button onto my mouth so I will not say another word about this marriage proposal. It's clearly none of my business."

"It would make more sense to simply sew your mouth closed with thread, and forego the button altogether," Annie said.

"I'm going to tell him yes," Caroline said. "There's no need for anyone to sew their mouth shut." At Mary Ann's urging, she had applied lemon juice to her freckles and for the last two days, the skin on her cheeks was a sea of tiny red and white bumps.

"You'll be forever in his debt," Mary Ann said. "Every time you disagree with him, or he's unhappy about your cooking, he'll say, 'This is what I get for marrying a fallen woman.”” 
"I'm a good cook," Caroline said. "I rarely disagree with people. And to call me a fallen woman every time he's angry with me would be unkind. I deserve forgiveness too. Reverend Perkins says even the lowest among us deserves forgiveness."

Reverend Perkins said a lot of things to be honest. That man certainly liked to hear himself talk.

"I disagree with Reverend Perkins," Annie said. "Not about forgiveness," she said when she saw Caroline's look of shock. "But about calling you his Magdalen. Did you know Mary Magdalen is mentioned fourteen times in the Bible, and not one of those fourteen times is she called a prostitute?"

"The disciples would never have used that word," Caroline said.

"But they don't call her a woman of the town or a courtesan either. She didn't came from a brothel or bawdy house, sporting house, bagnio, house of ill fame, dive, or assignation house. I don't think she was a fallen woman at all."

"What do they say about her then?" Mary Ann asked.

"That Jesus drove seven demons out of her."

"Well there you go," Mary Ann said. "That was their way of saying doubtful."

"Is she truly mentioned fourteen times?" Caroline asked Annie.

"And in eight of the fourteen mentions, she is named first."

"She was important, then," Caroline said. "Doubtful woman or not."

"We are doubtful women doubting that Magdalen was a doubtful woman. Say that ten times fast."

“Oh Belle really,” Mary Ann said but even she laughed. 
Hattie suddenly appeared in the doorway. She was naked except for Joseph's baby blanket which she had tied tightly across her soft stomach. Water from her hair dripped onto the floor and mud coated her arms and legs. "They tried to poison my milk," she said grimly. "But I took care of it." 


\section{The angels of life and death wrestled over him}

Dr. Shippen said that what happened with Hattie, while rare, was more likely to occur in single women whose babies were male. As he talked, his wife stared at our stomachs with barely concealed horror.

"By the grace of God alone," Caroline said. During the service, I watched as she pulled a long strip of dead skin off her inflamed cheeks. The new skin underneath was just as freckled, poor girl.

The day of the funeral was breezy and sunny. Thanks to the relentless rain and humidity, my dresses had clung uncomfortably to my stomach for weeks. Sinful or not, I was happy to be outside, soaking up the sun. We shielded our eyes from the bright sun as Reverend Perkins spoke about life everlasting and forgiveness. Today was not a day to talk about fallen Magdalens. Inside me, the baby shifted from side to side, as if trying to get comfortable. If only this baby could stay inside me for years, so I might protect him from everything the world would throw at him.

Life everlasting I could accept. But forgiveness?

The older girls had not wanted to attend the funeral, but Mrs. Clarke insisted. Annie stayed home with the babies. The night before Joseph's funeral, Annie cut out an article from the paper. She slid in into her mouth, chewed, swallowed hard.

It was about Hattie, she said.

"My cousin Victoria had a similar episode after giving birth to her sixth child," Mary Ann said after the service. "When she got out of the asylum, she was quite stout." Any other day, I would have laughed to hear Mary Ann, of all people, label someone stout. 
"Through grace we learn to love the unlovable and the unlovely," Caroline said. I didn't know how she could say or believe such a thing anymore; she had been the one to find Joseph's body.

As we left the cemetery, Mary Ann held onto my arm. I couldn't tell if I was holding her up or if she were holding me. She led me over to a gravestone.

“That's my cousin Oscar," she said. Her face was a calm blankness. "He said we would marry. You can believe something is true, even if doesn't happen. He shouldn't have been allowed a Christian burial, but our family has money."

"I'm sorry." This time I meant it.

The cemetery was a sea of gravestones. So many Marys and Elizabeths, Johns and Josephs beneath our feet. They were remembered as devoted mothers and loving wives, adored sons and beloved husbands. Who would remember me in death? In spite of the many unlovable and unlovely things inside me, I too had once been someone's beloved.

I paused before a grave marker with the names of two women. Hazel Lawson and Lillian Eckard. Dear friends until the end.

Only then did I allow myself to cry. 


\section{The Courier Journal ${ }^{31}$}

\section{Medical}

The only perfectly safe and effectual remedy for female irregularities, Dr. Bernardo's Spanish Female Pills are compounded from ingredients known only to Dr. Bernardo, the famous Spanish Physician. Thousands of ladies in the U.S. are using them regularly and pronounce them Safe and Sure. Those who have used them recommend them to friends. Youth, health, and beauty retained by their use. Agreeable to the taste; purely vegetable; prompt in effect. Price $\$ 2.00$ per package. Sent by mail in plain wrapper, securely sealed, to any address. Remember Doctor Bernardo's Spanish Female Pills are the only reliable pill for female irregularities. Mention this paper.

${ }^{31}$ Adapted from The Courier Journal - August 1, 1890 


\section{The bride passed out cold: part 1}

On her last day at Fay's, Rose told me she couldn't have children. She teared up when she revealed this, while also admitting it was lucky, considering our present circumstances. "But I would make a good mother," she said.

"How do you know such a thing?" I was asking about her inability to have children, not the good mother part.

"I just know," she said, and then she was quiet as I kissed the places on her face where her tears had fallen.

The other girls were gone for the day, a shopping trip for new boots and gloves followed by sledding at Central Park. December was a notoriously slow month. Leading up to Christmas, men were more likely to spend money on gifts for their family; it meant we had the whole day to ourselves. We lay in bed and talked.

"Do you ever worry that we will never believe we have enough money to leave?"

"No," she said with a shake of her head. "We'll know it when we have it."

I told her that I wanted to live somewhere so cold we had to pile blankets and thick furs on the bed to stay warm. She wanted us to live somewhere sunny, where we could have an orange grove and swim in the ocean.

"You know that song Gathering Shells from the Sea Shore?" She hummed a few bars. "That's the first song I ever learned by heart on the piano." She said that as a child, she asked her uncle if the Pacific Ocean looked like the Ohio River, and he told her it was a color she'd never seen before, not exactly green, not exactly blue. He said ocean water was as different from river water as a crimson finch was from a cockatoo.

"Trust me," she said, laughing at my face, "they're very different birds." 
Before lunch, I stretched her out on the red velvet divan, the one Fay insisted was for customers only. "It's soft but not terribly comfortable," Rose said.

“That's what some men say about my pussy," I said, and I felt in in my chest when she laughed.

"A man better not say that in front of me," she said, and then it was my turn to stretch out on the sofa.

Afterwards she sat in front of the piano. "Why doesn't anyone play?"

"Leo used to play on Thursday and Friday nights. But he fell in love with one of the girls, and Fay didn't want that kind of trouble."

"Which girl?"

"Genevieve. She later married a man who bought her two hummingbirds as pets. She invited us over after her wedding and the birds were flying all about the parlor. They built their nests in the lace curtains. Every day, the florist brings her a basket of flowers so the birds can drink the honey."

"Every day?"

"Every single day. Her husband said that as long as the birds made her happy, they could build nests all over the house."

"He sounds rich."

“Old too."

Her fingers explored the piano keys. In her quiet confidence and skillful playing, I saw the piano lessons her uncle had paid for.

Maiden, that read'st this simple rhyme,

Enjoy thy youth, it will not stay; 


\section{Enjoy the fragrance of thy prime,}

For oh, it is not always May!

"Hello?" a male voice called from the foyer. "Hello? Is anyone here?"

Rose quickly closed the piano. She squeezed my hand - once, twice - before arranging herself on the sofa. I sat beside her. A big man in overalls stopped abruptly in the doorway to the front room. Straight away I noticed his eyes, one of which watered painfully.

“The door was unlocked," he said. "I didn't know if it was all right to come in.” His hands were red and chapped, as if he had been doing laundry all morning. He clasped them behind his back before sliding them into his overall pockets. "I'm not from here. I read about this place in the sporting guide."

I knew the entry he spoke of: The house at No. 157 is kept by Fay Sewell and has seven ladies in attendance ready to receive gentleman into their tender arms. The house is conducted in the best manner and is first class in every rate. When the new sporting guide came out, Fay brought us all new dresses in celebration.

“Where are you from?” Rose asked.

He drummed his fingers against his thick legs. "Carroll County. I'm a farmer there. I live alone."

Of course you do, I thought sourly. I could feel the beginnings of a headache from the wine I'd had at lunch. I was not in the mood for this man to interrupt our day of freedom. Men from out of town sometimes felt a little too free in their demands; you had to be firm with them.

"I like that skirt you're wearing," he said to Rose. "It looks very soft."

She stood up. "It's velveteen. Would you like to touch it?" 
He sank to his knees and crawled over to her. He lifted her skirt up and settled it around his head. I knew exactly how Rose's skirt felt and smelled when settled around your head. "Oh yes," he said from under her skirt. "It's the softest thing I ever felt."

Rose looked at me and made a face. "Shall we go upstairs?"

He crawled backwards to get out from under her skirt and nearly knocked her over. I instinctively reached out to catch her and she squeezed my hand in thanks. "Marry me instead," he said. He thrust those red hands in front of his face and pleaded. "I'll go crazy if you don't."

Rose had that kind of effect on men.

He dabbed at his eye with a not so clean handkerchief as he kneeled at her feet. "A good girl good like you shouldn't be living this sinful life. I'm a rich farmer, I'll make you happy, you'll see." He didn't seem aware I was in the room; he certainly wasn't concerned about my sinful ways. "Tell me your name at least."

"Marian." She caught my eye, and I offered her the smallest of smiles.

"Marian," he said. "Marian with the face of an angel. Marry me, Marian."

She walked over to the staircase and held out her hand to him. "Why don't you come upstairs with me?"

"You're not a sinful girl. I can tell that about you. Don't you want to get married? Don't you want a better life?"

She beckoned to him again.

He pounded the floor in frustration. "I'm.Not.Moving.Until.You.Agree. To.Marry.Me." He gave the floor a double pounding when he finished. 
"She said no." The trick was to speak from your chest, to make sure your eyes and your mouth were telling the same story. I learned this from Fay, who had never needed a man for security at her place. "Either take what she's offering or leave."

He stayed on the ground for another minute and then lumbered to his feet, wincing as his straightened his legs. I would think of him, months later, when I too would struggle to stand.

"You could have us both," Rose said, gesturing to me. "Same price." In that moment I decided we had enough money. I could work in a laundry again, if we needed money. Rose could teach art. We could grow our own vegetables and make our own clothes if we had to. Anything would be better than pretending the things Rose and I did together were for the pleasure of paying men.

"I wouldn't dream of defiling you," the man said to Rose. His eyes flicked over to me. He seemed genuinely surprised to see me there. "You then."

Sorry, Rose mouthed to me. She tried to reassure me with her eyes. As we climbed the stairs to my room, the piano started up.

Enjoy the Spring of Love and Youth,

To some good angel leave the rest;

For Time will teach thee soon the truth,

There are no birds in last year's nest!

"Leave it on," he said as I went to unbutton my dress.

He untied his shoes silently; his socks were a startling white.

"She's such a beautiful girl," he said as he climbed on top of me. He smelled of corned beef. I tried not to stare at his watering eye but my own eyes kept seeking it out. Had someone scratched it? Maybe he was born that way. I tried to feel sorry for him. I imagined his eye was a 
window into the ocean; behind it lay sand, water, palm trees. The red was the light from the setting sun. "Marian," he said with a strangled cry. I wondered what he would do if he knew Marian was my middle name. He suddenly circled my neck with one of his hands, the calluses on his palms rough against my throat.

“No," I said, but I didn't have a voice anymore.

"Marian." He squeezed my throat in time to the song she was now playing downstairs: Come, my darling, here reclining / Sing those songs I love to hear!

His hand on my neck was hot and heavy, my throat an icy fire. I had heard of men doing this. The other girls still talked about a girl named Emma who was strangled in the house with her own stockings. After her death, Fay shut down the house for a whole week and refused to reopen until the police arrested the man. I could feel my heart pounding wildly. I thought, My heart is pounding wildly and then a blinding darkness came for me. When I finally woke - minutes? hours? I had no way to know - I was alone in the house. Rose was gone. My money too. I found my empty stockings crumpled at the foot of the stairs.

I read about her wedding in the paper that night. May Lead a Better Life: A Wealthy Farmer From Carroll County Weds a Fallen Woman. They said the bride wore her best outfit, a brown velveteen skirt trimmed round the edge with close, vertical rows of braid. After her vows, the bride passed out cold, but once revived, they left on the 8 o'clock train for Carroll County. ${ }^{32}$

${ }^{32}$ Adapted from The Courier Journal - Nov. 14, 1888 


\section{The Courier Journal 33}

\section{Medical}

Life is full of collisions. We are constantly colliding with somebody or something. If it isn't with our neighbors, it is with some dread disease that "knocks us off the track" and perhaps disables us for life. Women especially it seems have to bear the brunt of more collisions and afflictions than mankind. In all cases of nervousness, bearing-down sensations, tenderness, periodical pains, sick head-ache, congestion, inflammation, or ulceration and all "female irregularities" and "weaknesses," Dr. Pierce's Favorite Prescription comes to the rescue of women as no other medicine does. It is the only medicine for women, sold by druggists, under a positive guarantee from the manufacturers, that it will give satisfaction in every case, or money paid for it will be refunded. See guarantee on bottle wrapper.

${ }^{33}$ Adapted from The Courier Journal - May 8, 1889 


\section{A gift for the bride-to-be}

"I was wondering if there is a painless way to insert a hair pin on a girl's wedding day."

I warily eyed the hair pins on Miss MacCorkle's dressing table. God I was tired of these conversations.

"No."

"It's possible that after a long day, he will be too tired to care about my hair," she said hopefully.

"If he's too tired on the wedding night, he won't be the next day. Or the day after that."

"Leo is different than most men," Miss MacCorkle said.

"He's a man, isn't he? Better prepare a song to sing."

"Aloud?"

I gave her a look. "Don't be stupid."

"The only songs I know are church hymns."

"Then make up one."

"I don't have much practice making up songs."

For fuck's sake. Her mouth fell open in surprise, and I realized I had spoken aloud.

“There's a song we would sing at Fay's, to send off a girl when she got married."

Miss Lucy had a baby. She named him Tiny Tim.

She put him in the bathtub

To see if he could swim.

He drank up all the water.

He ate up all the soap.

He tried to eat the bathtub,

But it got stuck in his throat.

Miss Lucy called the doctor

The doctor called the nurse. 
The nurse called the lady

With the alligator purse.

"Mumps" said the doctor.

"Measles" said the nurse.

"Not a damn thing" said the woman

With the alligator purse.

Miss Lucy hit the doctor.

Miss Lucy slapped the nurse.

Miss Lucy paid the woman

With her alligator purse.

Out ran the doctor.

Out ran the nurse.

Out ran the lady

With the alligator purse.

Miss MacCorkle was still laughing when I finished. I sometimes forgot how young she was. "Mrs. Clarke has an alligator purse! She's terribly proud of that silly bag."

"Of course she is," I said, and I had to stop brushing her hair because she was laughing too hard. 


\section{Be it enacted by the General Assembly of the Commonwealth of Kentucky ${ }^{34}$}

That any person or persons who shall be found guilty of inducing, persuading, aiding and enticing any female, who has never been married, under the age of twenty-one years, to enter a house of ill fame, house of prostitution, assignation, or bawdy-house, whereby such female so induced, persuaded, aided, enticed, shall be seduced and lose her chastity and virtue, shall, upon indictment and conviction, be confined in the State penitentiary for a period of not less than two nor more than five years, in the discretion of the jury.

${ }^{34}$ Adapted from The Courier Journal - “Powell's Trial," June 29, 1884 


\section{The moral and spiritual condition of the Home is encouraging}

"I don't understand the parasols girls are carrying these days," Mrs. Kesselman said. "The handles are the size of billiard balls. They practically have to use two hands." She held up her hands up as if clutching an object as large as her head. "Do you have a parasol like that, Regina?"

"I can assure you my parasol has perfectly ordinary handles," said Mrs. Shippen.

“There's such little regard for matching a parasol to one's complexion. I passed a redheaded girl on the street recently. She was carrying a scarlet parasol and the tints transmitted to the poor girl's face. Will this rain never end? One day of sun and now back to rain. The river will flood soon, mark my words.”

"What progress have we made on finding a replacement for Lucy?" Mrs. Shippen asked.

"None. And the wedding is three weeks tomorrow," Mrs. Clarke said. "Still a thousand small details to iron out. Her final dress fitting is this afternoon."

"Did she end up choosing...?"

"Indeed."

"I hope it's more flattering than you feared."

"It isn't," Mrs. Clarke said. "When it comes to her replacement, I wouldn't mind an older girl. I think Lucy has been too free in what she shares with the girls. Greater care should be taken to prevent inmates from knowing what is said at meetings. It wouldn't surprise me to learn that the girls listen to these meetings with their ears pressed to the door."

"I had a thought recently," Mrs. Kesselman said. "About those two girls who left without permission last year. Going forward, we will mark such absences as expulsions."

"Why?” asked Mrs. Shippen. 
"Left without permission makes it sound as if girls are allowed to wander in and out as they please, as if the Home were a fabric store."

"No one of any intelligence would mistake our Home and the good work we do for a fabric store."

"If our records give the impression that we are failing in our duties as the lady managers, then how long before a different group decides they should oversee the day-to-day operations of the Home?"

"You mean, how long before us lady managers are replaced by managers," said Mrs.

Shippen. 'I understand your concern, but I don't believe that recording a lie is the best possible solution."

"We don't always deal in best possible solutions, Regina."

"I thought we also didn't deal in lies."

"What about the Davidson girl as Mistress?” Mrs. Clarke suggested. "She's the right age. And the girls enjoyed that art lecture she gave a few months ago.”

"I heard she has a new beau. But even if she were single, I would not be inclined to offer her the position. I never blamed Eliza for her behavior, but the reverend - well, that's a different matter. Minnie became a very headstrong girl,” said Mrs. Kesselman.

"Woman," said Mrs. Shippen.

"What now?"

"Minnie is close to my age. And I consider myself a woman, not a girl."

"Well," Mrs. Kesselman said. 
"A great many fathers are overly indulgent with their daughters," Mrs. Clarke said. "I'll admit my own father was guilty of it. He used to let me get away with anything but when it came to disciplining my brothers, he had a much firmer hand."

"Mr. Wrocklage wants to give a lecture on 'Money and Morals' to the girls," Mrs. Kesselman said. "He suggested next month."

"We can’t afford to pay lecturers at this time," said Mrs. Shippen. "All money is promised towards the new home."

"He said he would deliver it free of charge."

"The last time I saw Mr. Wrocklage, he informed me of his crusade to ban pernicious literature because of - and this was his exact phrasing - 'the fallen thousands who roam the city in sin that owe their first downward steps to a familiarity with vice through the reading of novels and the daily paper,' which in his opinion, devotes too much time to crime and scandals."

"He sounds like my father," Mrs. Kesselman said. "He used to say I should spend more time reading biographies."

“And did you?" Mrs. Clarke asked.

"Good gracious no. I always found biographies dull. War, war, and more war. But Mr. Wrocklage means no harm.”

"The man is a hysteric. I will not extend him an invitation to deliver a useful lecture on money only for him to change course and subject the poor women to a rant about the dangers of novel reading. If he wants a crusade, I would be happy to point him in the direction of more timely causes."

"To be fair, I do agree with him to some extent - the newspaper prints the most salacious stories. I suspect they do it simply to boost sales," said Mrs. Clarke. 
"We would do well to remember that Mr. Wrocklage is a devout and rather wealthy man, who, with a small push, might be induced to pledge a large sum of money towards the Home," said Mrs. Kesselman.

"Let him pledge money as a subscriber and then we can discuss lectures," said Mrs. Shippen. "But not until I have a check in my hands. Now, other thoughts on a replacement for Lucy?"

"What about Elizabeth Lippy?” said Mrs. Kesselman. "She called off her engagement recently."

“To the Purcell boy?” Mrs. Clarke asked.

"I heard she recently learned about some nocturnal visits he's paid to the place over on Hancock St. Daytime visits too.”

"Is that Lizzie Morgan's?"

“No, Celia Fuller's.”

“And how long before some poor girl from Madame Fuller's shows up here?” asked Mrs. Clarke.

"We should ask Samuel Purcell to be a subscriber then," Mrs. Shippen said. "A repentance subscription if you will."

“Wasn’t your girl Nell at Madame Fuller's?” Mrs. Clarke asked.

"No, she was at Mollie Taylor's," said Mrs. Kesselman. "Or was it Mollie McDonald's? It wasn't Mollie Burns's, I know that.”

'It makes you wonder if there isn't a connection between a girl's name and her character," said Mrs. Clarke. "All these Mollies choosing the same degrading path."

“As you might recall, Ed's first wife was named Molly,” Mrs. Shippen said. 
"She spelled her name M-O-L-L-Y," said Mrs. Kesselman.

"I've been thinking that in the spring and summer, the girls spent their mornings outside working in the garden," said Mrs. Clarke.

"I'm still enjoying the blackberry preserves they made," said Mrs. Kesselman. "Some mornings I'm tempted to eat it straight from the jar."

"But now that it's autumn and the garden is dead, they have too much free time on their hands."

"They seem rather busy, what with preparing their own meals, attending church services twice a week, caring for the children in the Home, and sewing curtains every night," Mrs. Shippen said.

"The garden kept them busy in the morning which established an industrious tone for the day. Who knows what slovenly habits they might embrace without a rigid workload."

“What about baking? We're short several dozen cakes and pies for Saturday's lecture at the church," Mrs. Kesselman said. "They're in desperate need of ginger cakes."

"I have a receipt for ginger cakes - I'll have Annie write it down for you before you leave. It's simply a pint of New Orleans molasses, half a pint of lard, half a pint of buttermilk, two tablespoons of soda, two teaspoons extract of ginger. Heat the milk boiling hot, pour along with the molasses into a bowl with the soda and ginger. Stir in flour until stiff, then work in the lard, knead well, roll out, cut in cakes, and bake."

"Even Nell would be hard-pressed to mess that up," Mrs. Kesselman said.

"What if the women attended science lectures at the Masonic Temple?" said Mrs. Shippen. "Professor Richards has been delivering a wonderful morning lecture series on 
chemistry. Yesterday's was on the wonders of oxygen, and everyone was on the edge of their seats. He had to stay an additional half hour to answer all the questions."

"Lectures will not bring in additional money, which as you reminded us earlier, we desperately need," Mrs. Kesselman said. "Besides, they had that art lecture from Minnie recently."

"That was months ago."

"I was thinking the girls could take in laundry, in addition to the sewing they are currently doing," said Mrs. Clarke. "Speaking of wonders, you wouldn’t believe Belle's efficiency with the laundry. No stain is safe around her."

"She ought to come to my house," said Mrs. Kesselman. "Teach Nell a thing or two. I can't trust her with my better things. Anything nicer than flannel, I send out."

"If you don't grow up with quality clothing..." Mrs. Clarke said.

"They often learn the easiest way to do things, not the best. She tried to take a hot iron to my silk stockings the other day."

"Surely they do these things deliberately," said Mrs. Clarke. "As a jealous sabotage."

“It's not insidious, as far as I can tell. More of a sow's ear, silk purse situation," Mrs. Kesselman said.

"If the girls are to take on more laundry, and Belle will be the one managing the operation, we should buy her a new outfit," said Mrs. Shippen. "To show our appreciation for her hard work."

"I've never met a girl who doesn't enjoy a new dress," Mrs. Kesselman said.

"I've never met a woman who doesn't enjoy feeling appreciated," said Mrs. Shippen. 
"Of course we would need to add the new articles gradually to her wardrobe. To not incite resentfulness in the other girls," Mrs. Kesselman said.

"A heart at peace gives life to the body, but envy rots the bones," Mrs. Clarke said. “Let's adjourn for today," said Mrs. Shippen. 


\section{Bean bags}

"Black-eyed peas was the right decision," Annie said as she handed out the Jumbo bags.

She had embroidered mine with my initials and a rose. "Since you took such an interest in the rose garden last spring," she said. Caroline's had a wedding bell. Mary Ann's was covered with lace, her initials in red.

Waiting for my turn, I imagined my bags easily alighting on the board again and again. A perfect score. But we were all bad - terrible, really - and once we made our peace with that, we had a fantastic time.

Towards the end of the game, Mrs. Goss peered over the fence. "What are you girls up to with all that shrieking?"

"Bean bags," Annie said. Her cheeks were flushed and with the setting sun lighting up her hair, she little resembled the haggard woman the newspaper had described. "Do you want to join us?"

"Doesn’t look like a game for an old lady like me," she said. "How's young Tabitha?"

"She learned how to draw horses recently. She's very talented."

I'd never seen a horse resembling the cross-eyed animal young Tabitha drew but clearly Annie was blind to her daughter's faults.

That night, I laid my Jumbo bag on my stomach and thought that it had been a nice day. Almost a perfect day, the kind of day where the weather matches your mood.

I would leave this house with a baby and a job, and as far as life went, maybe that was the best you could expect. "When you're old enough, I'll teach you how to play," I told the baby.

Mrs. Clarke recently told me she thought I was having a girl, based on how wide my hips were. But who would want to learn these things ahead of time? 


\section{The bride passed out cold: part 2}

"What do you think?" Caroline asked. She twirled and her wedding dress half-heartedly fanned around her. The dress, similar in color and fit to the sacks of flour in the pantry, was a donation from the Trinity Methodist Church women. Her freckled wrists protruded from the too short sleeves. Pert beige diamonds marched across the hem and the collar and a faded cream band tightly gripped her stomach.

"It reminds me of something my grandmother wore at her wedding," Mary Ann said. Her daughter had arrived the night before. Mary Ann said labor was no more painful than a bad toothache. "Honestly I don't know understand the screaming and carrying on some girls do."

Mrs. Clarke said that a baby did not need four names but Mary Ann insisted that her daughter's name be recorded as Pearl Margaret Katherine Sheehan.

"It's the nicest dress I ever owned," Caroline said. "Even if it is difficult to breathe in."

“Take shallow breaths," I suggested.

"And tighten your corset," said Mary Ann. "You can borrow my dragonfly hairpin, the one with the blue stone on it. But for God's sake, don't run off to Florida with it. I'd like to give it to Pearl Margaret when she's old enough to appreciate it."

A flash of lightning lit up the room and thunder followed close behind. All day it had been doing this dance of noise and light, without the release of rain. "I heard it's good luck if it rains on your wedding day," Caroline said anxiously.

Mary Ann opened her mouth to argue but, at a look from me, quickly clamped it shut.

During her wedding, right after Caroline promised to love her husband Fred in sickness and in health, she fainted. She swayed, sank gracefully to her knees, and ended up flat on her back. 
The look on her new husband's face as she was falling. Not again, the look said.

"It's her dress," I whispered as he and I knelt beside her. His hands shook as he awkwardly patted Caroline's hand.

When she opened her eyes, he smiled in relief. "I thought you were dead."

She smiled up at him from her spot on the floor. What a trusting face she had.

"You certainly gave new meaning to the phrase fallen woman," I whispered as I helped her to her feet.

When they left for Jacksonville, I said something akin to a prayer.

Dear God please let him be worthy of her. 


\section{Gifts}

"Since you will be heading up the laundry project, we would like to present you with a new article of clothing." Mrs. Clarke handed me a pale pink handkerchief, the initials BS embroidered on the bottom left. "We don't want to create rivalries with the other girls so best to keep that hidden in your room. There's more where that came from, if your efficiency with the laundry continues."

“Thank you. Although, may I ask what the S stands for?

"For Smith, of course. Isn't that your last name?"

“No ma’am. It’s Queeney."

“Oh.” Her look of surprise made me laugh, and after a moment she laughed too. "I wonder why I thought it was Smith. What a silly woman I am at times."

"It's a very nice gift," I said.

"We appreciate your hard work, Belle."

"Thank you." 


\section{Improper language}

Mary Ann and I sat on one couch, Rachel, Helen, and Christie on the other. Annie paced anxiously in the back of the room. Heading up the new laundry project was no small task. Mrs. Clarke had apparently convinced all of Louisville to bring their dirty laundry to the Home for me to wash. At this point, I surely deserved more than a measly handkerchief. After a day spent in the basement, I was not in the mood for one of Mrs. Clarke's lectures.

“Do you like Pearl Margaret’s dress?” Mary Ann held up her daughter, whose white dress was an explosion of ruffles and lace. Pearl Margaret blinked solemnly at me and then sneezed. "My cousin Effie sent it."

"Pretty," I said.

Mary Ann grimaced and moved away from me. "You stink, Belle."

I thought of telling her it was the smell of honest work, but I was too tired to argue, even with MaryAnn. My corset felt as if it were strangling me with every breath.

Mrs. Clarke gazed out at us. Her face said, I am disappointed in you girls. But there was a brightness to her eyes that also telegraphed that this disappointment, though inevitable, was not unwelcome.

"I have heard a report of improper language in the Home. I'm offering you girls the opportunity to confess."

The only sound was the noise of Annie's boots nervously tapping behind me.

"I don't enjoy these conversations any more than you do," Mrs. Clarke said.

The tapping grew louder.

"I'm a patient woman. I can wait all day." 
I was ready to unleash a stream of foul words, if it meant we could retire to our rooms before dinner, when Rachel suddenly spoke up.

"I was lacing up my boots yesterday and when one of the laces broke, I said damn." I had never heard Rachel speak in a voice louder than a whisper. We all leaned forward to hear her better. 'I said it because I didn't have a spare one handy but it was wrong to say it, and I'm sorry. I didn't think anyone heard me."

"Thank you, Rachel. For your honesty."

Mary Ann went to stand up but sat back down at a look from Mrs. Clarke. "I believe there is more to be uncovered," she said.

Helen crossed and uncrossed her legs. She tucked a braid firmly behind her ear and cleared her throat. "I said dammit yesterday. When I was looking for Patrick's blue sweater." "You said this in front of your child?"

Helen's braids knocked against her back as she shook her head. 'No ma'am. He was in the nursery, and I was in my room."

"Refrain from that language in the future. Anyone else have something they'd like to share?"

"Last week I said a word I would rather not repeat," Christie said. "What happened was, I gave Auggie prunes with her breakfast and I discovered, just as I was leaving for work, that they had disagreed with her digestion. When I was changing her, some--" she cleared her throat "that is, part of what was in her diaper ended up on me and the floor and all over her back, and I had to change my own clothing and clean the floor, which I knew was going to make me late for work. So I said an ugly word as I was cleaning up the you-know-what." 
"I would have cleaned it up for you," Annie said. "Blood and excrement don't bother me all that much.”

"I appreciate your reluctance to speak the word again,” Mrs. Clarke said to Christie. "Although if you would like to work in the medical profession, you will have to learn how to say the proper names for such fluids."

All this talk about blood and excrement was making me queasy. I took a deep breath, slowly released it.

"I don't recall using improper language, Mrs. Clarke, but it's possible I said something vulgar while dreaming," Annie said. "I often have the most startling dreams."

"I'm not concerned about utterances during sleep. And while these admissions are upsetting, they are not the reason I called everyone in here. I recently found a poem in Miss MacCorkle's room, one she claims she didn't write."

Something was happening to my stomach. A rumbling and a grinding.

"I'm much too busy with Pearl Margaret these days to write poetry," Mary Ann said.

"It was more of a limerick," said Mrs. Clarke.

"I don't write those either."

"It started with "Miss Lucy had a baby."

Saliva pooled uncomfortably in my mouth.

"It mentioned a woman with an alligator purse."

I swallowed and shuddered violently. Sweat broke out on my arms.

"Please stand if you acknowledge the rules about foul language and agree to abide by them." Around me the other girls stood.

“Stand up, Belle," Mary Ann hissed. 
I opened my mouth to speak but a rush of hot sickness rose up instead and splattered onto the carpet. 


\section{Not again}

“There's sewage in the basement," Dr. Shippen said. For once his shirt was crisply ironed. "Was she down there today?"

"She was doing laundry all morning," Mrs. Clarke said.

“All week actually," Annie said. "Belle's head of the laundry project."

"It might be yellow fever." Mary Ann stood in the hallway, a blanket wrapped around her

mouth and nose. "Caroline sent us a letter yesterday and I don't think the envelope was properly treated with sulphur at the post office."

Everything had been wrung out of me. What else was there to release? I sat up and dribbled spit into the bowl in my lap. My stomach made a long-drawn out noise, and everyone looked over in alarm.

"And the baby?" Mrs. Clarke asked.

My hands tightly clutched the bowl as I waited for his answer.

“The baby should be fine," Dr. Shippen said. "But really, Mrs. Clarke. This situation with the sewage is untenable."

I collapsed on the bed in relief, my hands atop my stomach, which rolled and roiled. I found the ocean after all, Rose. 


\section{Abundant hair is an ornament, but it is a responsibility as well}

Miss MacCorkle took the glass bottle out of my hands and sniffed its contents, wrinkling her nose in disgust. "It smells worse than the stockyards."

"Best if you don't know the ingredients." I shook a healthy amount of the watered down onion juice onto her scalp. "It's a special hair tonic. The more your eyes burn, the better it's working.”

She squeezed her eyes shut and covered her nose and mouth with a handkerchief.

The smell made my own eyes water, and I blinked back tears.

"I need you to clean Hattie's room today," she said, her voice muffled from the handkerchief. "A new girl is joining us tomorrow. Such a tragic story."

I wondered if Miss MacCorkle would find her own story tragic if presented to her: The poor girl is balding and engaged to a man who once proposed marriage to a prostitute. And you would not believe the way her future mother-in-law belittles her.

"She was at Madame Sewell's too. Maybe you knew her - Agnes?"

I shook my head.

"Does the spot look bigger to you today? When Mrs. Clarke was here yesterday, we had a rather heated exchange, and afterwards, I brushed my hair rather fiercely."

"You shouldn't take out your anger with Mrs. Clarke on your hair."

"We started talking about the article she wrote for the newspaper, and I said to her, 'But if women could vote, prohibition would pass tomorrow, and wouldn't that be a victory? And the amendment to grant licenses to houses of prostitution?"” She snapped her fingers. "Voted down immediately. But she vehemently disagreed, claiming it would cause strife in families, and that a 
person must be always willing to back up a vote at the ballot with a bullet and was I suddenly volunteering for military duty? Then she left in a huff."

"She didn’t like you speaking your mind."

"Leo ignores the advice she gives him. He says I should do the same. Did I tell you he gave me a kitten yesterday? She has the sweetest striped face. I named her Zebra. But after our argument yesterday, Mrs. Clarke said I couldn't keep a kitten in the house, she said cats spread diphtheria."

“That's ridiculous. I had a cat when I was at Fay's, and I've been sick here more times in six months than I was in the four years I was there.”

“I'm never letting Zebra into the basement, I'll tell you that." She lowered her voice. "But I didn't put him outside. I was afraid he would be snatched up by an eagle. Or a hawk. "There aren't hawks in Kentucky this time of year."

"I don't enjoy arguing with Mrs. Clarke. I should have made clear to her yesterday that I don't think all women should be allowed to vote. Those who broke the law, for example. It would be unfair to give those women the same privileges as those who follow the rules. Actions should have consequences."

"Don't they always?"

“Mrs. Clarke said if we can't trust all women to make good choices, no one should vote. But I've never understood the idea behind collective punishment."

"Would you grant someone like me the right to vote?"

"I would have no problem with you voting. Since I know you. But you know how most people are - they probably won't ever be able to look past your mistakes." She removed the 
handkerchief from her nose and mouth. "How long before you can rinse out this foul-smelling stuff?"

There was no need for the onion juice to sit on her hair but I said, "Another half hour at least."

"Maybe I should write an editorial. Like Mrs. Clarke."

"Writing to the newspaper is a waste of time." I thought of all my letters to the paper that had gone unanswered. "Besides, you'll never vote on the issue of suffrage. If men had their way, they'd encourage women like you and Mrs. Clarke to argue with each other about suffrage. That way, they can keep doing what they're doing, which is nothing, while claiming you nattering hens are too divided on the issue."

"If my mother were still alive, she'd probably agree with Mrs. Clarke."

"If my mother were still alive, I would not be brushing your hair every morning."

"I started pulling out my hair after she died." Miss MacCorkle said. "Eyelashes too."

I realized I already knew this. "You wanted to feel something."

"I used to save the hair. Roll into a ball and hide it under my bed. Sometimes I would paste it onto the head of my paper dolls."

I felt an unexpected pang of tenderness for her. For me. Two motherless daughters. "I don't do that anymore," she said. "Save the hair."

I nodded, as if I believed her. 


\section{Agnes}

The new girl whistled at the sight of the Pearline soap boxes. There was an easy familiarity in her words and her body, as if she had lived in the Home for months, instead of hours. She was going to chafe under Mrs. Clarke's rules. "It stinks of shit in here," she said.

"They have sewage problems."

I showed her the washtubs, the irons, the drying racks.

"Two irons," she said. "Fancy."

"The one for collars and cuffs works just fine on dresses as well. No need to heat up both."

"I had your old room at Fay's," Agnes said. "The other girls still called it 'Belle's room."'

"Were the gold curtains still up?"

"And the purple bedspread," she said.

"You weren't there long," I said with a nod at her stomach.

"I had good luck my first month, convincing men to pull out. But then someone complained."

"Fay hates complaints. And complainers."

“I didn't open my own establishment..." Agnes drawled while looking down her nose. I laughed. It was a good impression.

"One of the girls told me to use a lemon peel. And Charlotte gave me some of her Spanish pills but all they did was turn my urine orange. I thought it was blood at first. I blame Fay."

"For your piss turning orange?" 
"No, for the baby, you dummy. She should have had options for us. Ways we could protect ourselves from pregnancy."

"She says that's up to the girl."

"But she's the boss, isn't she? Bosses should look out for their employees."

"I'd like whatever job you had to believe that. Who did Fay give my room to anyway? Charlotte was hoping for it when I left. She always said it was the biggest room. Except Fay's of course."

"The biggest room," Agnes scoffed. "Fay gave it to a new girl. Well, not a new girl. An old girl who came back. Someone named Rose."

Impossible, I thought. And yet.

“This girl was at Fay's last year and then she married a farmer right before Christmas. Some of the girls said she was crazy to leave a rich husband, but I saw the way she was walking. Careful like." Agnes walked around the basement with an exaggerated limp. "I saw my own mother walk that way enough times."

How could Agnes not hear my heart pounding away? I heard it in my ears and felt in in my fingers. Surely even the baby could hear it. My heart is pounding wildly, I thought.

"Do you know her full name? This Rose?" Amazing to hear my voice, how normal it sounded.

"Rose Walker I think."

Rose Marie Walzer, she said her first day at Fay's. But my friends just call me Rose. 


\section{Permission}

Miss MacCorkle shook her head. “Mrs. Clarke wouldn't like it, and I've been trying to stay on her good side. The wedding is less than a week away."

"I won't be gone long. Please." I held my hands in front of my face. It took me a moment to remember this was what the farmer had done while begging Rose to marry him. I quickly put my hands by my side.

"You know how she is about you girls leaving the Home. I can't risk another argument."

“We don't have to tell her I left. It will only be for a few hours, she'll never know. I'm caught up on my chores today."

"But what if she stops by unexpectedly?" She was wavering.

“Tell her I'm resting. Tell her whatever she wants to hear. She never found out about Zebra, did she?"

This was the wrong thing to say. "No," she said. "You agreed to stay here during your confinement and if I let you visit a friend, then I'd have to let all the girls. Rules are rules." She held the hairbrush out to me. "Mrs. Clarke would kill me if she learned I gave you permission to return to Madame Sewell's of all places.”

"But I'm not returning. I need to check on my friend. She was in Carroll County for months and months and now she's back."

“There's nothing of interest in Carroll County," Miss MacCorkle said. "I'm not surprised she returned. But rules are rules." I could tell from her small smile that she liked the feel of those words in her mouth. She waved the hairbrush at me, and I finally took it from her.

Soon after she arrived at Fay's, I found Rose sitting in the backyard. I sat beside her and watched as she sketched the birds splashing about in the fountain. 
"I thought I saw a bower bird," she said.

"I don’t know anything about birds."

She told me that bower birds built nests several feet tall, and they used a stick gripped in their beak as a paintbrush, smearing the juice of berries on the outside of their bowers to decorate them.

"But why do they do this?"

"To attract a mate of course."

She told me that when she was ten, she and her uncle found a bower while on a hike. This particular one was all blue - blue flowers, blue scraps of ribbons, even blue pebbles. They walked around it, studied it from all sides. When they peered inside, they saw two rooms, a wall of sticks separating them. Her uncle asked her why she thought the male bird had constructed two rooms in his bower. She thought a minute and said, It's so the female can be alone, while she decides if she wants to stay. If she wants to leave, she can fly away, and he won't be able to stop her.

"Is that really why they do that?" I asked. I couldn't imagine such a thing.

She shrugged. “There's no way to know for sure. We can't exactly ask the bird what he was up to now, can we?" She showed me the picture she had drawn. "What do you think? Is it a good likeness?" Her eyes were so light, compared to her dark hair. I spent a long time studying the picture that day, to avoid looking at her too directly.

“It's beautiful," I said when I finally looked up from her drawing.

You can love someone long before you touch them, before you know if they love you back. It's innocent, selfless really, to love someone this way. How differently the world looks when you allow yourself this sort of love. 
I laid a hand protectively over my stomach before turning to Miss MacCorkle. "You should have played with that doll. Your mother would have forgiven you."

Once on the sidewalk outside the Home, I realized I still had her hairbrush clutched tightly in my hand. I reared back and tossed it into Mrs. Goss's yard.

Ten points. 


\section{To live and move in two worlds}

"You're having a boy for sure," Fay said. "I'm good at predicting these things." She shook her head in amazement. "You got fat, didn't you. Use the back stairs so you don't scare off customers."

Rose was sitting in bed, staring at a book in her lap. Tears immediately welled up in my eyes. I held onto the doorframe for support since my legs were suddenly shaking uncontrollably. "You're very thin," I said.

"Not you," she said.

God but her smile hadn't changed a bit.

I lowered myself onto the bed beside her. "Are you hurt?"

"It doesn't matter now." She placed her hand on my stomach, and I placed my hand on top of hers.

"It matters to me," I said.

"I took care of it," she said.

"What does that mean?" But I knew.

"He told me he killed you. He said I'd be next if I didn't marry him." She looked down at her hand on my stomach. "What does it feel like, having a baby in there?"

"Like finding a bower bird and a yellow-rumped warbler and a ruby-crowned kinglet all on the same day."

"If she's a girl, we'll name her Ruby," Rose said.

“And if he's a boy, Kinglet," I said.

"God help us," she said. "Two women raising a boy. A boy named Kinglet, no less." "We'll figure it out," I said. 
"This I believe." She handed me the book in her lap. It was the Bible. "I brought you a present."

"I've read from that book nearly every day since you left. Did you know Mary Magdalen is mentioned fourteen times?"

"You haven't read this version," she said. "Go on, open it up."

A stack of bills fluttered onto the bed until we were sitting in an ocean of green, a green even purer than her eyes.

"He was a wealthy man after all, Belle." 


\section{The Courier Journal ${ }^{35}$}

\section{Monkey Skin Muffs: A New Fashion That Probably Will Not Last}

Monkey skins are going to be popular this winter for muff and cloak trimmings. As far as the limited supply will permit, they will displace furs in the favor of women who wish to be fashionably attired. Monkey skins have long been popular in Paris and Berlin. Last winter a consignment of 5,000 skins were received in this city and almost instantly disposed of. The best skins are about thirteen by twenty inches and are covered with large, glossy hair. They are worth about \$3 each at wholesale. Smaller skins and dyed skins are much cheaper. More than half the skins that come to market are useless for the purpose of the wrap makers. They are laid aside, and go eventually to the leather workers, who make them into purses and satchels. A misfortune for the trade is that goods made of monkey skins will long outlast the probable duration of the rage for them. A dealer said yesterday that the woman who buys a monkey skin muff this winter ought to have it in good condition ten years hence.

${ }^{35}$ Adapted from The Courier Journal - October 19, 1888 
A HOME FOR FRIENDLESS WOMEN - PART III 
The Courier Journal - September 26, 1901

The Home for Friendless Women will celebrate its silver anniversary today, and the Board of Managers will keep open house from 4 till 9 p.m. They will gladly welcome all friends of the home, both old and new. Some cards have been sent out but all may not have been reached, so we extend an invitation through the press. The cards contain a modest request for a quarter. 


\section{Mother remember}

Two presidents shot in her lifetime, first Lincoln and now McKinley dead at the hands of a madman, the most recent one an anarchist. She'd been seven when Lincoln died on Good Friday and she remembered her father's sermon that Easter. She'd tried to focus on his words, while all around her adults wept openly and unselfconsciously, but instead she was overly conscious of her blue and white checked dress, how itchy and hot it was against her skin. Weeks after Lincoln's death, black fabric waved from outside churches and homes. Even saloons were shrouded in mourning.

Poor Mrs. Lincoln, her mother said. First two sons and now her husband. It was one of the few times Minnie recalled seeing her mother cry. Later people would say Mrs. Lincoln's refusal to attend her husband's funeral was improper. Was there a proper way to grieve? Apparently yes.

Thirty-six years later it was Minnie who cried after reading that President McKinley's last words had been, "It is God's way. His will be done, not ours." Surely her own father would say something similar on his deathbed. Such a shocking way to die, shot by a stranger. An intimate death rendered impersonal. The country offered up thoughts and prayers, and then, as before, collective grieving gave way to business as usual; a dead president did not halt the days of the living. And now, another day of meetings and the silver anniversary party in two days and the boys' birthday dinner tonight, and Minnie promised them her famous chocolate cake because, as she told her husband Roland, you only turn six once.

“Chocolate cake! Chocolate cake!” Mark chanted at breakfast and Lucas joined in a minute later, a pattern she imagined her sons would repeat their whole lives. The boys ate their toast and drank their juice, a miracle no one spilled it today, it truly was cause for celebration, 
and they were off to school. Her sturdy tow-headed boys, full of newly acquired opinions and bluster. Their light hair, so unlike her own, served as a daily reminder they were hers, and not hers. This didn't make her sad. Twins at thirty-seven had made her more practical than sentimental.

“Why don’t I pick up a chocolate cake at the bakery run by your ladies?” Your ladies was Roland's term for the women who left the Home. She found it endearing since the Board president Mrs. Kesselman always used the less appealing former inmates.

"I don't mind making them a cake. It's nice to prepare food they enjoy as opposed to always nagging them to eat food they don't."

"Don't forget the paintings from the art gallery are arriving today."

She stared at him blankly.

"The Caperton house," he prompted.

She'd forgotten. "There's the luncheon after the lecture. No matter," she said when she saw his face. "I'll be there. I'll find the time."

“There's a serious problem with the place cards for the luncheon," Pamela said when Minnie arrived at the club. "Margaret's fault, I'm sorry to say. She was so focused on planning her wedding last month it's clear she neglected her other duties. Abby Remond's reads Mother Remember, instead of Another Rembrandt. Margaret's claiming that's what I told her to write but why-would-I-have-said-such-a-stupid-thing?"

Pamela, head of the Art Committee despite her total lack of interest in art, pregnant for the fifth time and decidedly unhappy about it, although to be fair, Pamela was usually unhappy 
about a rotating cast of things. These days the main culprits were the weight gain from baby number five and anarchists. Minnie suspected the place card mistake was down to Pamela, not Margaret, though she knew better than to say that aloud. How ghastly to be pregnant for the fifth time, four children under the age of six at home already. She too would volunteer to head a committee she didn't care one whit about it, if it kept her away from home for a few hours. As Minnie dimly recalled, pregnancy muddled the mind. She'd been a complete scatterbrain while pregnant with the boys: dumping salt in her tea, unable to focus on reading, sewing, correspondence. During those interminable nine months, her only successful endeavors were eating and sleeping.

Minnie took the offending card from Pamela and promised to fix it herself, since descriptive initials place cards had been her brilliant idea, the idea being to take a trait of the guest and create an amusing phrase based off their initials. Pamela Andrews became "Presentation Academy," her alma mater, and Margaret Belknap, she of the allegedly poor transcribing, was "Matrimonial Bliss," a nod to her recent wedding, and the artist Abby Remond was (supposed) to be “Another Rembrandt.” Minnie and Pamela had spent a week thinking up the phrases, and they'd had to assure Mrs. Baker, the oldest club member, that it was perfectly acceptable to use initials corresponding to the women's given Christian names, instead of their husband's.

“Besides," Minnie told Roland, "I can't think of anything clever for Mrs. Roland Morton.”

"Romantic Mother?” he suggested. "Rollicking Matron?"

"Exactly," she said. 
"And," Pamela said, a smooth transition from Margaret-specific anger to a more diffuse one, "The lecture starts in thirty minutes and there's no sign of this Abby Remond. Likely she'll be a no-show like Irene Snodgrass."

"Irene was only a no-show because a carriage ran over her foot."

"It reflected very poorly on us."

"She'll be here," Minnie said. "You know these artsy types."

"She might be an anarchist."

"Don't be ridiculous, Pammy." Although, who could be sure of these things anymore?

Just this morning she read about a woman anarchist shot in the street, middle of the day, by her former lover. She wasn't expected to recover and now the whole world knew her as a woman who penned anarchist literature and - god rest her soul - erotic poems. She hoped Pamela hadn't seen that article.

Even though her artistic life was mostly confined to lessons at the Home these days, Minnie still secretly thought of herself as an artsy type. She'd even sold a few paintings, mostly to friends and family but still. She'd been good but not great, although wasn't that true of any artist? You had to practice to achieve greatness, you had to make time. A modicum of support didn't hurt either. She told Roland that someday, when she has all the time in the world for such an undertaking, she will write a book called Things You Shouldn't Say to Women Artists.

Chapter 1: Why don't you focus on embroidery instead?

When she and Roland first met, she shyly showed him dozens of her paintings, and he quizzed her about color choices and brushstrokes and where did her inspiration come from, and if he wasn't genuinely curious, he did an admirable job faking it. She was lucky; most men were not like Roland. Her friend Marie's husband Felix, for example. Minnie and Marie met in Paris 
while copying sketches at the Louvre for the Director-General of the French museums, a rather dreary job that sounded glamorous to everyone back in Kentucky. Marie's husband was an artist and had grave, immutable opinions: real art was created in a studio, never outdoors; real art favored line over color, etc. Once in a pique, he tossed a painting out the second story window of their home after learning she painted it outdoors. Such a shame because no one could capture the transformation of white clothing in sunlight quite like Marie. In her hands, a woman's white dress in the sun became golden and blue and pink. White is never just white, Marie liked to say.

Back in Kentucky, Minnie sent Marie several letters, but no answer. Easy to imagine they too had been tossed out a window.

Chapter 2: Your desire to be taken seriously as an artist is incurable vanity

Minnie found herself thinking about the copy she made of Rembrandt's Bathsheba at her Bath that summer. Where was it now? Doubtful the Director General kept it. All summer she struggled to capture Bathsheba's stunned, slightly dreamy expression. A servant woman carefully washed her feet while Bathsheba held a letter from the king. If a bubble were to appear above her head, it would read What could the king possibly want with me? Ridiculous because of course a woman Bathsheba's age knew exactly why a powerful man summoned another man's wife to his castle. How to capture the before of her life - before her husband was killed, before she was raped by the king, before she became queen - so familiar was everyone with the calamity that followed.

"You made her look bilious," the Director-General complained when Minnie finally presented her reproduction.

My work here is being applauded and encouraged, she wrote to her parents.

"I suspect she was bilious," Roland said when he heard this story. Loyal Roland. 
Only after the offending place card was replaced (I didn't think Mother Remember made sense, Margaret said tearfully, but you know how Pamela gets if you disagree with her these days), and Pamela seated at a table far from Margaret did Minnie break the news that she had to forego the luncheon. "The Caperton house is Roland's biggest project," she said when Pamela started to object, and even Pamela couldn't quarrel with that.

The Caperton house had become her biggest project as well. Samuel Caperton had made a not small fortune in the leather tanning business and recently hired Roland to build a house for his family over on Third Street, which he kept referring to as "Millionaire's Row." I haven't heard anyone else call it that, Roland grumbled to Minnie.

The Capertons wanted "elegant simplicity inside" (Minnie's job), and "impressive ornamentation outside" (Roland's job.)

In other words, they want their new money to look old, Roland said. As someone who gave away his inheritance at age thirty-five, Roland didn't think much of people with money, old or new. Roland's family had been appalled at his decision to donate the bulk of his inheritance. His father decried his selfishness, his mother begged him to think of his future heirs, and his sister Sarah threatened to never speak to him again.

As the newly elected treasurer for the Home for Friendless Women, Minnie was sent to collect the check from Roland. She presumed the anonymous donor would be older. A balding and unappealing man who expected an appreciative audience to his generosity, and who had no qualms addressing his comments to her breasts rather than her face. Instead, she got Roland, who had a nice full head of sandy hair and whose brown eyes did not stray from hers as he explained it was his grandfather's fortune, and that giving it away brought only relief, with a tinge of guilt. 
Not at the thought of his sons, of which, he was quick to add, he had none. But it didn't strike him as inordinately generous to donate another man's money. She told him that most men who donated to the Home did so out of a sense of guilt as well, but their guilt had very different origins. She thought about him as she walked home that day, his check clutched tightly in her hands. She'd never seen such expressive and attentive eyes on a man. Beautiful eyes really. Not that she would ever say that to him. Roland wasn't like most men, but he was still a man after all.

Minnie skimmed through the program while they waited for Abby Remond. As secretary of the Women's Club, it was Minnie's job to book speakers. She tended to book artists and writers, a bias on her part, she supposed. The lectures were usually well-received, although Mrs. Baker and the other war widows still complained about the Enid Yandell lecture from years ago. When she asked her to give a talk, Minnie didn't know the woman was one of those lunatic Lost Cause supporters. She presumed Miss Yandell would discuss her contribution to the Woman's Building at the World's Columbian Exposition and instead, she chose to rehash the very public rejection of her proposed Confederate monument. Much like anarchists, Lost Causers were everywhere for a spell. Minnie once came across a group decorating Confederate graves at a nearby cemetery, weeping and carrying on while a choir belted out "America." Laughable really, although that day Minnie had been alarmed at the size of the crowd. They seemed to blanket the entire cemetery; all that pageantry and pomp for the losing side? People were peculiar, as Roland liked to say. My husband lost his life in the war, Mrs. Baker said frostily during the Yandell Q\&A. Fighting on the winning side. Frankly I wish all monuments meant to commemorate traitors were rejected. Minnie had discovered that no one could derail a lecture quite like an angry widow. 
Abby Remond, in contrast, seemed safe enough. A graduate of the Fine Arts School of Boston and later the Pratt Institute, where she taught drawing for three years until her marriage to the architect Mr. Dwight Remond. Since then her focus had been the architectural side of design (e tu, Abby?) and creating Mother Goose prints for school rooms and nurseries.

Wouldn't it be lovely to sit outside at a café, similar to the ones she remembered from Paris, and talk with a fellow artist? She could ask Abby Remond what she liked to paint before she married and suddenly had to dedicate her time and talent to her husband. Or maybe they could talk about Rosa Bonheur, whose death had made Minnie cry even more than McKinley's. Miss Bonheur, with her pants and cigarettes and enormous paintings of animals. Now she was an artist.

Five minutes before the lecture was to begin, Abby arrived. "So sorry," she said. "I got lost on the way here." She was younger than Minnie expected, easily a decade her junior. Petite with enormous blue eyes, the word "dainty" clung to her (Child-like, isn't she? Pamela whispered to Minnie, still miffed at her tardiness). Windblown hair, pink cheeks from her bicycle ride. The lack of corset was noticeable. More and more Minnie found herself baffled by the fashion of younger women. After twins, a corset was a necessary evil. But oh to be twenty years younger, zooming here and there on a bicycle. What freedom of the body. How different the world must appear from up high, she would feel she owned the whole city. Last summer her friend Ruthie's son Edward tried to teach both Minnie and his mother how to ride a bicycle. Unsuccessful, unfortunately. Minnie could never shake the feeling she was one fall away from a broken bone. 
Minnie led the young woman to the stage. "It's my pleasure to introduce Mrs. Abby Remond, whose lecture today 'The Art of the Ordinary' should be of great interest, even to those of you who claim to not have an artistic bone in your body."

"She's talking about me," Mrs. Baker stage whispered.

“Now don’t sell yourself short, Mrs. Baker," Minnie said. "In fact we have Mrs. Baker to thank for the floral decorations on the table -" she paused for the club women to clap enthusiastically. "And after the lecture, Mrs. Remond's Mother Goose prints will be for sale. It's never too early to be thinking about Christmas presents. Let's offer a warm club welcome to Mrs. Abby Remond."

“Thank you, Mrs. Morton,” Abby said. "I'm here today to dispel the myth that art is only created in a studio. For me, art is everywhere. In the blades of grass, the way the sun colors the sky magenta on a warm summer night, the soap bubbles dancing across a dinner plate..."

Minnie was reminded of all the sermons she listened to as a child, except her father had been waxing about God, not art. Last spring he retired from the church after her mother fell ill. It happened slowly enough: a forgotten word here, a passing bout of confusion, and then one day she got lost walking home from the church, a path she had trod for nearly thirty years. Senile dementia, the doctor said. Over the past few years, Minnie had watched her mother fade into someone much gentler and kinder than the woman she had always been. Sometimes Minnie felt guilty that her mother's mental decline signaled a calmer phase of their relationship.

Over the summer a divorced Slavic woman named Svetlana moved in to help out with her mother, and much to Minnie's surprise, her mother did not mind having another woman in her house. Despite the substantial age difference, she thought she and Svetlana were childhood friends. Minnie's mother happily ate the dumplings Svetlana prepared and she even allowed this 
divorced woman to help dress her. This from the person who once claimed Slavic women were hard-hearted, that dumplings were food for the poverty-stricken, and that a divorced woman was no better than a hired girl let go without references. Yes, people were certainly peculiar.

"A colorful parasol on an overcast day, a basket of ripe strawberries, a woman absorbed in her ironing..." Minnie suspected that Abby started cataloguing the art of the ordinary after she traded her art career for a husband, when even a simple walk through the park likely filled her with longing. Minnie had experienced something similar after her own marriage, although what had caught her eye and occupied her thoughts had not been art but babies.

Babies - on every street corner

Babies - in every shop

Babies - sleeping, wailing, babbling away in their carriages.

For years Minnie was ambivalent about children. Her friends with children weren't a walking advertisement for health or happiness, to be honest. But after she and Roland married, she suddenly saw the distinction between having a child and having his child. Yet, the months ticked by and she remained stubbornly, decidedly, not pregnant.

Her mother: You used to say you didn't want children. I'm not saying it's your fault for waiting until you're nearly forty. But.

Her father: Poor Minnie.

Roland's mother: Poor Roland.

Roland: We've been trying for a year now. Maybe it's time we discuss adoption.

During one particularly tearful supper she told Roland she counted fifteen baby carriages that day and Roland's suggestion that she walk by the riverfront, where she was unlikely to encounter a parade of baby carriages, only made her cry harder. But she heeded his advice, and a 
few months later she was pregnant with the boys. (Roland had been right that she was unlikely to come upon a carriage on such a walk - she discovered no one else was foolish enough to walk by the riverfront and brave the smell of the nearby stockyards.)

Abby held up one of her Mother Goose prints, this one featuring two pigs - This pig went to market, that pig stayed home, this pig had roast meat, that pig had none, this pig went to the barn door, and cried "wee wee" for more - and the women clapped again. One of the pigs wore a striped bib, a knife and fork clutched in his small hooves.

“She's very pretty,” Mrs. Baker whispered approvingly to Minnie. "A great improvement over that Yandell shrew."

“Yes, she’s very talented," Minnie whispered back. An art teacher in Paris once declared, Everyone has talent at twenty-five. Minnie saw now he'd been lamenting his own impending middle-age, his studio full of fresh-faced artists, eager to learn at his knee so they could surpass him. Youth wasted on the young and all that.

Progress, not perfection, one of the suffragists said. Lucy Stone, probably. But what if neither progress not perfection occurred in your lifetime? What if the girls that followed you were confident enough to ride bicycles and leave their corsets at home and yet somehow they too couldn't escape the downward pull of their sex, abandoning promising careers in order to advance their husband's? The lucky ones found time to make art to hang on the walls of nurseries before they were expected to fill up the nursery in their own home. After all the lectures and the club meetings and the marches she'd attended over the years, somehow all that had changed was fashion. Minnie was suddenly grateful for the Caperton appointment, no time to talk art and life with Abby. The girl was so young she'd probably never even heard of Rosa Bonheur. A deeply depressing thought. 
Chapter 3: You don't need art to be happy - simply pretend your iron is a paintbrush Before she left, Minnie bought the pig print. It was more than she would normally spend on a print for the boys' room, but it was good to support a fellow artist and she shouldn't be so hard on Abby. What did she expect from these young women? Everything and nothing. She could have told Roland that day that most of life's decisions were born out of a sense of guilt. You did too much or you did too little. Wee wee you cried, all the way home.

"Very thought-provoking, thank you so much." Minnie gave Abby’s arm a motherly squeeze on her way out. Such thin arms on the girl.

Well, life would toughen her up soon enough. 


\section{The Courier Journal ${ }^{36}$}

\section{Woman Bachelors: Clara Barton, Frances Willard, Rosa Bonheur, and Florence Nightingale are a few of them}

It is a little curious to note that so many of our heroines have never cared to write the title "Mrs." before their names. Rosa Bonheur, over seventy, is one of these women bachelors. It is said she had fewer offers of marriage than the others. Miss Bonheur has too much of the masculine element about her to encourage suitors and her extreme matter-of-factness makes it difficult to approach her sentimentally. Very many artists have fallen in love with Rosa Bonheur from her work. Crowned heads have bent before her, and, more than once, princes of the blood, becoming acquainted with her, have told her of their very great adoration for herself and her genius. But this strange woman persists in neutralizing her personality before that of the animals she portrays and points to them saying: "Could anyone do less with these for models?" If you ask a notable woman why she has not married, she will respond flippantly. Press her closer and she will show embarrassment. And then you get the truth, which is that women of great intellect invariably love men of small brains, men whom they pity at first and then eventually marry. When a woman remains single, it is because she is ashamed to ally herself with such men, men who cannot support themselves and who could never mold the opinion of the world.

${ }^{36}$ Adapted from The Courier Journal - Sept. 2, 1894 


\section{Millionaire's row}

Halfway down the block and she already regretted her impulsive purchase. The twins delighted in playing soldier, transforming tree branches into rifles; they had no interest in nursery rhymes and pigs in bibs. Terrifying really, their newfound interest in war games, their constant staging of death - I killed you! Now you're dead! She couldn't help but worry they were acting out their future fates. Roland said she might as well complain about snow in the winter. He believed that peace occasionally had to be purchased by war and wouldn't she rather have a son with the moral courage to fight for what he believed was right and true?

Of course not. She would rather a living coward for a son, than a dead brave one. And she knew she wasn't the first mother to say so.

At least it was a pleasant day for a walk. Autumn and spring days in Kentucky always made her forget the oppressive dampness of summer and the sting of winter. There was a time it had been revolutionary to walk alone as a woman and now it wasn't. What was revolutionary today? Riding a bicycle without a corset, for one. At age twenty, she and her friend Ruthie travelled by train to hear Lucy Stone give a speech. Her mother was furious when she learned about the trip. She thought women like Mrs. Stone wanted to destroy the fabric of society with their demands for suffrage. In contrast, her father was more hurt than angry: You don't trust me to vote on your behalf, he said sadly.

So much time she wasted as a young person, quarreling with her parents. She regretted

that now. But she didn't regret hearing that speech. All these years later, she could still quote the ending of it, and the words would come to her unexpectedly: while giving the boys a bath, preparing a meal for an elderly neighbor, walking to a meeting. Women are part of the eternal 
order. And we will continue to speak the truth fearlessly and in time we will turn the scale to the side of equal and full justice in all things.

By the time Lucy Stone finished speaking, the women in the audience were crying and cheering, arms linked as they chanted "Full justice in all things!" Back on the train, she saw on Ruthie's face the same feverish excitement she knew was stamped on her own, and as they travelled back to Louisville, she gazed out the window and everything - the farmhouses and the fields, even the cows calmly eating - moved her to tears. How beautiful and expansive the world was. Full justice in all things. The power and weight of those five words! How different her life would be from her mother's, all the doors closed to Mrs. Eliza Davidson would swing open wide for Miss Minnie Davidson. Come on in, walk on through, we've been waiting for you.

Well, she was very young then.

Now she and Ruthie were married mothers, Lucy Stone was dead, and at the end of a long day, when Minnie caught sight of herself in the mirror, it was her mother's eyes peering back at her. No, worse than that - it was her mother's neck there in the mirror. When you consider the alternative, growing old is not so bad, her father liked to say. But it was easier to age as a man, that much was clear. Less concern about fashion. Don't wear that, don't sit like that, don't say that. Don't don't don't. Respectability learned by its murky counterpart. What relief she'd felt when the doctor announced she'd delivered boys.

She cut through Central Park and made her way to Third Street. Assuming the Caperton job was a success, Roland's firm would be asked to build more houses on this block and Roland would finally prove to his family he didn't need their money to succeed. His family had mostly forgiven him, and Sarah's threat to never speak to him dissipated soon after he built her a home on this very block. Millionaire's Row indeed. 
She found Roland in the Caperton's dining room, surveying a row of landscape paintings lined up against the wall. All around were the sounds of a house coming together. Hammering, sawing, muffled voices. Two men walked past carrying planks of fresh-smelling pine, one of them whistling a tune she didn't recognize. From upstairs she heard a crash followed by a loud curse.

"The problem is, these all look the same to me." Roland's voice echoed in the mostly bare room.

She laughed. "But they're of different scenes. They can't possibly look the same to you." "They all feature water. Luckily I have your artistic talent to guide me."

She pointed at the middle painting, horses grazing by a fast-moving river. "That one will match the rug." She said this even though she preferred the painting on the left, of the haystacks. Years ago she'd painted something similar, although hers had been less about the haystacks and more about how the rising sun colored the haystacks. This painting, in contrast, was strictly about the haystacks. A haystack is never just a haystack, she imagined Marie saying.

"What a pity," said Roland. "I prefer the haystacks. It reminds me of that painting at your parents' house, in the front room."

"Mother hates that one. She only displayed it because Father insisted."

Chapter 4: You used to paint the most realistic landscapes

"No surprise there." He nodded at the parcel in her hands. "Did you bring me something?"

"For the nursery at the Home. The lady lecturer was selling them, and I took pity on her." She showed him the print. "The Capertons would never agree to hang this in their nursery." 
"Not unless you told them it was priceless," Roland agreed. "I do like that pig in the bib though."

Minnie thought, not for the first time, how much she disliked the Caperton house. How cold and unwelcoming it was. Everything from the walnut paneling in the dining room to the limestone out front was designed to eclipse their neighbors, to highlight their very important status. No amount of haystack paintings or brightly colored rugs could hide that this wasn't a home at all, merely a vessel for expensive things. It struck her as an exhausting way to live, always needing more, and better, than someone else.

A gentle breeze blew in through the open windows behind them and goosebumps suddenly appeared on her arms.

“Someone's walking across your grave," Roland said. 


\section{The Courier Journal ${ }^{37}$}

\section{Too Much Art}

We are suffering from too much art at present. The number of so-called artists and art students is simply overpowering. All the schools of art are crowded to their doors, and every man, woman and child who can draw a straight line or a curve wants to paint and have their own studio. They like to be called artists and though they may never sell a picture outside of their family, they are suffused with joy to hear themselves spoken of as "So and So, the artist." This amateur talent seems to be rampant among the young women. They are all dabbling in oils, and worse, setting themselves up as art critics. You should meet them in a picture gallery, airing their ideas about art! I have the greatest pity for many of them as they struggle to earn their bread, trudging along with their canvas under their arms. But when a girl shows a genius for decorative work, she is likely to make a good living. What pays women the best is needlework. Look at Mrs. Wheeler with her embroideries. She has revived the lost art of embroidery and paints pictures with her needle. She gets fabulous prices, but she does marvelous work.

${ }^{37}$ Adapted from The Courier Journal - Dec. 23, 1883 


\section{The dream}

In the dream, the girl walks towards Minnie. She wants to ask her something. Or tell her something. Whatever it is, Minnie doesn't want to hear it. But the girl is determined. She has quick, careful steps and her hair is blonde and wavy. I can't help you, go away, Minnie tries to say but her mouth isn't working. Same with her legs. And then the girl is in front of her, opening her mouth to ask her question. Wider and wider her mouth opens, and the inside is red, much too red, the wrong kind of red, and Minnie's own mouth fills with hot liquid. She is drowning in her own body. Minnie hears a tearing, like fabric being ripped, except it's her own stomach suddenly gripped open and it becomes a gaping mouth, it becomes Christ's wounds. Once a stomach is open like this, it will never close again.

She's only had this dream twice in her life. The girl doesn't dream anymore, but if she were still alive, she would not dream about Minnie. 


\section{Women's work}

When Minnie first joined the Board, Elsa Mae gave her a tour of the Home. Minnie couldn't help but think of it as the new Home, even though the women had lived in the house on Kentucky Street for nearly twelve years. The solemn gray brick and narrow windows of the old place has been replaced by cheerful red-brick and large east-facing windows. The new Home boasted a green door, instead of the blood-red one Minnie remembered. Even the scowling gargoyle that once fiercely guarded the street was gone.

During the tour, Minnie tried to focus on how different the Home was from its predecessor: the larger bedrooms, the chapel (Named after your dear father! Elsa Mae exclaimed), the in-house infirmary, the nursery, the spacious laundry room with stone floors, each room more light-filled than the next. Still, Minnie couldn't shake the feeling that there was something off, that something of the old home had managed to sneak in. Later, when she was back home, she realized it was the smell. Underneath the vinegar and Borax, the sparkling floors and windows, lurked the deeper tang of old milk and sweat. The animalistic scent of motherhood an unwelcome reminder of what pregnancy did to a woman, how unnatural this very natural thing was when your own body transformed day by day.

After that first tour, Minnie gratefully sank into a chair in the parlor, only to look up and see a portrait of her mother hanging above the fireplace. As she and Elsa Mae discussed her responsibilities as Board treasurer, her mother's portrait, the one she personally painted years ago and which previously graced the walls of the old sitting room, looked down on them. Disapprovingly, Minnie imagined. When Elsa Mae disappeared into the kitchen for tea, she went and stood before the painting. The eyes were all wrong, she saw now, much too wide and innocent for someone her mother's age. She'd never been very great at mouths, either; her 
mother's lips were unnaturally fleshy. But she had managed to capture something of her mother, she could see it best in the slight tilt of her head, how her mother always seemed to be about to ask for a point of clarification.

She was very pretty, your mother, Elsa Mae said, when she caught Minnie staring at the portrait.

She was. Minnie hoped she didn't sound too surprised.

That night, safe in her own bed, Minnie dreamed of the girl again, the first time in a decade. She and her mother never spoke about what happened at the old Home. Minnie never even told Roland about that night. What was there to say, how could she explain what it was to watch a woman slice herself open? You could say, There was so much blood. But words failed to capture how it gently gushed from the girl, how it seemed to touch everything in the room. A red Minnie had never encountered with her paints, a swollen darkness, the inside laid bare on the outside.

Walking up to the house now, Minnie was nearly run over by Nancy and Ella, who were carrying a rolled-up carpet out the front hallway.

“Are you here for an art lesson?" Ella asked hopefully when she spied the package in Minnie's hands. "I've been working on my sketches of the basic forms, and spheres are giving me fits. I've grown to hate lemons and apples."

Minnie laughed. 'Keep at it! Next week we'll experiment with shading and light and before you know it, you'll be churning out still-lifes at a dizzying rate. Here, let me." She helped them unroll the rug over the front porch railing. 
"Be sure to beat both sides, ladies," Elsa Mae called from the doorway.

"It's always struck me as rather silly to clean before a big party," Minnie said. "You have to do it all over again after everyone leaves." She lowered her voice. "But don't tell Elsa Mae I said that."

She saw the girls exchange a conspiratorial look, Ella mouthing Elsa Mae as if it were a funny, even scandalous, word.

They think I'm ridiculous, Minnie thought, and she was strangely comforted by the notion. She too would find herself a little ridiculous, if she were an inmate here.

Inside was a swirl of activity: Victoria was cleaning the woodwork in the hallways; Daisy was using a whisk broom to carefully dust the back of a mirror, Birdie was rubbing a white mixture onto the front of the glass cabinets, and flitting about amongst the chaos was Elsa Mae. The matron of the Home was a foot shorter than Minnie and substantially wider, but she moved with the quickness of a much younger, slimmer woman. Minnie had never met anyone as organized and efficient as Elsa Mae, almost like the woman had been patiently waiting her whole life to step into her current position. Maybe she had, since the week after her husband died of consumption, she arrived at the Home with the newspaper in hand and announced they could stop their search because she was willing to do the job for less than the offered salary. She said that living in a house full of pregnant women and crying babies sounded marvelous after spending the last year caring for a sick husband. Within days, Elsa Mae could rattle off the name and hometown of every girl in the home, along with their birthdays, favorite foods, allergies. She kept detailed lists: where the girls took jobs, how long they stayed in the Home, marriages, funerals, etc. If it happened on Elsa Mae's watch, it was dutifully recorded. 
Elsa Mae waved her over. "Mrs. Morton, as you might recall, I'm in the process of reorganizing the contents of the library." She was always re-organizing something.

"And the record books from the first part of the Home's history are missing. Now it's possible the first Matron of the Home did not keep records. An irresponsible and careless thing to do, but I'm not here to judge."

Minnie made a noise of assent.

"I'm not discounting the possibility it was lost during the move. At the risk of sounding critical, it's clear the move was rather haphazard and chaotic. Just yesterday I found a box in the corner of the basement which was full of bean bags. You'll never guess how the box was labelled."

"Dried beans?"

"Wedding present. For all we know, the missing record books could be hiding in a box labelled baby quilts. But what gives me hope is that I found a box of record books that pre-date the move. All I'm missing are the first two years, 1877 and 1878. Might your father might know where the books are?"

"It's possible. He was involved with the Home while Mother was president. But the chances of her remembering are next to impossible. She mostly remembers her childhood at this point."

"Such an unfortunate disease." She gave Minnie's arm a motherly pat that Minnie found touching since she and Elsa Mae were the same age. "Mrs. Kesselman thinks they're lost for good, but I'm holding out hope they are simply misplaced. Oh, and please tell Mark and Lucas happy sixth birthday from me." 
"I will." What a memory on this woman. "Before I forget, I thought this might be a nice addition to the nursery." Minnie handed her the pig print.

Elsa Mae unwrapped it and laughed in delight. Her laugh sounded the way it was written in books: ha ha ha. "Look at that pig with the bib. Thank you so much. I know just the spot for it. Mrs. Williams and Mrs. Kesselman are waiting for you in the kitchen." She lowered her voice. "Mrs. Williams brought cookies."

"It's more than the frowsy hair and slovenly dress," Mrs. Kesselman was saying to Ruthie when Minnie entered the kitchen. "I think the bicycle is making these young women downright cruel. Just yesterday I saw a girl nearly collide with a delivery boy and you wouldn't believe what she shouted at him as she pedaled away." She handed Minnie a tray of cookies. "Ruthie wants to serve these at the party tomorrow." She punctuated this with a dark look.

After her son Edward left for college, Ruthie took up baking, which she said brought her unadulterated joy. Unfortunately, eating her unusual desserts rarely brought joy to others. Over the years Minnie had been forced to sample her friend's candied broccoli chip cookies, vinegar pie, chocolate avocado banana cake and something Ruthie called grasshopper bread, the thought of which still made Minnie's stomach churn.

"What's in these?" Minnie sniffed the cookie. It smelled safe enough. "I thought we finalized the menu last week, strawberry cakes and orange tarts?" She said a prayer the cookie was not a relative of grasshopper bread and took a small bite.

"Bicycles would help the girls get to the bakery," Ruthie said to Mrs. Kesselman. "And most doctors agree that bicycle riding is beneficial, not injurious, for girls."

"I've never heard a woman use such coarse language. The near collision was her fault, not his." 
"Generally the only people opposed to bicycle riding are those who have never tried it and therefore don't have the facts to speak authoritatively about it."

"Cheeky girl." A term of affection by now, coming from the much older Mrs. Kesselman. Minnie and Ruthie were both married women in their forties, but in Mrs. Kesselman's eyes they would always be girls. Cheeky ones, at that.

“I don't think one foul-mouthed bicycling girl should keep us from buying a few bicycles for the Home. Minnie, what do you think?" Ruthie asked.

“These are delicious," she said. "And I think bicycles are a brilliant idea. It would allow the girls to take jobs further from the Home."

Ruthie beamed. "Guess what's not in those cookies?"

"Broccoli?"

"Eggs and butter," Ruthie said triumphantly. "I can make a few dozen before tomorrow."

"Leave the recipe with Elsa Mae and the girls at the bakery can make them tomorrow," Mrs. Kesselman said.

“They've already done so much to get the house ready for the party. I'll make them myself."

"They're not here on vacation, Ruthie. These girls need the hard work."

This time it was Ruthie who appealed to Minnie with a look.

Mrs. Kesselman was fond of quoting from the Home's initial charter, that theirs was a charitable home designed to "restrain, instruct, protect and care for friendless women, in order to restore them to virtue and usefulness." She always emphasized restraint and usefulness in her recitation. The word restraint made Minnie think of a wild horse that needed breaking in.

An apt analogy, yes, Mrs. Kesselman said. 
The first year Minnie joined the Board, she and Ruthie often butted heads with Mrs. Kesselman, and they sought diplomatic, and later not so diplomatic, ways to convey to Mrs. Kesselman that it was time to make a few changes at the Home, that protection and care of the women was also part of the Home's mission. But Geraldine Kesselman had been a widow for more years than she'd been married and was unaccustomed to dissenting opinions. It made Minnie wonder what sort of man Mr. Kesselman had been. Timid and soft-spoken, Ruthie ventured during their diplomatic phase.

When the younger women made a point of learning the women's names: A waste of time, Mrs. Kesselman said dismissively.

When Ruthie suggested the inmates be allowed to relax on Saturday afternoons after sewing and working all week long: You'll turn this industrious home into a den of bone-idle sloths.

But those were minor dust-ups compared to the brawl over the bakery.

One condition of admittance to the Home was that the women promise to embrace the dual saviors of Jesus Christ and hard work, and Minnie soon discovered that the only acceptable work in Mrs. Kesselman's view was domestic work, preferably performed at her home, "Where a girl's return to virtue can be carefully supervised." It was practically a rite of passage for a girl to work at Mrs. Kesselman's before leaving the Home.

When Minnie and Ruthie proposed the Board buy the empty storefront on Fourth Street and convert it into a bakery to be managed by the women: What on earth do these girls know about running a bakery? 
Think of all the useful skills they will learn, managing their own business, Ruthie said cheerfully. Maybe they'll teach me a thing or two about baking, which Minnie thought was reason enough to open the bakery.

We don't have the money for such an undertaking, to which Minnie countered that thanks to Roland's generous donation they had more than enough money to purchase the building as well as baking equipment and supplies.

By this point, Minnie and Ruthie were in agreement that Mr. Kesselman must have been a long-suffering fool.

After one particularly fraught meeting, Minnie told Roland she feared all these arguments about what constituted appropriate work - How is managing a bakery not respectable women's work? - was liable to send her, much like it did Mr. Kesselman, to an early grave.

The next day Roland sent a letter to the Board which began, In order that the women might be restored to virtue and usefulness through hard work, I humbly request that my donation be put towards the purchase of a business that the women might manage themselves, and so the bakery was (grudgingly) purchased, with the condition that the women work at the bakery and as a domestic servant before leaving the Home. Minnie and Ruthie also (grudgingly) became more adept at picking their battles with Mrs. Kesselman, instinctively trading off whose turn it was to tangle with her. Last meeting it was Ruthie, after Mrs. Kesselman lamented that women's colleges were encouraging bluestockingism.

Didn’t your nephew marry a girl from Vassar? Ruthie asked.

Everyone knows that Vassar, unlike Bryn Mawr (a dig at Ruthie's son Edward whose latest sweetheart was a Bryn Mawr girl) didn’t fill a girl's head with erudite nonsense that kept her apart from society. 
“We musn't coddle these girls," Mrs. Kesselman said now.

"The bakery girls are already tasked with making the cakes and tarts, and everyone else has been cleaning since Monday," Minnie said. "Hard work is beneficial, but exhaustion serves no one."

"At least send me home with the receipt," Mrs. Kesselman said. "Ida can make several dozen. She's become a better cook, although she still can't wash a dish the proper way to save her life."

“How does a person improperly wash a dish?” Ruthie asked.

"Exactly," Mrs. Kesselman said.

“Did I tell you Mrs. Caperton is having a dishwasher installed?” Minnie asked.

"More trouble than they're worth," Mrs. Kesselman said. "Splashing water on dishes doesn't clean them. The whole thing is unhygienic."

"She's getting the kind in restaurants and hotels. It uses water pressure."

'Next you'll be suggesting we buy one for the Home. I'd like to be on the record opposing such a frivolous purchase."

"Duly noted," Minnie said.

"I had a thought about the strawberry cakes," Ruthie said. "What if we served salad instead? There's a growing tendency to substitute a green salad with cheese in place of heavier milk and egg desserts."

“A growing tendency among whom?” Mrs. Kesselman asked. "Rabbits?"

"Eggless and butterless cookies are one thing, but a salad instead of a cake would befuddle the poor guests. People expect cake at a silver anniversary party," Minnie said. 
"And befuddled and hungry guests don’t make generous donations," Mrs. Kesselman said. "Which, I need not remind you both, we are in desperate need of these days. That odious woman struck again.”

"Again? How many is that now?" Minnie asked.

"The Cains make nine. They gave her five dollars."

"Five dollars?" Minnie and Ruthie repeated in unison.

A woman claiming to be associated with the Home was soliciting funds from their subscribers. In the last six months, she had managed to swindle money from nine of their wealthiest patrons and they still had no idea who she was. Or how to stop her. Dark hair, fancy dress, said Mrs. Hoover about the impostor. Blonde woman with a pleasing manner, said Mr. Berry. The amount of money people willingly handed this woman was staggering. $\$ 3$, $\$ 5$, even $\$ 7$ from Mr. and Mrs. Todd. A red-headed woman with dark eyes, the Todds said.

"She must be incredibly charming," Minnie said. "I would consider it a victory if we coaxed a single dollar out of the Cains."

From the next room they heard a loud crash and a yelp, followed by a curse.

"Precisely what the girl on the bicycle said," Mrs. Kesselman said. "It's an epidemic among young women these days."

"I don't know what else we can do," Minnie said. "Last week Elsa Mae sent letters to all subscribers warning them to only give money to one of us. We ran that announcement in the paper as well. How is she still able to convince people to open their purses?"

"She's an experienced liar," Ruthie said. "She told the Todds the money was to replenish the bakery's pantry after an outbreak of weevils."

An outbreak of weevils! You had to admire the woman's brazen nerve. 
"She told the Cains the money was to purchase new cradles. According to her, we recently discovered the majority of our cribs were unsafe," Mrs. Kesselman said.

"Maybe she's someone the Home turned away years ago and she's been carrying a grudge ever since," Ruthie said.

"We rarely turn women away," Mrs. Kesselman said. "We took in that Jewess years ago, remember? Other homes said no but not us."

“An unhappy former inmate then?” Ruthie asked.

"Unhappy? These women are given a safe and comfortable home to reside in during their confinement. They're fed and clothed and all they are asked to do in return is some light sewing and cooking. Tell me how that could make a woman so unhappy she'd willfully steal money from us."

"It would behoove us to look through the admission books. It's possible a-"

“Ungrateful women, I’ve seen my share,” Mrs. Kesselman said. "But tell me how being saved from the dregs of society could make a former inmate so desperately unhappy she'd target our Home. Of course I've long believed people place too much emphasis on securing happiness these days. The surest way to be unhappy all your days is to dedicate yourself to a pursuit of happiness.”

"When I came in earlier, Elsa Mae asked after the early record books for the Home," Minnie said. "If we find those early books, we could compile a list of all the women who have stayed here since the Home's opening and see if any of them match the description of the woman."

"She's either a dark-haired woman, a redhead, or a blonde woman," Ruthie said. "That should narrow it down." 
"If there's one thing the subscribers agree upon, it's that the woman is young," Mrs. Kesselman said. "The women who lived here when the Home first opened would not currently be described as young in appearance. And as I told Elsa Mae earlier, the early books were likely lost in the move."

"I'll check with Father," Minnie said. "He might know where the books are."

"Your father has more important things to worry about these days than record books from twenty-three years ago," Mrs. Kesselman said. "I still remember the inspiring sermons he used to deliver when the Home first opened, before we even had a chapel in the Home, he would take time out of his day to drop by and instruct the girls. You'd be hard-pressed to find a former inmate who doesn't remember his erudite lectures with fondness. That reminds me, I've been meaning to visit your parents, meet their new Slavic girl."

“Svetlana been a godsend. I don't think Father could manage without her."

"I have nothing against Slavic women, but they are often so lugubrious and superstitious. Unnaturally large-boned too.”

By these standards, Svetlana would not be considered Slavic. In fact, Minnie had thought on more than on occasion while visiting her parents that if she suddenly fell ill, she'd prefer Roland hire someone less pretty and good-natured than Svetlana.

"It's such a shame that neither of your mothers can attend tomorrow's party." Minnie was surprised when Mrs. Kesselman's eyes suddenly filled with tears.

“Oh Mrs. Kesselman,” Minnie said. "If you start crying, I will too.”

“Me too," Ruthie said. “All week I’ve been thinking how much Mother would enjoy knowing the Home was celebrating its silver anniversary." 
"So many people fought the idea of this very Home. If you build it, they will sin, we were told. But your mothers believed in this Home's mission, and here we are twenty-five years later, going strong. We proved all those naysayers wrong, didn't we?"

"A number of former girls have said they will attend," Ruthie said. "It's always encouraging to see the joyful lives most women lead after their time here."

"Minnie, don't forget to prepare a little speech encouraging donations and subscriptions," Mrs. Kesselman said.

"I jotted down a few words the other night. And I plan to set a basket by the front door for donations, in case some are moved to donate more than a quarter after my rousing speech. Who knows - maybe I'll discover I'm as skilled an orator as the impostor."

“An unattended basket of money?” Mrs. Kesselman shook her head. "The things you girls suggest. You really can't be so trusting around this crowd." 


\section{From the letters of Artist Marie Bashkirtseff (1860-1884)}

Those who scoff at feminine talent can never know how many women who have taken up art seriously, women of genuine and remarkable talent, have been discouraged and their talents wasted through a vicious or incomplete education. The woman artist is quite as interesting as the man artist. It may be said that with two or three exceptions there has been no example of a woman having produced any work of art comparable to the best work of men artists. Yes, but the men receive, in one of the best schools in the world, an intelligent and comprehensive education; during the whole day they are surrounded by works of art, their eyes rest only on pure lines and brilliant colors, they breathe an atmosphere that opens their souls to inspiration and develops the wings of their imagination, on which they may soar to the heights of genius. And for women, nothing; or the chance of private studios. And why this injustice toward woman, who has proved herself a thousand times more courageous, more persevering, obliged as she is to struggle not only against the poverty — unhappily common to both male and female artists — but also against terrible prejudices and difficulties without number, lacking even the freedom of movement which men have? It is to man, who by his very nature has all the facilities for study, that all the means are given; and to woman, whom nature has deprived of freedom of movement and who has to struggle against everything, that this instruction is denied. There are too many women artists already, it may be said; woman was made for home. Alas, it is not by depriving them of the means of satisfying a noble passion that they will be inspired with a desire to spin wool. Why not afford women of ambition this glorious outlet? Why not encourage these aspirations toward the great, the beautiful, the useful? What is there surprising, then, in the fact that with two or three exceptions there have never been women artists of real importance. 


\section{Let your father and mother be glad; let her who bore you rejoice}

"I bought a new dress for the party," Ruthie said to Minnie after the meeting. They were slowly strolling home, arms linked companionably. Down the street, someone was burning a pile of leaves, and smoke curled pleasingly up above the treeline. "When I showed it to Eddie's girlfriend Libby, she said it was perfectly suited for someone my age.” Ruthie made a face. "When did I become someone my age?"

"Who on earth are Eddie and Libby?"

Ruthie laughed. "That's what Edward wants to be called now. Eddie. His girlfriend is no longer Elizabeth, she's Libby."

"Eddie and Libby," Minnie repeated. "This is what I have to look forward to - Mark and Lucas suddenly changing their names and questioning my fashion sense."

"Wait until they're taller than you," Ruthie said. "I think of Edward, sorry Eddie, as Mark and Lucas's age and now he's nearly twenty-three and has a girlfriend."

Minnie couldn't imagine her boys at twenty-three. Or someday being taller than her. "The boys turn six today. Somehow it seems they were born both yesterday and twenty years ago."

"When Edward was six he once asked me if his name had always been Edward, or if his first mother had given him a different name.” Ruthie and her husband John had adopted their son from the Home of the Innocents. They didn't know their son's exact birthdate so they celebrated his birthday on Christmas Day, the day he was left outside the orphanage.

"What a question," Minnie said. "I wouldn't know how to begin to answer that." 
"I told him that he was baptized with the name Edward Daniel Williams, so that was his real name. But he likely did have a different name. How strange that would be, to have two names."

"We have two names," Minnie said. "As married women."

"Yes, but we know our name before marriage and we know our name after marriage. Imagine not knowing the very first name you were given. Or the person who gave you that name."

People often commented on the strong resemblance between Ruthie and Edward: the same light hair, the same pale green eyes, even the same smile. He takes after his mother, strangers would say about him when he was younger.

"I find myself thinking about Edward's first mother this time of year," Ruthie said. "Surely she thinks about him too. What his name is now or what he looks like. Mother used to tell me not to think about her." Ruthie's mother had been a thin, perpetually anxious woman, made more anxious by the salacious rumors swirling around her husband. A month after his wife passed away, Mr. Norris married a former inmate at the Home, a woman younger than his own daughter. Even though Ruthie didn't like to discuss her father or stepmother, she once said it was akin to losing two parents in the same year.

"How could you not think about her?” Minnie asked. "If she hadn’t abandoned him, you wouldn't be his mother."

"We're connected, this woman and me. She's a stranger but also part of someone I love. I've always had the sense that if I passed her on the street, I would recognize her. That I would somehow know her. I used to be so fearful, when Edward was a baby, that she would return and ask for him back. But now if I met her, I would tell her that Edward is a handsome and generous 
man. That I'm thankful every day he's my son. I think it would comfort her to know that she gave him a better life when she left him outside the children's home."

Not long after the twins were born, one of Minnie's neighbors died unexpectedly, leaving behind two small boys. Minnie saw the brothers at the park a few months after their mother's death. She sat on a nearby park bench, her own babies asleep in their carriage, and she blinked back tears as she watched the boys laughing and running. Their mother was dead, but on that day, they were very much alive. Happy even. Minnie thought their mother would be comforted to see them enjoying a nice summer day. But sad too, at the realization that a dead mother did not halt the days of the living for long.

"She must have been desperate, to leave him on Christmas Day."

"I used to wonder why she never applied for admission to the Home," Ruthie said. "She would have been provided a place to stay, given a job, earned money. I don't think the Home was very good at outreach, back in those days. Not like we are today."

“There's also the possibility she did in fact apply and was turned away. I don't know if I entirely trust Mrs. Kesselman's version of events, that no one has ever been turned away," Minnie said. "The woman caring for my mother right now is a divorced Slavic woman. And a Catholic. Twenty years ago, that same woman would never have been granted refuge in the Home."

“Imagine Mrs. Kesselman's objections if we asked to admit a Catholic Slavic woman today," Ruthie said.

"It would make the bakery business look like a minor skirmish," Minnie said.

"In twenty years, if we're still on this Board, we will be the ones thwarting the efforts of the younger women. We'll find their objections to our ideas outrageous and ill-conceived." 
“God help us," Minnie said. "I was hoping to grow into the kind of woman who recognizes when her ideas are outdated and her time has passed."

"In my limited experience, no one is very good at recognizing their time has passed," Ruthie said drily. "Imagine if we could tell our younger selves, the girls who attended the Lucy Stone rally, that in twenty years they would serve on the same Board as their mothers."

"My younger self would run away screaming," Minnie said.

"I'd be depressed to learn we still couldn't vote," Ruthie said.

"God, me too."

"We're not the same people who went to that rally," Ruthie said.

"You're right," Minnie said. "Now I'm old and gray." She was only half-joking. For years her hair was reddish gold and then one day it was reddish-gray and soon it would simply be gray. There were worse things than gray hair, of course. That didn't mean that she wanted those either.

"What would you do differently? If you could go back and do it all over again?"

"Everything," Minnie said. "Nothing at all. If I told myself not to join the Board, I wouldn't have met Roland. And without Roland, I wouldn't be the boys' mother." She didn't say that she would tell herself to be more serious about her art. Or that she would tell the DirectorGeneral of course she made Bathsheba look bilious on purpose because no woman in her right mind would look mildly troubled or dreamy at such a summons.

"I would tell myself not to worry so much about, that things would work out in the end," Ruthie said. "I would say, 'Someday a baby boy in yellow and white striped booties will show up in your life and you will discover there is more than one way to become a mother."' 
Minnie had a sudden memory of seeing a baby boy in yellow and white striped booties. Whose baby? Not Mark or Lucas. She'd been worried she wouldn't be able to tell the boys apart and for a brief spell, she dressed Mark in green and Lucas in white so she could easily tell them apart. A silly concern, in hindsight - even as infants, their personalities had been different enough there was no mistaking them.

"But would you listen?” Minnie asked. "Likely I would treat an older version of myself like I did my mother, half-listening to all the pronouncements and decrees."

"Full justice in all things. Were we foolish or merely young?"

"Is there a difference?"

They passed a harried-looking woman pushing a carriage, a dark-haired baby fast asleep. Minnie had been that harried mother not so long ago, rushing home to make supper and bathe the boys, dishes, laundry, and a collapse into bed for a few hours sleep before waking at dawn, to do it all over again. Enough time had passed that now she was oddly nostalgic for the hazy exhaustion of those days. She supposed that meant that someday she would look back on the boys' obsession with war with a similar wistfulness.

"Edward looked a little like that as a baby," Ruthie said after the carriage disappeared up the street. "He had this wild dark hair that stuck straight up in the air." She held her hands above her head. "No matter how I combed it, it always looked that way. The last time Libby was at the house, I showed her a photograph of Edward as a baby and she said she didn't believe that darkhaired boy was her Eddie."

"I never knew that," Minnie said. "That Edward had dark hair as a baby."

"That's because when you returned from Paris, his hair had already turned blonde." 
"That's how I remember him. As a blonde child." Something unpleasant tugged at her, stronger this time. Nothing worse than a baby with cold feet, someone said, and the baby kicked his legs, as if showing off his new striped booties, and everyone laughed. Where had that happened?

"As a new mother I thought there might be something wrong with him, that his hair changed so dramatically. But the doctor assured me it's perfectly normal for a baby to have dark hair that turns lighter."

Perfectly normal. The baby with the yellow and white booties had been at the Christmas Eve party at the old Home, she remembered. The boy twin had this great swath of hair. His sister will covet these curls someday, someone said. Was it her? Yes. She had touched his hair, discovered it was even softer than it looked.

"How old did you say Edward turns this Christmas?" She shivered in the suddenly cool air, thought of Roland saying, Someone's walking across your grave.

"Twenty-three. I can hardly believe it myself."

Your father has more important things to worry about than twenty-three-year-old record books, Mrs. Kesselman said.

Minnie remembered a quiet woman, with carefully plaited hair and a green ribbon around her throat. They're no trouble to me, the woman said about her twins.

She can't possibly care for both of them, Minnie's mother said. She also said, Wouldn't Ruth make a great mother to the boy?

"How lucky that the Home of the Innocents knew to contact you. When they found a baby outside." Minnie was suddenly seven years old again, tugging at a loose thread on her 
stockings and watching in surprised horror as the whole garment unraveled. She was defenseless in her desire to speak what had gone unsaid all these years, buried, but not very deeply, she saw. Ruthie looked over at her. "Didn't I ever tell you? Your mother brought him by our house. She's the one who found him in a basket outside the Home of the Innocents. The sisters of the Home offered to take him in, of course, but your mother told them she knew the perfect family for him. She personally delivered him to us on Christmas Day." Minnie thought of the girl in her dream. The short-haired girl. That night she stood before the Christmas tree, with the baby boy in her arms, her hair lit up from the candles behind her. With her hair aglow like that, she was beautiful. They can't take this one, she said and then all hell broke loose.

Only now, twenty-three years too late, did Minnie understand. You can't take this one, she said except they had. My god.

What did you do, Mother? 


\section{The Courier Journal ${ }^{38}$}

\section{Happy Motherhood}

Motherhood ought always to bring happiness. But it is often the beginning of life-long unhappiness. As a preparation for motherhood, and as a preventive of the ills so often following maternity, Dr. Pierce's Favorite Prescription has been hailed as a "God-send to women." It heals diseases peculiar to women, tones up the system, makes motherhood practically painless, and establishes the sound health which insures healthy children.

"During the past year I found myself pregnant and in rapidly failing health," writes Mrs. W.J. Kidder of Hill Dale Farm, Enosburg, Vt. "I suffered dreadfully from bloating and urinary difficulty. I was growing perceptibly weaker each day and suffered much sharp pain at times. I felt that something must be done. I took twelve bottles of Dr. Pierce's Favorite Prescription and also followed his advice. I began to improve immediately, my health became excellent and I could do all my own work (we live on a goodsized farm.) I had a short easy confinement and have a healthy baby boy."

Dr. Pierce's great work The People's Common Sense Medical Adviser (paperbound copy) is sent free on receipt of 21 one-cent stamps to pay cost of mailing only. Address Dr. R.V. Pierce, Buffalo, N.Y.

38 August 1901 


\section{Every dog has his day}

Minnie stood by the kitchen sink, the dinner dishes floating in the rapidly cooling water. She'd pulled out the good china to celebrate the boys' birthday. White with a blue hawthorne border, the plates were a wedding gift from her mother. Minnie had preferred the set with the dark blue border and band of gold, but her mother said gold borders were unlikely to be in style in a few years. Had she genuinely preferred the dark blue plates or had she trained herself to desire that which her mother didn't? Impossible to know at this point, so tightly braided were the two.

Out the window she spied the boys' dog Bandit on the back porch, watching the boys play. Weren't dogs supposed to jump about and bark? Not this one. He'd shown up at their house one day, matted yellow fur, bloodied ears. Roland had patiently washed him in the backyard. Careful, he might bite! she called from the porch. Soon the dog was hanging around - Let's call him Bandit, Roland suggested, and the boys helped Roland build a doghouse. Lucas even donated one of his blankets to keep Bandit warm. He has a fur coat, she said in exasperation. She was the only one who found Bandit's silent presence unnerving. How much protection did a silent dog offer?

"Bombs away!" Roland shouted from the backyard, and the boys screamed and chased after their new toy, a giant cucumber balloon which wriggled about as if alive when thrown up in the air. She'd bought it at the new toy store downtown. In the front window of the store had been a detailed dollhouse, with a second-floor piazza decorated with tiny flowering plants in pots and a telephone in the library, even a miniature hat rack in the hallway. While Minnie was paying for the boys' present, a young woman came into the store to buy the dollhouse. She didn't seem old enough to be married, much less have children old enough to play with such a toy. I hope your daughter enjoys it, Minnie said to the young woman. I spent hours playing with my dollhouse as 
a child, and the woman laughed and said it wasn't for her daughter but for the children at the Home of the Innocents, and Minnie told her that she had a friend who made a donation to the Home every Christmas, and she'd left the store feeling that the world was generally full of decent people.

All the familiar objects in her kitchen - the flour sifter with the green handle from her grandmother, the rolling pin from Roland's mother, the skillets and the ladle and the pots and the pans - what she would have said made hers a home, rather than a house, were suddenly unfamiliar. Even the dishes lolling about in the sink were suspect. Why did she have all these things? What was the point of them, really?

Next week the dishwasher arrived at Caperton house, and it would be her job to explain to Mrs. Caperton, who would then explain to a servant, how to operate the fancy new machine. Minnie had been good at arithmetic when she was in school, better than most of the boys but those same boys had grown up to be engineers and architects who designed fancy machines and expensive houses and she, who once went an entire year without missing a single problem on a single test, had grown up to be a wife and mother tasked with explaining to other wives and mothers how to operate their fancy machines in their even fancier houses. She had grown up to manage the finances of the same Home her mother once managed, and her skills were used to secure money to purchase bakeries and cradles, baby blankets and new furniture. Money for this, not for that.

What she wouldn't give to solve a simple arithmetic problem right now.

Q: On Monday, Maud sold 3/7 of her pears; on Tuesday, she sold 16 more than 1/2 of the remainder, and had 20 pears left. How many had Maud at first? Q: A piece of cloth measured 12 2/3 yd. before sponging and $115 / 6$ yd. after sponging. How much did the cloth shrink? If you did 
it correctly, you could always learn how many pears Maud had on Monday, how much your cloth shrank after sponging.

Q: A girl had 2 babies. The next day a woman took one away. Who is the boy's mother?

Andrew, Augustus, Arnold. Benjamin, Charles, Calvin, David, Daniel, Donald. She would know the baby's name when she stumbled upon it.

On the kitchen counter were the remaining slices of cake. Not her best effort, although the boys hadn't cared. After making such a fuss about baking the cake, she had no memory of making it. It was lopsided and crumbly so she must have iced it while it was still warm. Who told her that - never ice a still warm cake? Who knew. It was something she had learned. Mark wanted to feed a slice to Bandit but Roland told him dogs didn't like cake. Imagine sharing food from your table with an animal. Minnie had seen a woman in Paris do just that, slip food to the small dog in her lap, and she'd laughed aloud. I've seen it all, she thought that day.

If she could only remember the baby's name, the way she remembered that woman feeding her dog.

Franklin, Gregory, Henry, Harold, Isaac, John, Lucas, Mark.

Earlier when Roland handed her a slice of cake, she lied and said she was full. Impossible to swallow past the tightness radiating from her stomach up to her throat. This morning she had done these things - talked, swallowed food, washed dishes. This morning the objects in her kitchen had not confused her. From her spot by the sink, she watched Mark suddenly snatch the balloon out of Lucas's arms and then the boys dropped to the ground, wrestling for control of the balloon. Roland stepped between them and took the balloon. He said something she couldn't hear and the boys stood up. Lucas thrust out his hand and Mark did the 
same and their grudging handshake quickly became silly, their small arms pumping wildly, and when Roland threw the balloon again, they raced after it, their anger forgotten.

She had been so wrapped up that Christmas in her upcoming trip to Paris, she had been so focused on herself she had not thought to ask any questions when she returned that spring and Ruthie suddenly had a baby. What a convenient story - a baby found outside an orphanage on Christmas Day.

Matthew, Nathaniel, Patrick, Phillip, Richard, Robert, Samuel, Sebastian.

A few months before she and Roland married, she told him she was thinking of keeping her maiden name. That's what Lucy Stone did, she said. Someone like Marie's husband Felix might have erupted in anger but Roland had said it was her decision, and later she read that Lucy Stone was not allowed to vote in Massachusetts, after the legislature approved suffrage, because she hadn't taken her husband's last name, and so she'd changed her name.

He's a good soul, her father said when he met Roland.

Timothy, Theodore, Thaddeus, Victor. Walter, William.

William. Yes.

If she had regrets, it was not about changing her name.

As if a spell had suddenly broken, she plunged her hands into the sink and washed the dishes, drying them as carefully as if they were a newborn baby. 


\section{Balloon travels}

After bath time, a fight broke out about who could sleep with the balloon.

"No one will sleep with the balloon," she said firmly. "Balloons don't belong in the bed." While she was hiding the balloon downstairs, the boys got into a different fight over possession of an imaginary Bandit-shaped balloon, and she told them if they didn't stop arguing, she would throw away both the imaginary and real balloon.

"We're pretending," Mark said. "You can’t be cross with us for using our imagination."

"You can sleep with the Bandit balloon," Lucas said magnanimously to his brother, and Mark made a big show of making room in his bed for the imaginary balloon, even pretending to tuck it under his quilt.

She read the boys their favorite book, about a group of friends who tour Europe via hot air balloon with their Uncle Robert. Mark was asleep before she reached the second page of the story. Lucas, however, remained wide awake until the end.

"Our Uncle Robert would never take us on a balloon ride," Lucas said.

"No," Minnie agreed, thinking about the uptight man who married Roland's sister Sarah. "He's not the type to take children on a tour of Europe in a balloon."

"Maybe when we're older," Lucas said.

"Ever the optimist, you are," she said to him. "You've had a big day, haven't you?"

"Mark and I will always have the same birthday," Lucas said. "That's fine because Mark is my favorite brother."

She smoothed his hair back from his forehead. "Silly you. He's your only brother."

"But if I had another brother, Mark would still be my favorite." 
As an only child herself, she hadn't been prepared for the bond between the boys, how they often acted as one mind with four legs and arms. As babies they slept in the same crib, facing each other. As toddlers they babbled away to each other in their own language. They'll never learn to speak properly if you allow them to speak nonsense to each other, her mother said. Mark had a clockwise whorl in his hair, Lucas a counterclockwise one. Once she was in the kitchen with Lucas and Mark fell upstairs and scraped his knee on the bed and before he even started crying, Lucas pointed at his own knee and cried out: It hurts! Impossible to imagine the one without the other. She pinched the fleshy part of her hand, between thumb and pointer, to hold back her tears.

How young the boys were, how old they thought they were. Some day they would smell like men - sweaty, busy, important men - but tonight, even after a bath, they smelled of chocolate cake and grass.

You won't break them, babies are sturdier than they look, her mother said when she saw how gingerly Minnie held her newborn twins.

It was her own heart that wasn't so sturdy, she saw now. No one told her that happened when you became a mother. Likely she wouldn't have believed them anyway. She'd made a painting soon after she discovered she was pregnant. She was inordinately proud of it too, even if the execution was less successful than the idea. She sought to capture herself from every angle: above, below, straight on, from behind, from the side, from the inside. A woman as she saw herself, and as seen by the world. Portrait of a Woman, she titled it. She turned herself into a series of overlapping shapes, and in her reduction was transformed into something more powerful, more substantial. 


\section{The obstruction}

Such a thin line between a high-spirited girl and a rebellious one, the line a result of chance, opportunity, timing. Money too. High-spirited girls succeed, rebellious girls fall. At fourteen she felt faint at the presence of blood down there and then, at age twenty, she was faint at its absence. All the things a person learns to accept and expect from the body. Hooper's Female Pills for Nervousness and Headaches contained six pills but it only took three to dislodge the obstruction when she returned from Paris. She kept the remaining three as a reminder. Or was it a talisman? Doubtful they still worked after all this time. Best not to know what was in them. The last time Roland saw the green bottle in their bathroom he asked if the pills helped with headaches, and she said, Oh yes. Worth every penny. 


\section{The impostor}

So far she has claimed to be raising money to build a gymnasium for the Home for Newsboys and Waifs ("A well-equipped attraction to keep the little urchins off the street"); a library for the Young Women's Boarding House ("You've never seen such hard-working and noble girls"); new cradles for The Home for Friendless Women ("They convert into a swinging crib which can be operated with a foot pedal"); and new typewriters for the Kentucky Home for the Blind (“The blind are frequently taken for imbeciles but nothing could be further from the truth - some of these girls can type as fast as you or I.") With each donation, she mails half to Sister Frances at the Home of the Innocents. Sister Frances who all these years has kept the yellow and white striped booties Sophia was wearing the day she was left in a basket outside the Home. My Christmas miracle, Sister Frances said.

Every Sunday, Sophia visits the Home, and the children watch anxiously for her arrival, their faces pressed to the window as she walks up. Oh you'll spoil them rotten, Sister Frances gently chides when Sophia brings them candy and new clothes. She has already bought a Christmas gift for the girls, a cunning little dollhouse with porches and a small front lawn, and in the library, a tiny imitation rug with an animal head. There's even a hat rack in the front hall, complete with tiny hats hanging from its pegs.

Sophia doesn't know what she will do with the rest of the money. She would like to travel, but not until Sister Frances is gone. Then she will take a boat across the ocean, she will eat foods with foreign-sounding names and she will fall in love with a handsome man. This handsome man will find her clever and beautiful and he will never ever feel sorry for her, even when he learns who she is and where she came from. God, she can't stand for people to feel sorry for her. 
With all this money she could start her own home.

A Home for Motherless Women

A Home for Adult Orphans

A Home for Women Who Know What They Want But Don't Know How to Get It 


\section{A truth that comes too early or too late is shaped like a lie}

Her parents were seated at the breakfast table when Minnie arrived the following morning. She'd hardly slept, flopping from her back to her side, until finally the sun thrust light through the bedroom window, and she could slip out of bed without arousing suspicion.

You're up early, Roland mumbled sleepily, and she said she needed to collect something from her mother before the party, how easily the lie slipped from her mouth, and he was asleep again by the time she was dressed, quietly closing the door behind her.

Her mother pointed at the newspaper on the table. "Whatever happened to that man?" She addressed the question to no one in particular but looked from Minnie to her husband. "The one who went to the theater that day?" Even with her hair combed and her clothes straight, a sense of dishevelment clung to her. It was her eyes that betrayed her, alighting in confusion on the people near her. They were similar to the eyes Minnie had given her mother years ago in the painting, too wide and blank.

"You're thinking of John Wilkes Booth," Minnie’s father said. "He died not long after shooting President Lincoln." McKinley's assassination had prompted her mother to continually revisit Lincoln's death.

"Yes." She nodded vigorously. "Booth, yes. That was a sad day."

"A terrible day for our country," her father agreed.

She rubbed his fingers across the surface of the paper and studied the ink on her fingers.

“Mrs. Davidson, no,” Svetlana said, appearing out of nowhere, as Minnie's mother went to put her ink-stained fingers in her mouth. "Use your handkerchief."

"My what?" 
Svetlana handed her one and mimed wiping her fingers on it, and she obediently followed.

"I made that for you when I was learning to embroider," Minnie said.

"And who are you?"

"I'm your daughter. Minnie."

“Are you Minnie too?” she asked Svetlana who shook her head.

"When I struggled with embroidery," Minnie said. "you would tell me, 'Whatever your hand finds to do, do it with all your might, for in the realm of the dead where you are going, there is neither working nor planning nor knowledge nor wisdom."” Everything was weighted with extra meaning, nothing held its original shape anymore, not even Ecclesiastes. "You used to say Ecclesiastes asked the most of us, but it also gave us the gift of accepting God's will."

"Who said that?" Minnie's mother asked.

"You did," Minnie's father said. "You used to say all sorts of wise things, Eliza."

Once during a game of hide and seek with her cousins, Minnie hid in her parents' bed.

She pulled the comforter over her head and lay there, still and silent. The sheets smelled different in their bed, deep and dark, not the smell of her own bed at all. She thought of how her mother looked at her father when he was delivering a sermon, the noises she heard from their bedroom at night. What a shock she'd had, years later, when she recognized that same smell in her own marriage bed.

"Well isn't that something," her mother said. Her laugh was free and easy, so like the boys' laughter as they played with their cucumber balloon. She wondered if this was what her mother had been like as a little girl. What Minnie knew of her mother's childhood would not fill half a page. Raised by an aunt and uncle, and then sent to a girls' home, and then marriage. 
Everything else was a mystery. You mustn't pry, her father told her. She doesn't like to revisit the past.

Minnie didn't want to revisit the past either, but she was hurtling towards it, and there was no stopping the inevitable collision.

"What brings you by so early, Min?" her father asked.

"The matron of the Home is reorganizing the library ahead of the silver anniversary party and she can't find the first record books. I thought I might look around the house, see if Mother kept them here, for some reason." For some reason. She studied her father's face to watch his reaction, but his face didn't change.

"That doesn't sound like her, to be honest." He slathered butter onto his toast and even though she hadn't eaten since lunch time yesterday, she realized she wasn't hungry. Maybe she would never eat again. Maybe she would waste away and then it would be someone else's job to find the books and attend the party and right the wrongs of the world. She wasn't hungry, but she was tired. Exhausted. If only she could crawl back into bed and hide from the world. She'd had a friend who did just that after giving birth to her second child, refusing to leave her bed for months and months. By the time she finally got up, she walked like a much older woman.

"A place for everything and everything in its place," her father said, quoting one his wife's favorite sayings. "Although this senile dementia was likely affecting her long before we noticed. She managed to hide it from us. Such a smart woman."

"Stubborn too," Minnie said.

"She didn't have the easiest childhood," her father said.

"She had a very comfortable life as the wife of a reverend."

"Now Minnie-" 
"I know, I know," she said. "Be patient with her." How many times had her father said that to both her and her mother? But patience hadn't been in either of their natures.

"Mother, do you remember where the books from the Home are? The ones from the first two years it was open, 1877 and $1878 ? "$

Her mother tapped the paper, now upside down in front of her. "Do you remember what happened to that man?"

After her parents and Svetlana left for a walk - Svetlana says daily exercise is good for the body and mind, Mr. Davidson said, patting his soft stomach - Minnie started in on the bookshelves in her father's study. As a child, the room where her father retreated to write his sermons had been off-limits to her. Even now she felt like a trespasser, although if the lack of dust was any indication, this room was regularly cleaned by Svetlana. The books in here were organized by color, her father's preferred method. She knew she was not going to find the book carefully arranged on the shelf behind her father's desk. But she wanted to be thorough. Methodical. Conscientious. And so she pulled out each one, starting with the green books on the left and working her way over to the red ones.

How did you know you wouldn't be happy unless you gave the money away? she once asked Roland, and he thought a long moment before answering. She used to think he was weighing his words carefully but now she knew that was just his way. It was the right thing to do, he said. You recognize the truth by its own sound.

She moved from room to room, opening drawers and cabinets. Not in the study, not in the living room. She had a moment of euphoria when she found a weathered book wedged behind the silver urn in the dining room sideboard but it turned out to be an old recipe book from her 
grandmother. Her mother used to complain that Granny's cooking always featured lard - lard in gingerbread, lard in green beans, lard in custard pies. Minnie had never minded her Granny's cooking.

"Still at it then?" her father asked when they returned. "It's getting cold out there," he said. 'If I didn't know better, I'd say it might snow tonight. Wouldn't that be something, Eliza, snow in September?"

Her mother looked at Minnie, kneeling on the floor by the sideboard. "What's that girl doing down there?"

"She's looking for some old books," he said.

"I know her," Mrs. Davidson said. "We were at the girls' home together." She lowered her voice. "An uppity girl, we didn't get along that well."

After her parents left the room, Minnie noticed Svetlana had stayed behind. The woman suddenly kneeled beside her, and Minnie looked over in surprise; Svetlana's face was so close she could smell her violet perfume. "I think I know where your books are," she whispered.

The attic stank of mothballs and the chloride of lime solution her mother used to clean the floors and the trunks. While Svetlana was rummaging in the corner for something, Minnie opened one of the windows, and breathed in the cold outside air. God she despised the smell of mothballs. As punishment, Minnie was once sent up to clean the attic and she'd purposefully neglected to add fresh mothballs to her trunks. The following year she'd found a dead moth sitting atop her favorite gown and best cape. A job half done is as good as none, her mother said unsympathetically about the ruined garments. 
"I found this box when I was cleaning out my room," Svetlana said. "Your room," she corrected. She handed Minnie the box. "I moved it up here."

“Thank you," Minnie said.

"I wasn't trying to hide it."

"You did fine," Minnie said, and then, as if sensing Minnie wanted to be alone, Svetlana quietly climbed down the stairs.

At the top of the box was her old diary, a gift from her father when she turned seventeen. Likely he'd hoped she would use it to record her favorite Bible verses, and instead she'd carefully recorded dinner party menus and potential beaus. After she lost it, she told her mother it was a sign she shouldn't marry. She'd been joking, of course. She'd wanted to upset her mother and she'd succeeded. The cover was soft, still the deep purple she remembered. She continued to dig through the box, nearly slicing open her hand on a pair of rusty shears. An empty liquor bottle unpleasantly grimy to the touch. A pair of rusty scissors. Why on earth had her mother saved this odd menagerie? At the bottom, she found what she'd been looking for, she immediately recognized the faded red leather book with its cracked cover. It was the same book that she remembered seeing on her Mother's desk or tucked under her arm when she left for Board meetings. A place for everything and everything in its place. The book made a sigh of defeat when Minnie opened it; inside was her mother's tidy, tiny handwriting. You know the truth by its sound.

The entry she was looking for was between a discussion about the Matron's salary - Some of the ladies feel the amount disproportionate to our means - and an announcement about an upcoming lecture at the Home over the curiosities of ancient Egyptian art. 
January 3,1878 - Two women have been sent to City Hospital, one to Insane Asylum, one expelled

There was only the one asylum in town, the official name was the Central Kentucky Asylum for the Insane, but most called it Lakeland Asylum, or even just Lakeland. Every few years the hospital managed to make headlines, most recently for dumping raw sewage into Goose Creek. As Minnie dimly recalled, the commissioners had been indicted on charges of infecting the water supply.

A few years ago, Roland's firm put in a bid to build the new addition at Lakeland, and that night, he told Minnie that he hoped they didn't get the job because he never wanted to return to Lakeland. The smell, he said. No matter how many times Minnie washed the shirt he wore that day, he claimed he could still detect it. She didn't argue with him because she knew what it was for your clothes to carry a memory. She hadn't been near the girl when she cut herself, and she never found a single drop on her clothes, but she also understood her dress was indelibly tainted. Poisoned by the blood of another.

The girl with the braids and the ribbon around her throat had gone to bed a mother to twins and the next morning she had been sent away for refusing to give up one of her children. She had been hauled away to a place that Roland, years later, would say smelled worse than death. The smell of those barely living, the body reluctantly carrying on as the mind wandered far, far away. And she had been sent there by Minnie's mother.

If the twins' mother were here before her, Minnie would say, I know where your son is. She would say, His mother loves him very much, and I'm so sorry for what my mother did, and How can I make this right? 
That Christmas she and her father made breakfast while they waited for her mother to return from the Home. She works so hard, her father said as Minnie prepared their breakfast. She felt unexpectedly tender for her mother that day, that instead of eating cheese turnovers with her family, she was cleaning up blood and restoring order to the Home. She cares too much, Minnie's father said.

No rest for the wicked.

How do you find a girl with no name?

"Ask, and it shall be given to you; seek, and you shall find," her father said cheerfully when he saw the box in her arms. The people she passed on the street looked up at the sky in wonder, as if they had never heard of the idea of snow, much less seen it. 


\section{The mother}

She never learned to swim. People didn't do that sort of thing when she was a child, not where she grew up. But she has a feeling she would have liked floating in the water, she has a feeling she would have been good at it, that her arms and her legs would move effortlessly, instinctively. Row row row your boat. She found pills in the girl's bathroom, hidden inside a box of old rags. But she didn't say a word. Not one word. And now the words are there and gone, gently down the stream. How far she has floated from everyone, the girls she grew up with are waving from the shore. Merrily merrily merrily. If they're surprised at how good she is at floating away, at becoming someone else entirely, they keep it to themselves. Whatever happened to that man? No one will tell her, no one knows. 


\section{The silver anniversary party}

"Cora's the one who came up with our new advertising campaign. Give her time! You've seen it, I'm sure. With the child carrying a grandfather clock?" Mr. Pearline pretended to stagger under the weight of an enormous clock, and Minnie politely laughed.

“'Give her time and almost every soap-using woman will come around to the use of Pearline'," Cora Pearline recited. “"There's ease, economy, quickness, health and safety in Pearline washing and cleaning.' I told George that a product that claims to make a woman's life easy and is good for her health will practically sell itself." Cora looked like she would right at home in a Rubens's painting, with her blonde hair and fleshy arms. Her silver and gold dress was clearly expensive and wildly impractical for the sudden cold weather, the folds of silk carefully encasing her curves.

Behind the Pearlines, Minnie could see Victoria playing the harp. Even with her substantial bump, her arms moved gracefully, seemingly effortlessly, over the strings, her eyes closed as if she had been transported somewhere else. Minnie's mother had forced piano lessons on her and worse than the mind-numbing scales was the humiliation of being trotted out like a show pony to play for visitors. She would pound ungracefully on the piano, as if to prove that artistic talent could be cultivated, but real passion couldn't be learned. Or faked. Minnie wondered where Victoria had learned to play; she'd never thought to ask. Mrs. Kesselman had opposed the idea of a concert, claiming it would be unseemly in her current condition, but Minnie and Ruthie had insisted. A small crowd had gathered to listen to Victoria's playing, and Minnie was happy that for tonight at least, Victoria was allowed to forget where she was, be transported somewhere else through the beauty of her playing. 
"The Home is so appreciative of the soap you send every year," Minnie said to the Pearlines.

"It's important to give back," Cora said. Such a round, youthful face. Minnie remembered that she had been practically a child herself when she was in the Home. She had a sudden memory of sitting beside her on the old sofa, and how tightly Cora had gripped her hand as the short-haired girl lay on the floor, bleeding. "This house is so much grander than the old one. One of the girls gave us a tour and I couldn't believe the size of the bedrooms. Easily twice as big as the one I had."

“Were you happy at the old Home?” Minnie asked. She didn't dare ask Cora what she really wanted to know.

"Well," Cora said in surprise, "Is anyone happy during pregnancy?"

"No," Minnie said, and Mr. Pearline chuckled uncomfortably.

"It's a shame our daughter Grace couldn't join us. She's busy planning her wedding these days." Cora practically radiated pride. "A big society wedding. I wouldn't be surprised if there's a write up in the newspaper."

"She's a very pretty girl," Mr. Pearline said. "She could have had her pick of anyone in the state, you know. Clever too. She came up with the Doing stunts campaign: 'You can stand on your head, for instance. Almost everyone could do it if it were necessary or desirable. But standing on the feet is more natural and more sensible - and easier. So it is with soap and Pearline'."

"I’ve seen that one," Minnie said. "My boys always try to imitate it."

“Well, it’s a family business,” Mr. Pearline said, pleased. 
"One of the girls told me she works at a bakery," Cora said. "That sounds divine compared to working for Mrs. Kesselman." She lowered her voice. "Once after I cleaned her kitchen, she suggested I walk around with a damp cloth to catch any dust before it fell."

“Unbelievable,” Minnie said. "And entirely believable.”

"I should be thankful to Mrs. Kesselman then," Mr. Pearline said. "If she hadn’t fired you, you might not have applied to work for the Pearline company."

"I was a good stenographer," Cora said. "Better than I was at sewing, that's for sure. I feel sorry for anyone who had their curtains mended by me. My stitches were never as neat and tidy as the other girls."

Minnie wanted to ask Cora if the twins' mother had been a good sewer. Instead she told the Pearlines they should be sure to try some of the baked goodies from the bakery and she hugged them both before moving easily through the crowd, greeting guests and smiling as if there really was a reason to celebrate the Home on this snowy evening.

"I noticed someone put a basket by the front door," Mrs. Kesselman said to Minnie. "For donations." She bit into a white cookie and powdered sugar promptly dusted the front of her silvery-gray dress. "The bakery girls call these snowball cookies. Fitting name for a dessert tonight, isn't it? I'm glad to see this weather has not kept people at home, we've had a larger crowd that I expected." She brushed at the sugar on her dress. "Still, I asked Ruthie if Edward could keep an eye on the money basket."

Minnie looked over and spotted Edward in the hallway. He yawned and rocked back on his heels, casting a longing glance at the grandfather clock. Clearly standing guard over a money 
basket at a silver anniversary party was not where he wanted to be, but he was there because his mother had asked for his help and he was a good boy.

A good man, Minnie corrected silently.

"He wants to be called Eddie now," she said.

Mrs. Kesselman laughed. "I can ask people to call me the queen of the Nile but that doesn't mean it's my name. His name is Edward, and that's what I'll call him."

"I believe his name is William." Minnie felt the same jolt of surprise she'd felt six years earlier, when her water broke during her daily walk by the river. What had been abstract that morning was suddenly and painfully real. Oh this is happening, she thought.

“William?” Mrs. Kesselman didn’t look guilty so much as confused. Minnie wondered if this had been such a common practice, taking children from their mothers, sending girls who disagreed with them away, that it was akin to asking a person to describe in detail what they wore on a Wednesday ten years ago. "What are you going on about?"

"He had a twin and his mother named him William. Before my mother gave him to Ruthie, his name was William.”

"Your mother found Edward outside the Home of the Innocents and she brought him to Ruthie who had been trying to have her own children for years."

"I found the old books."

This time Mrs. Kesselman didn't look confused, but she didn't look guilty, either. Minnie felt a surge of anger, so pure she felt it in the burning numbness of her fingers and toes. This raw emotion had forced its way to the outside of her body, too unstable to be fully contained.

"You should think carefully about who would be hurt the most by your discovery of these books. Because it's not you,” Mrs. Kesselman said. 
“Don’t lecture me, Mrs. Kesselman, as if I were one of your wayward girls improperly washing a dish. Because that is all I have been thinking about. As a mother. As someone on this Board. As one of Ruthie's oldest friends."

Mrs. Kesselman sighed and put her plate down on the table. Minnie dimly noticed that the punch was dangerously low as were the tarts. Ruthie's cookies were mostly untouched. Something must be terribly wrong with her, she thought, that she could still notice these things.

"We cannot be charitable to our equals," Mrs. Kesselman said. "And so we are forced to make decisions that, from the outside at least, appear difficult and messy. Look around you, Minnie," she said, suddenly serious. "Look at all these women who have returned to celebrate our silver anniversary. They are not here to eat snowball cookies or hear that girl pay the harp. They are here because when they had nowhere to go, when they were scared and alone, we gave them a place to stay. We gave them a new life. These women went from friendless, wayward girls to pious and decent Christians. Cora Pearline was fourteen years old when she showed up here, and now she's the heiress to a fortune. That woman over there came here from Madam Sewell's or maybe it was Madam Mollie's, I can't remember, and now she lives in Florida with her husband and their five children. That girl over there is now a dentist in New York City. The point is, we found husbands for these women, we found jobs for them, we gave them a new chance at life. When everyone else gave up on them, we believed they were capable of repentance."

"But at a cost," Minnie said, her voice rising. A few guests turned and looked over at them. "Our help came at a great cost for some."

"All help comes at a great cost, Minnie." She briskly wiped her hands on a napkin. "I'll ask one of the girls to bring out more punch and tarts." 


\section{The ever-changing world}

The cold air was welcome after the warmth inside, and Minnie breathed deeply as her eyes adjusted to the darkness. She turned and studied the house behind her, as if seeing it for the first time, as if memorizing its every angle and curve so she could to faithfully re-create it later. She tried to look at the Home as if she were a girl who had exhausted all other options, a girl with no money to buy pills, a girl without relatives to take her in for nine months, a girl whose stomach grew and tightened a little every day. She imagined lifting her hand to knock on the door, the weighty pause. Was this truly the only option? Then, the knock on the door, quick and decisive, before she could change her mind. The terrible fear of being turned away, the terrible fear of being admitted.

Across the street, standing just outside the glow of the gas lamp stood a woman. Minnie watched her watching the Home, and then, she crossed the street to stand beside the woman. The woman's hair was wet with snow, as if she had been there awhile. She wrapped her scarf tightly around her neck and when she turned to look at Minnie, she had a plain, proud face.

"I didn't think I would come," the woman said. Her cheeks were wet from the snow. "But I was too curious to stay away when I received the invitation for the silver anniversary party."

"Did you live here?"

"At the old Home, when it first opened. I heard this place has a chapel."

"It does." Minnie didn't add that it was named after her father.

"We were allowed out of the house once a week, for Sunday services. I could probably still recite Psalms 25, I read it so often while waiting for services to start.”

Minnie remembered watching the women file in on Sundays, their stomachs preceding them as they slid, one by one, into their pew at the back of the church. 
"Were you an inmate here too?" the woman asked, and Minnie shook her head.

"I'm on the Board. Treasurer."

"Is the Home still in financial trouble?"

"It's better now. The girls work at a bakery over on Fourth Street. They run it themselves." She spoke quickly, too quickly, tripping over the words in her haste to say them in case the woman suddenly vanished. "It brings in more money than sewing, at least."

"I never minded all the sewing," the woman said. "I found it oddly comforting after a long day. I was expelled from the Home.” The woman said expelled with a practiced flatness. "On Christmas Day."

Two women sent to City Hospital, one to Insane Asylum, one expelled

The woman looked at her, and Minnie was suddenly fearful the woman recognized her, knew her to be Mrs. Eliza Robinson's daughter. "Do you have children?” the woman asked.

"Two boys." She didn't dare speak the word twins.

"I had a daughter. She's twenty-three now."

"What's her name?"

"I named her Kate, after my friend. I don't know what her new parents named her."

Minnie nodded, as if she understood, even though she didn't understand anything.

"At the hospital they said I shouldn't hold her, that it would things harder, but I did. It was the right thing to do. She had the tiniest ears, like shells.”

"I'm sorry," Minnie said and then was sorry she spoke at all, so meaningless were those two words. 
"It was so long ago," the woman said. "It was twenty-three years, and it was just yesterday. Now I'm a wife and a nurse and I found I needed to see if this place really existed, or if I somehow dreamed it all."

They stood there in the cold, both staring straight ahead, as if waiting for a train or a carriage to take them somewhere else.

"Sometimes I still dream about the girls in the Home. In my dreams we are always sewing curtains. They sent my friend Kate to the asylum. I tried to find her, years later, but she wasn't there."

"We don't do that now," Minnie said helplessly. "Send women to the asylum." Kate, Kate, Kate she repeated inside her head.

"Sometimes I can almost convince myself she was released and reunited with her children. She was a worrier. But an optimist too. She always found a way to see the goodness in others, even when they failed her." Her voice made clear that she believed herself to be one of those that had failed Kate. "I hope that whoever ended up with her children baptized them. That mattered to her. It mattered to her a great deal."

Minnie told her, without saying a word, that the son had been loved and cherished. Baptized too, she had been there that day, standing beside an exhausted and happy Ruthie. She was sorry. She was so very very sorry.

It wasn't this woman's job to assure her of a thing, and still, Minnie fought the urge to ask for forgiveness. Soon she would go inside and she would give her speech asking for donations and she would talk with subscribers and former inmates, and she would decide what she owed Ruthie and what she owed a woman and fellow mother she didn't remember. The truth 
was a burden she couldn't carry alone. It seemed possible she might stand on this street corner forever, in the in-between space before her own life became a before and after.

"I remember thinking on those nights we sewed curtains that the Home was a passing through place, it was a stop on my way somewhere else. But it was never my home.” The woman sounded like she was teetering between laughter and tears, and she seemed surprised herself when she started laughing. "It was never really a Home for Friendless Women."

"It was a house," Minnie said. And then she was laughing too, beside this stranger. Her face was numb from the cold and she reached her hands to her face, as if to reassure herself that she was still there.

"A house for Magdalens." The woman lifted her face to the sky as if in prayer. "A house for fallen women."

Minnie lifted her own face as well. All the women who had passed through the Home, the ones she knew and the ones she never met. Twenty-five years of births and deaths, tears and laughter, of dreams and dreams and dreams. She said a prayer for all those hurt by their time in the Home, and she asked forgiveness for all those who inflicted suffering in the name of salvation.

No, the dead do not halt the days of the living, but they transform those left behind, they ask them to never forget, and in this way, the dead are finally granted a place of peace, an eternal home of remembrance.

The two women stood like that for a long, long moment, as the September snow gently kissed their upturned faces. 


\section{The Courier Journal - May 1919}

The Salvation Army to extend its work! Of the \$57,000 asked for the Salvation Army, and no word of praise needs to be given to this splendid organization - $\$ 27,000$ is to clear off the past-due mortgage on the Citadel; $\$ 15,000$ is to for repairs and needed additions to the Citadel; and $\$ 15,000$ to put in shape the Home for Friendless Women, Louisville's only home for unmarried women, which is to be taken over by the Salvation Army next month. The work of solicitation will begin next Tuesday. Be ready for the workers. Make this gift a gift for the uplift of Louisville's unfortunates. 


\section{BUT WHAT WAS SHE WEARING?}

Many women are told, as I was in my youth, that something we did or said or wore or just the way we looked or the fact that we were female had excited desires we were therefore contractually obligated to satisfy. We owed them. They had a right. To us.

- Rebecca Solnit, Men Explain Things to Me

In January 2015, conservative Christian blogger Veronica Partridge posted an article titled "Why I Chose To No Longer Wear Leggings," a decision, she explains, stemming from concern that wearing tight, thin pants out of the house might elicit lust in other men:

If it is difficult for my husband who loves, honors, and respects me to keep his eyes focused ahead, then how much more difficult could it be for a man that may not have the same self-control? Sure, if a man wants to look, they are going to look, but why entice them?

Modesty is discussed, debated, dissected in the nearly thousand comments that follow. Is it a woman's job to keep a man's libido in check? 'Ladies we ARE responsible to dress modestly as not to make our brothers stumble," one woman writes. "Modesty is not about helping men," says another. "It's about respecting ourselves as women."

At my daughter's high school, it's largely the girls who are punished for violating the dress code. Some girls keep extra clothes in their locker for this reason. Boys that wear low slung pants, their underwear clearly visible, might be asked to pull up their pants, but are rarely sent home to change. 
When I taught high school many years ago, a student came into my classroom one Halloween, crying, after an older teacher stopped her in the hallway to criticize her costume. This student wanted to know what I, the newest and youngest teacher at the school, thought about her sexy devil outfit. The teacher who took issue with her costume had recently stopped me on a casual dress Friday to ask what I was doing out of class without a hall pass. When she realized her mistake, she said that in my jeans I looked just like a student. Her tone of voice made me feel defensive and young, and made her sound, to my ears, out of touch and old.

I don't remember the name of the teacher who mistook me for a teenager, but I remember the name of the crying student and I also remember how, as she waited for my answer, she hardly resembled the outspoken and bawdy girl she often was in my class. You look just fine, I said about her costume. It was the only acceptable thing to say.

A thread of fear lurks underneath the women responding to Partridge's post. Several share that no matter what they wear in public - shapeless sweats, no make-up, a wedding ring - men still approach them. Twenty posts in, a woman finally uses the word everyone has been circling as they talk about men's aggressiveness and biology and the burden / necessity of modesty: there's that belief that wearing a short skirt will make you more likely to be raped... when in actuality the guy will rape a girl regardless of what's she's wearing... bad guys will do bad things no matter what... and good guys aren't going to be swayed because of what someone is wearing...

Partridge's post makes clear that women dress defensively, to avoid unwanted male attention in public, but also to avoid being blamed for their own assault. 
The men who leave comments about Partridge's decision to eschew leggings do not commiserate about the difficulty in choosing an attractive yet modest outfit. They do not lament the aggressiveness of women who insist on chatting them up no matter what they wear. They do not discuss biological needs, socialized gender roles, or the burden of living in a society that tells women to avoid getting raped, instead of one that insists men not rape.

Instead, a man calling himself Concerned American writes that yoga pants and leggings were never designed for comfort or exercise because their real purpose has always been to draw attention to the wearer. He claims that all women, when confronted with this ulterior motive, look "abashed." As a recovering sex addict and security guard, he finds it very distracting to see women unabashedly wearing these tight pants.

Married man BYUTE fan points out that yoga pants look good paired with a short shirt or a long one. In fact, tight pants with a long shirt is an especially sexy look since a man can then imagine all the parts hidden from view. He suggests Partridge upload a photo of herself wearing leggings with a long shirt. “... then we can judge for ourselves!”

A teenager named Jake wonders if skinny jeans on men are acceptable because he recently bought two pair for $\$ 15$.

These are not new problems for women. In 1915 Charlotte Perkins Gilman took on gender stereotypes and restrictive clothing in her novella Herland, where three men stumble upon a society inhabited only by women. Naturally, the men are stunned at how very unnatural these self-sufficient women are. No coyness of manner, no feminine charms or wiles, no "come-andfind-me element" to their personality. ${ }^{39}$ Are these women even women? the men wondered.

${ }^{39}$ Gilman 127 
Equally baffling is the women's clothing. Their dresses are functional, comfortable, and free of ornamentation, save roomy pockets. These strange creatures of Herland don't want the jeweled necklaces or colorful scarves the men have brought to woo them. In fact, the women are horrified when they hear about the restrictive and ostentatious dress of American women.

The men are horrified when gifted the same gender-neutral clothing as the women of Herland, although after donning one of the tunics, the narrator Van grudgingly concedes, "They have worked out a mighty sensible dress, I'll say that for them." 40

When Brock Turner raped Chanel Miller in 2015, she was wearing a beige cardigan. On the way to the frat party where she would meet Turner, who would later assault her unconscious body behind a dumpster, Miller's sister teased her about dressing like a librarian.

When Turner was questioned by police about the assault, he was not asked, as Miller was when reporting the rape, what he was wearing. They had both been drinking at the party; his intoxication was an excuse, hers an indictment.

In 2017 a Houston elementary school was forced to scrub from its walls a mural that advised young girls, "The more you act like a lady, the more he'll act like a gentleman."

In her 1980 essay “Throwing Like A Girl: A Phenomenology of Feminine Body Comportment, Motility and Spatiality," Iris Marion Young notes that women are more likely than men to underestimate the physical capability of their bodies because women experience their bodies

${ }^{40}$ Gilman 28 
both as a thing and as a capacity. ${ }^{41}$ Women achieve physical goals almost in spite of their body, which they both protect and drag along. In contrast, men are more likely to work with their body, to achieve something through, rather in spite of, it. ${ }^{42}$ In Young's essay, prepositions matter.

Men more often move out toward a ball in flight and confront it with their own countermotion... [Women] frequently respond to the motion of a ball coming toward us as though it were coming at us, and our immediate bodily impulse is to flee, duck, or otherwise protect ourselves from its flight. ${ }^{43}$

Spirit Week at my daughter's high school a few years ago included an "opposites day," which most of the students decided was an invitation to dress as the opposite gender. My daughter raided her younger brother's closet and left for school in athletic shorts, an oversized Dallas Cowboys t-shirt, and a baseball hat. In the pictures from opposite day, the girls were eager to show they knew how to perform male gender. To be a fourteen-year-old boy is to defiantly stare down the camera, covering your crotch with one hand while throwing up a peace sign with the other. It means confidently taking up space. Stop man-spreading, I often tell my teenaged son.

In the 1970s, German photographer Marianne Wex secretly photographed men and women in public spaces, amassing over five thousand photographs. Whether sitting on benches, lying on towels at the beach, or standing in doorways, photo after photo shows women twisting and

\footnotetext{
41 Young 145, emphasis hers

42 Young 144

43 Young 143, emphasis mine
} 
contorting their limbs, as they attempt to take up as little space as possible. Even when alone, it's hard for women to undo years and years of being told that nice girls don't sit like that.

"The space that is physically available to the feminine body is frequently of greater radius than the space which she uses and inhabits," Young notes. ${ }^{44}$ It's as if women instinctively construct an imaginary fence around their bodies, one they know is not a secure perimeter, and yet one they don’t dare breach themselves.

My daughter couldn't get over the roomy pockets on her brother's shorts. Pockets on girls' clothes, she told him, were often just for show. She listed all the things she could fit in the pockets of his shorts: pens, a phone, a hamburger.

I sometimes put bagels in my pockets, my son said.

Once before yoga class, a woman complimented my leg warmers. A man standing near us said he wished they made leg warmers for men. At least your pants have pockets, the woman said, and the man then enthused about all the things he could fit in the pockets of his yoga pants: phone, keys, wallet. The other woman and I exchanged a look before she said, I've never in my life owned a pair of yoga pants with real pockets.

In the winter, I wear my teenaged son's coat to walk the dog. The jacket does not zip over my hips, but the pockets are fleece-lined and roomy.

In 2018, Danielle Muscato asked via tweet what women would do if men had a 9 PM curfew. Women were giddy with the possibilities. They would go for night runs in just a sports bra and

44 Young 149, emphasis hers 
shorts, music blaring. They would wear the shoes they wanted, instead of ones they could run in. They would park their cars right by the door, rather than circling to find the most well-lit space in a parking lot. They would grocery shop at night and sit on the beach and oh, to live in this world. Why must this world feel as inaccessible as a fairy tale, they wondered.

I teach college now, and on the days we discuss sexual assault in class, the male students are noticeably, uncomfortably silent. If a sinkhole were to suddenly open in the classroom, I suspect they would willingly dive in. Female students are not silent, as they hold up the rape whistles on their key chains and the mace in their purses and they share the strict advice that has been handed down to them, via older women, about How To Stay Safe In The World. I don't always know the names of the latest rape prevention accessory, but I am always familiar with the advice. Never wear a ponytail at night. Always walk with your keys in your hand. Never leave your drink unattended at a party.

A man responding to Muscato's tweet was horrified to learn how many women cross dark parking lots with keys gripped between their knuckles.

Outfits worn while writing this essay: jeans without pockets in the front, a \$15 yellow flowered sundress from Old Navy, a white sweater with mauve pants, a teal dress and black leggings. The dress is knee-length and form-fitting, and the last time I wore it, I added a beige cardigan so the outfit was (to whom, exactly?) more acceptable.

A student once wrote in a paper that when he first heard the word rape, his mother told him it was something that happened to girls who dressed a certain way. He would remember this conversation years later when a high school friend revealed she was raped. He made a point of 
noting in his paper that when his friend was assaulted, she was wearing a long-sleeved shirt and a long skirt.

What was the length of your skirt? What kind of underwear were you wearing? Were you wearing underwear? Were you thinking about sex when you got dressed? Was your bra showing? Was your bra strapless? What about heels? Lipstick? Thong?

Jake the teenager's discussion about modesty - are skinny jeans on men okay? - is not the same one the women twice his age are having beneath Partridge's post. I imagine Jake as the teenaged boy bagging groceries I once asked to walk me to my car because it was dark outside (Never grocery shop alone at night, my mom told me before I left for college) and I was frightened of the man behind me in line who kept insisting he should walk me to my car, because, as he kept telling me, It's not safe out there. As I debated whether I really needed to ask a boy several years my junior to walk outside with me, I thought of an article I had recently read, about how women sometimes ignore the nagging feeling in their gut to not appear rude to the person making them uncomfortable.

How differently my son will view the world after he is asked to walk a girl to her car at night or hold her drink while she's in the bathroom.

Are skinny jeans modest or immodest? The arbitrary and unknown variables embedded in the question prevent a simple yes or no answer, Jake.

Society had a problem with $19^{\text {th }}$ century women's fashion. Doctors warned of the danger to the spine and internal organs from too tight corsets. Moralists argued the current style of women's 
clothing inflamed a man's passions and "incited immorality" by highlighting a woman's waist, hips, and bust. ${ }^{45}$ Journalists in this era often mocked women's clothing, noting with disgust that as their many petticoats skimmed the dirty streets, they hoovered up trash and god knew what else.

A fashionably attired Victorian woman struggled to lift her arms above her head, bend at the waist, exercise, get out of a carriage without a man's assistance, digest food, breathe, climb stairs, and speak for extended periods of time. Fashion turned women into helpless creatures, admired for their passivity, delicate nature, and purity.

Silly, vain women, said society.

In the 1850 s and 1860 s, a more comfortable clothing option appeared. Referred to as the reform dress or the "bloomer costume," after Amelia Bloomer published a picture of herself wearing the dress in 1851, the new dress was high-necked and modest. Rather than layers of cumbersome petticoats, the dress featured a shorter skirt with trousers underneath. The dress was first adopted by health reformers, who believed a healthy lifestyle included drinking lots of water and exercising daily, which women could not do in respectable clothing. Reform dress, also called rational dress, was designed for women by women, and it heeded doctors' warnings that the current fashion was not in the interest of women's health. What's especially notable about the influence of health reformers in dress reform was their use of science, largely considered the domain and expertise of men. Dress reformers argued that the easiest and most rational way to improve women's overall health was to modify their clothing so they could exercise and breathe without difficulty.

45 Reigel 390 
Estimating exactly how many women adopted reform dress is tricky. It appears that a number of women wore the dress in private, "to ease domestic labor," 46 which it turned out was easier to do without a corset. After enjoying the comfort of reform dress at home, a woman might eventually feel brave enough to share with close friends her secret. ${ }^{47}$ The final and most difficult step - wearing the dress in public - was certainly not taken by all women.

Reform dress eventually caught the eye of several notable feminists, including Susan B. Anthony and Elizabeth Cady Stanton, who once declared that the dress made her feel "like a captive set free from his ball and chain." 48

Women wrote into magazines about the comfort of the dress. They could garden in comfort. Lift their arms above their head. Breathe easily. Oh, to live in this world forever.

Once reform dress became associated with the feminist movement, the dress became an easy target for those who saw suffragists as unruly troublemakers bent on destroying traditional gender roles. A society where a woman's class, moral character, and appropriate gender performance was not immediately apparent via her clothing? Unthinkable. ${ }^{49}$

For many anti-dress reformers, the Bible was the ultimate authority on why women needed to abandon bloomers. Deuteronomy 22:5, for example, warns "the woman shall not wear that which pertains unto a man, neither shall a man put on a woman's garment for all who do so are an abomination unto the Lord your God."

\footnotetext{
${ }^{46}$ Mas 53

47 Mas 53

${ }^{48}$ Kesselman 498

49 Torrens 79
} 
Journalists chimed in, printing cartoons of women in short dresses, which little resembled reform dress, smoking cigars and proposing marriage to men. ${ }^{50}$ It was one thing for women to want to be comfortable while gardening in the privacy of their home. But it was all the things a woman could do while wearing reform dress in public - give speeches about equality, get in and out of a carriage without a man's assistance, travel alone - that made many men uncomfortable, outright hostile, even.

Anthony soon lamented, "The attention of my audience was fixed upon my clothes instead of my words." ${ }^{51}$ Elizabeth Cady Stanton's husband, children, and father pleaded with her to stop wearing the dress in public. ${ }^{52}$ Women who did venture out in the dress were catcalled and harassed. The modest reform dress did not call attention to a woman's waist, hips, or breasts. But there were fears that bloomers called attention to a part of the body normally hidden under layers of petticoats - a woman's legs. ${ }^{53}$ Once again, women found themselves the objects of scorn, this time for daring to dress with an eye to comfort, like a man.

In Edith Wharton's 1920 novel The Age of Innocence, the male narrator Newland Archer, while watching his wife fret over what to wear to a simple dinner with friends, suddenly understands the social importance of a woman's dress: "It's their armour," he thought, "their defence against the unknown, and their defiance of it.".54

To be cautious in breath from a corset and careful in body from a crinoline cage was to be safe. Victorian women carried the weight of their gender in their heavy skirts and corseted

\footnotetext{
50 Kesselman 501

${ }^{51}$ Kesselman 500

52 Torrens 84

53 Torrens 81

${ }^{54}$ Wharton 88
} 
breasts. They broadcast the wealth and status of their husbands via their clothes. To be uncomfortable was to be respectable; power and security lay in bodily pain.

Feminist historian Carroll Smith Rosenberg notes in Disorderly Conduct: Visions of Gender in Victorian America that the physical body is often a proxy for the social body. Social concerns are acted out on the physical body, which results in a policing of both dress and social decorum norms. ${ }^{55}$ The policies and practices of the social body, as enacted on the physical body, are then seen as the "normal" order of society, as biologically natural. ${ }^{56}$

It becomes natural, then, to ask a contemporary woman to prevent her own assault by being mindful of what she wears and how she carries herself. But what is acceptable clothing and behavior? Short skirts, beige cardigans, tight pants, revealing sweaters, lace thongs, social drinking, flirting, and staying out past dark are unacceptable.

Some women ask in response to Partridge's post if they should leave their houses wearing burlap sacks and paper bags over their heads.

Roxane Gay once wrote, "I find life rather terrifying, so I tend to dress to feel invisible and, in turn, safe. This makes me sound a little crazy, but I am not." 57

Initially, first-wave feminists were defiant in their defense of reform dress. Surely the same society that chastised women for embodying a dangerous femininity for wearing restrictive and ill-fitting clothes would not then turn around and chastise them for embodying a dangerous

\footnotetext{
55 Rosenberg 48

${ }^{56}$ Rosenberg 51

57 Women in Clothes 221
} 
masculinity by refusing to wear restrictive and ill-fitting clothes. They patiently waited for the harassment to abate.

Instead, with a sigh of defeat, they returned to their corsets and petticoats. But maybe all was not lost. A group in Boston decided to reform women's underwear. After all, that which was hidden from view would not be subjected to the same scrutiny as that which was visible. ${ }^{58}$ Women briefly returned to reform dress after the Civil War. The enterprising Mrs. Annie Jenness Miller of Evansville, Indiana attracted the notice of the press in 1888 with her dress system of legilettes and chemilettes. Legilettes were simply bloomers by another name, but this time around, women knew to avoid the "b" word. Once again, women had a decision to make. Fashionable misery or unconventional discomfort? Changing a woman's dress is more important than the right to vote, one woman declared in the newspaper.

Many women disagreed and chose the safer option of fashionable misery. In 1888, a small paragraph in the "Woman's World and Work" section of The Courier Journal notes that until women are free to swing their arms, they will never be emancipated. The unnamed author of the article pretends to be jauntily resigned to never being able to exercise, walk freely, or comfortably inflate her lungs thanks to "foolish fashion!" Beneath and around her words is a crystalline rage. It's easy to imagine she has exhausted her family and close friends with this conversation about her clothing options. But how does a person relinquish her desire for easy breath and freedom of movement?

A paragraph in the same paper explains why women rarely buy expensive artworks: “They have a quick appreciation of color harmonies when brilliant and decorative, but seldom indulge in an analysis of either motive or meaning."

\footnotetext{
${ }^{58}$ Kesselman 508
} 
Of the three men who stumble upon Herland, only one of them, a hard-headed man named Terry, refuses to see the women as equals. Terry continues to insist that women are pretty objects to be admired, no more consequential than the baubles and feathers they affix to their clothing. It's enraging to him that his male companions not only respect but often defer to the unadorned, unfeminine women of Herland. When the narrator Van falls in love with one of the women, he is forced to re-think societal and gender notions he had once considered immutable:

This led me very promptly to the conviction that that those "feminine charms" we are so fond of are not feminine at all, but mere reflected masculinity - developed to please us because they had to please us, and in no way essential to the real fulfillment of their great process. ${ }^{59}$

Terry has no such epiphany. Instead, he becomes increasingly irate with his wife Alima who refuses to submit to him. He tells his friends, "There never was a woman yet that did not enjoy being mastered." 60 Or as Van notes, "The things [Terry] learned didn’t help him a heap in Herland. His idea was To Take - he thought that was the way. He thought, he honestly believed, that women like it." 61 With this in mind, Terry sneaks into Alima's room one night, intent upon claiming with force what he believes he is owed.

Even though the women of Herland aren't naturally fearful of men, Alima's concern over her husband's erratic behavior prompted her to ask several women to hide in an adjoining room. Terry's attempt to rape his wife ends with him anaesthetized, hands bound behind his back. When he's hauled before the court to answer for his behavior, he asserts that the women of

59 Gilman 60

60 Gilman 128, emphasis hers

${ }^{61}$ Gilman 130 
Herland, being “bloodless, sexless creatures," don't understand a man's needs. The women of the court dispassionately listen to his hysterical ranting before banishing him forever from Herland.

I do not recommend reading a novella about a land inhabited entirely by peaceful, intelligent women, a land where rape is punished and "boys will be boys" is never used as a defense, when, for the second time in your life, a woman reluctantly accuses a man of sexual misconduct and, days later, he is confirmed as a Supreme Court justice.

A few summers ago, as I strolled home alone, enjoying the warn weather and my favorite sundress, a man shouted from his car, Are you wearing anything under that dress?! He slowed down his car to yell this, but no one on the crowded sidewalk with me reacted at all, and I walked home with a burning face and a crystalline anger.

A Victorian etiquette handbook warned women, "Allowing a dress to trail on the street is in exceedingly bad taste. Such a street crossing calls forth criticism and contempt from the more sensible people. A true lady will go quietly and unobtrusively about her business when on the street, never seeking to attract the attention of the opposite sex." This same handbook told women to stop sucking on their parasols.

Strapless bras are not corsets, but the last time I wore one, I nearly cried in relief when I took it off at the end of the day. Seven petticoats must have weighed less than harassment on the street. 
A 2016 Bloomingdale's ad for Christmas clothes features an attractive man and woman. "Spike your best friend's eggnog when they're not looking," is in all caps at the top of the ad, the words best friend in bold. The woman is laughing, her head turned away, while her friend eyes her exposed neck. The man ogling his beautiful best friend is the man she trusts to watch her drink when she is in the restroom. It never once crossed my mind that my best friend in college would do anything other than hold my plastic cup of cheap wine when I was in the bathroom.

In Wex's photos, women keep their arms close to their body. Young notes that in a society more permissive when it comes to touching women than men, this encircling of the body keeps others at a distance and wards off unwanted invasions. ${ }^{62}$ Women are always aware, even if the woman in the Bloomingdale's ad was not, of being the object of someone's gaze.

If anyone is be asked What were you wearing? shouldn't it be the person accused of rape, rather than the survivor?

A friend once told me that she is close to the age of being sexually invisible. Freedom, I immediately thought. I told a different friend about this and she looked incredulous. I don't think a woman is ever sexually invisible, she said.

62 Young 154 
In 2018, a 27-year-old Irish man was acquitted of rape after his defense attorney Elizabeth O'Connell said about the man's teenaged victim, "You have to look at the way she was dressed. She was wearing a thong with a lace front." ${ }^{33}$

After the man's acquittal, Irish women took to the streets in protest. They wore thongs on their heads, strung them from lampposts, and taped them to posters. My underwear is not your consent, women said. That which is hidden from view is not yours.

Over and over again, we are told that our short skirts and leggings and underwear and kindness and refusals and indifference provoke violent lust. $19^{\text {th }}$ century fears about a woman's clothing and her inevitable seduction have been updated for the $21^{\text {st }}$ century to fears about a woman's clothing and her inevitable rape. Women exchanged a corset and petticoats for pants and shorter skirts, yet the dance of respectability - act like a lady so he'll behave like a gentleman - is unchanged.

The anger women feel is inherited, handed down generation to generation. Every decade it calcifies and grows heavier, as exhausting as seven petticoats. It is a daily fight to not let this anger, and the helplessness it engenders, bend our spines and force us indoors by 9 PM.

Once while wearing the $\$ 15$ yellow sundress from Old Navy, a group of women honked and shouted from their car windows as I walked down the street, We love your dress!

${ }^{63}$ Ingber 


\section{REFERENCES}

Carnes, Mark C. ed. Novel History: Historians and Novelists Confront America's Past (and Each Other). Simon \& Schuster, 2001.

Cooper, Katherine and Emma Short, eds. The Female Figure in Contemporary Historical Fiction. Palgrave Macmillan, 2012.

Crane, Diana. "Clothing Behavior as Non-Verbal Resistance: Marginal Women and Alternative Dress in the Nineteenth Century." Fashion Theory, vol. 3, issue 2, 1999, pp.241-268.

"Dress Reform: The Progress of the Movement Looking to More Healthful Clothing For Women and Girls." The Courier Journal. 29 May 1887, p.13.

Friedman, Ellen G. and Miriam Fuchs, eds. Breaking the Sequence: Women's Experimental Fiction. Princeton University Press, 1989.

Gallagher, Catherine. “Telling It Like It Wasn't.” Pacific Coast Philology, Vol. 45, 2010, pp. 1225.

Hill, Professor Thomas E. The Essential Handbook of Victorian Etiquette. Bluewood Books, 1994 (adapted from material written and published by Professor Thomas E. Hill between 1873 and 1890).

Ingber, Sasha. “\#ThisIsNotConsent: Protests in Ireland After Thong Underwear Cited in Rape Trial."NPR, 16 Nov. 2018.

Kesselman, Amy. "The 'Freedom Suit': Feminism and Dress Reform in the United States, 18481875." Gender and Society, vol. 5, no. 4, 1991, pp. 495-510.

Kitchen, Judith. "Grounding the Lyric Essay." Fourth Genre: Explorations in Nonfiction, vol. 13, no. 2, 2011, pp. 115-121.

Mas, Catherine. "She Wears the Pants: The Reform Dress as Technology in NineteenthCentury America.” Technology and Culture, vol. 58, no. 1, 2017, pp.35-66.

Mulvey, Laura. "Visual Pleasure and Narrative Cinema." Film Theory and Criticism: Introductory Readings. Eds. Leo Braudy and Marshall Cohen, Oxford UP, 1999. Partridge, Veronica. "Why I Chose to No Longer Wear Leggings." Veronica. A heart for homemaking. 5 Jan. 2015.

Petrov, Julia. “"A Strong-Minded American Lady': Bloomerism in Texts and Images.” Fashion 
Theory, vol. 20, issue 4, 2015, pp.381-413.

Phillips, Mark Salber. "Distance and Historical Representation." History Workshop Journal, No. 57 (Spring 2004), pp. 123-141.

Riegel, Robert. “Women's Clothes and Women's Rights.” American Quarterly, vol. 15, no. 3, 1963, pp.390-401.

Rosenberg, Carroll Smith. Disorderly Conduct: Visions of Gender in Victorian America. Knopf, 1985.

Sinor, Jennifer. "Deserting the Narrative Line: Teaching the Braided Form." Teaching English in the Two-Year College, vol. 42, no. 2, 2014, pp. 188-196.

Solnit, Rebecca. Men Explain Things to Me. Haymarket Books, 2014.

Strange, Lisa S. "Dress reform and the feminine ideal: Elizabeth Cady Stanton and the 'Coming Girl." Southern Journal of Communication, vol. 68, no. 1, 2002, pp.1-13.

Torrens, Kathleen M. "Fashion as Argument: Nineteenth-Century Dress Reform." Argumentation and Advocacy, vol. 36, Fall 1999, pp.77-87.

Tredinnick, Mark. "The Lyric Stance: Voice, Place and the Lyric Essay.” Island 126 (2011), Web.

Wharton, Edith. The Age of Innocence. Black and White Classics, 2015.

"Women and Art." The Courier Journal. 25 March 1888, p. 17.

Women in Clothes. Edited by Sheila Heti, Heidi Julvatis, and Leanne Shapton. Blue Rider Press: Penguin Books, 2014.

Woolf, Virginia. A Room of One's Own. Arcturus Publishing Limited, 2018.

Young, Iris Marion. "Throwing Like A Girl: A Phenomenology of Feminine Body Comportment, Motility and Spatiality." Human Studies, vol. 3, 1980, pp.137-156. 


\section{CURRICULUM VITA}

Kelly E. Hill

(512) 565-7249

kelly.morris.3@louisville.edu

Comparative Humanities Department

1257 Royal Ave.

Bingham Humanities 212

Louisville, KY 40204

2216 S. $1^{\text {st }}$ Street

University of Louisville

Louisville, KY 40292

\section{EDUCATION}

Ph.D. Comparative Humanities - University of Louisville - Louisville, KY - April 2021

Creative Dissertation: A Home For Fallen Women: A Historical Novel

Critical Dissertation: "But What Was She Wearing?: An Examination of $19^{\text {th }}$ Century Dress Reform and $21^{\text {st }}$ Century Rape Culture"

Committee Members: Deborah Lutz (Director), Susan Ryan, Nancy Theriot, and Pamela Beattie (outside reader)

MFA in Writing - Spalding University - Louisville, KY- 2013

Creative Thesis: Unsung Lullabies: A Novel

Bachelor of Arts in Spanish - University of Texas at Austin - Austin, TX - 2000

Graduated Phi Beta Kappa with honors in Spanish

\section{PUBLICATIONS}

Creative Publications - Short Stories

- Hill, Kelly. “At the Airport.” The Conium Review, Vol. 9, Winter 2020-21.

- Morris, Kelly. “The Bearded Loon.” upstreet magazine, issue 13, Summer 2017.

- Morris, Kelly. “The Favor.” Epiphany Literary Journal, Beyond the Pale Unknown issue, Fall/Winter 2016.

- Morris, Kelly. “At the Zoo.” Gravel Magazine, November 2015.

- Morris, Kelly. “Dream Club.” Yemassee Journal, vol. 22, issue 2, Fall 2015.

- Morris, Kelly. "Just don’t ask us what we do all day.” The Los Angeles Review, vol. 17, Spring 2015.

- Morris, Kelly. “How These Things Start.” Drafthorse Literary Journal, issue 5, Winter 2014.

- Morris, Kelly. “The Neighbor.” Superstition Review, issue 14, November 2014. 
- Morris, Kelly. “In the Right Hands.” Writing Tomorrow, vol. 3, issue 1, October 2014.

- Morris, Kelly. "Butterflies.” The Madison Review, vol. 36, Fall 2014.

- Morris, Kelly. “The Ex.” Per Contra, issue 32, Summer 2014.

- Morris, Kelly. “Dear Ellen.” Temenos Journal, Balancing Act issue, Spring 2014.

- Morris, Kelly. “End of Days.” Red Savina Review, vol. 2, issue 1, Spring 2014.

- Morris, Kelly. “Why Are We Getting Married?” SunDog Lit, issue 4, November 2013.

- Morris, Kelly. “You, the Ex, and the Neighbor.” Spry Literary Journal, issue 2, Summer 2013.

- Morris, Kelly. "You Never Asked." The $9^{\text {th }}$ Annual Writer's Digest Short Short Story Competition Collection, Writer's Digest Magazine, 2009.

\section{SCHOLARLY and MAGAZINE PUBLICATIONS}

- DailyArt Magazine Contributing Staff Writer, April - present

Wrote and edited art articles with a focus on feminist art, forgotten female artists, and representations of the female body.

- Hill, Kelly. “Now It Is All About to Happen.” Blood Orange Review. Winter 2019.

- Morris, Kelly. "The Exile's Epic Path to Healing: Authorial Intrusion in Purgatorio and Omeros." Altre Modernità/Other Modernities. University of Milan. Nov. 2017.

- Morris, Kelly. “The Home for Friendless Women.” The Filson. Vol. 17, No. 2, Summer 2017.

\section{AUTHOR INTERVIEWS}

- Hill, Kelly. “Authors Talk” contributor, Superstition Review, Oct. 2018.

- Hill, Kelly. "Decline/Accept interview," Carve Magazine, Summer 2018.

- Morris, Kelly. "7 Questions with Kelly Morris," Yemassee Journal, September 2015.

- Morris, Kelly. "Behind the Words: Kelly Morris," Spry Literary Journal: Briefs, August 2013.

\section{AWARDS}

- $\quad$ Outstanding Graduate in Humanities Award, Spring 2021

- Graduate research assistantship to the Jewish Studies Program, Fall 2019 - Spring 2021

- Finalist in Creative Nonfiction Contests

Bellingham Review - "But What Was She Wearing?" 2020

American Literary Review - "But What Was She Wearing?" 2019

Blood Orange Review - "Now It Is All About To Happen” 2019

International Literary Awards - "A Mighty Sensible Dress" 2019

- Graduate Teaching Assistantship Award, 2017-present

- Commonwealth Center for Humanities and Society Internship at the Filson Historical Society, 2017 
- Pushcart Nominee (“Dream Club”), 2015

- Winner of Yemassee Journal's William Richey Short Fiction Contest ("Dream Club"), 2015

- Finalist in Writer's League of Texas Mainstream Fiction Manuscript Contest

Unsung Lullabies, 2014

Since God Was a Boy, 2013

\section{ACADEMIC EMPLOYMENT}

\section{Graduate Teaching Assistant, Comparative Humanities}

University of Louisville, Fall 2017 - Spring 2021

- Taught 7 sections (traditional, online, and hybrid) of HUM 151 - Creativity and the Arts

- Taught 9 sections (traditional) of HUM 152 - Cultures of America

\section{Adjunct Instructor, English}

Spalding University, Fall 2020

- Taught 1 section (online asynchronous) of college writing with emphasis on research process - ENG 110

\section{Adjunct Instructor, Discernment and Discourse}

Southern Methodist University, Dallas, TX, Fall 2015 - Spring 2016

- Taught 4 sections (traditional) of introductory writing course - DISC 1312

- Taught 2 sections (traditional) of introductory writing course with emphasis on research process - DISC 1313

\section{LECTURES AND PRESENTATIONS}

- "A Home for Friendless Women: Utilizing the Newspaper in Research and the Classroom." AHA Virtual Research Series 2021. Louisville, KY

- "Fallen Girls and Working Women: Prostitution in the $19^{\text {th }}$ Century." The Conrad-Caldwell House Lecture Series 2020. Louisville, KY.

- “But What Was She Wearing?” The Louisville Conference on Literature and Culture Since 1900, Unruly Women Critical Panel 2020. Louisville, KY.

- "Now It Is All About to Happen.” The Louisville Conference on Literature and Culture Since 1900, Creative Panel 2020. Louisville, KY.

- "Representations of Gender in $19^{\text {th }}$ Century Art." University of Louisville Guest Lecturer 2020. Louisville, $\mathrm{KY}$.

- “The Exile's Epic Path to Healing: Authorial Intrusion in Purgatorio and Omeros." The Louisville Conference on Literature and Culture Since 1900, Walcott and Dante Critical Panel 2019. Louisville, KY.

- “An Incomplete List of Weddings.” The Louisville Conference on Literature and Culture Since 1900, Creative Panel 2019. Louisville, KY.

- "The Male Gaze: Examining the Normalization of Violence Against Women in Media and Advertising." University of Louisville Guest Lecturer 2019. Louisville, KY.

- "Writing a Sex Scene: How Not to Screw it Up." Carnegie Center Fiction Workshop 2018. Lexington, KY. and Winter Wheat Conference 2015. Bowling Green, $\mathrm{OH}$.

- "The End is the Beginning." Carnegie Center Fiction Workshop 2018. Lexington, KY. 
- “An Incomplete List of Weddings.” River City Revue Reading Series 2018. Louisville, KY.

- "Beach Clean-Up Day." Flying Out Loud Reading Series 2018. Louisville, KY.

- "Dream Club.” River City Revue Reading Series 2017. Louisville, KY.

- “Writing a Novel during NaNoWriMo.” Dallas Public Library 2015. Dallas, TX.

- "Playing Around: Discovering Stories Through Non-Traditional Forms." Winter Wheat Conference 2015. Bowling Green, $\mathrm{OH}$.

\section{TUTORING EXPERIENCE}

Writing Tutor, University of Louisville Athletic Department, Oct. 2016 - June 2017

- Provided one-on-one tutoring for student athletes during football study hall, specifically with writing and Humanities assignments

Writing Tutor, Southern Methodist University, Aug. 2015 - July 2016

- Provided one-on-one tutoring for student athletes, specifically with writing and English assignments

\section{ACADEMIC SERVICE}

\section{SERVICE TO THE PROFESSION}

\section{Teaching Workshop Participant}

Delphi U, 2019

- Created a fully online course for HUM 152

- Learned about interactive online teaching tools found on BB, including SoftChalk, Panopto, BB

Collaborate, and Discussion boards

Active Learning Series, 2017 - 2018

- Created an assignment for the HUM 105 course

- Learned new ideas for incorporating both technology and active learning activities into the classroom

\section{Conference Volunteer}

The Louisville Conference on Literature and Culture Since 1900, 2017 and 2018

- Assisted in registration and chaired creative session panel

The Kentucky Women's Book Festival, 2019

- Worked registration table and assisted with book signings and lunch

\section{Post-Graduate Residency Spring Assistantship}

Spalding University's low-residency MFA Program, 2014 - present

- Assisted in day-to-day operations of low-residency program, held bi-annually in November and May

\section{Editorial Reader}

Writer's Block Prize in Fiction, 2019

- Reviewed submissions for the Writer's Block Prize in Fiction and voted on their literary merit

Spry Literary Journal, 2013 - 2015

- Reviewed and voted on submitted fiction submissions to the journal

- Interviewed published authors for the journal's blog Briefs

The Louisville Review, 2013

- Reviewed and voted on submitted fiction, non-fiction, and poetry submissions to the magazine 
Secretary - Association for Humanities Academics (AHA), 2018 - 2019

- Collaborated with graduate students in planning academic and professional events

Humanities Representative - Graduate School of Natural Arts and Sciences (GNAS), Fall 2017 - Spring 2019

- Attended monthly meetings to ensure the Humanities Department remained eligible for travel and research funding

- Worked on scholarship committee and review/vote on incoming research fund applications

- Assisted with Abstract Writing Workshop for graduate students in collaboration with the Writing Center

Peer Mentor - University of Louisville, 2017 - present

- Provided mentorship to Ph.D. students during visitation and through their first year 